\title{
SORÇÃO DE 2,4-D E DIURON NOS AGREGADOS ORGANOMINERAIS DE LATOSSOLOS EM FUNÇÃO DOS CONTEÚDOS DE MATÉRIA ORGÂNICA E DE ÁGUA
}

\author{
WADSON SEBASTIÃO DUARTE DA ROCHA
}

\begin{abstract}
Tese apresentada à Escola Superior de Agricultura "Luiz de Queiroz", Universidade de São Paulo, para obtenção do título de Doutor em Agronomia, Área de Concentração: Solos e Nutrição de Plantas.
\end{abstract}

PIRACICABA

Estado de São Paulo - Brasil

Junho - 2003 


\title{
SORÇÃO DE 2,4-D E DIURON NOS AGREGADOS ORGANOMINERAIS DE LATOSSOLOS EM FUNÇÃO DOS CONTEÚDOS DE MATÉRIA ORGÂNICA E DE ÁGUA
}

\author{
WADSON SEBASTIÃO DUARTE DA ROCHA
}

Engenheiro Agrônomo

Orientador: Prof. Dr. LUÍS REYNALDO FERRACCIÚ ALLEONI

Tese apresentada à Escola Superior de Agricultura "Luiz de Queiroz", Universidade de São Paulo, para obtenção do título de Doutor em Agronomia, Área de Concentração: Solos e Nutrição de Plantas.

PIRACICABA

Estado de São Paulo - Brasil

Junho - 2003 


\title{
Dados Internacionais de Catalogação na Publicação (CIP)
} DIVISÃO DE BIBLIOTECA E DOCUMENTAÇÃO - ESALQ/USP

\begin{abstract}
Rocha, Wadson Sebastião Duarte da
Sorção de 2,4-D e Diuron nosagregadosorganominera is de latossolos em função dosconteúdo de matéria orgânica e de água / Wadson
\end{abstract} Sebastiã o Duarte da Rocha. - - Piracicaba, 2003.

$75 \mathrm{p}$.

Tese (doutorado) - Escola Superior de Agricultura Luiz de Queiroz, 2003. Bibliografia.

1. Física do solo 2. Herbícidas 3. Latossolo 4. Matéria orgânica 5. Microbiologia do solo 6. Minerologia do solo 7. Sorção 8. Umidade do solo I. Título

CDD 632.954 


\section{DEDICO}

À minha amada esposa Adriana Fonseca Côrtes, à minha mãe, Rita de Cássia Duarte da Rocha, (In memorian), ao meu pai, Antonio Alves da Rocha, e meus irmãos, Wanderson Duarte da Rocha, Wesley Duarte da Rocha e Welca Duarte da Rocha. 


\section{AGRADECIMENTOS}

Agradeço a todos que de alguma forma contribuíram com esta tese e, especialmente:

Ao amigo e Professor Dr. Luís Reynaldo Ferracciú Alleoni, pela confiança, pela oportunidade, pela orientação dedicada e pelo companheirismo.

À amiga Dr. Jussara Borges Regitano por acreditar no meu potencial, pelo aprendizado, e pelo companheirismo nos momentos difíceis.

Ao Dr. Valdemar Luis Tornisielo, pela amizade e disponibilidade na solução de problemas técnicos.

Ao Dr. Ladislau Martin-Neto e a Dr. Débora Milori, pela amizade e pela disponibilidade para realização das análises e discussão dos resultados.

À amiga e técnica de laboratório Rosângela Aparecida De Gaspari, à amiga Luciana Marchese e ao amigo Carlos Alberto Dorelli e a todos os técnicos, funcionários, estudantes e estagiários da Seção de Ecotoxicologia do Centro de Energia Nuclear na Agricultura (CENA/USP).

À amiga Nancy C. Amaral, à Bete e ao Luiz Silva e a todos os funcionários do Departamento de Solos e Nutrição de Plantas da Escola Superior de Agricultura “Luiz de Queiroz” (ESALQ/USP).

À Embrapa Instrumentação Agropecuária, São Carlos/SP, por disponibilizar as instalações de pesquisa.

Ao Departamento de Solos e Nutrição de Plantas pela oportunidade de ingresso no curso de Pós-Graduação. 
Aos amigos, Fábio Prata, Fernando Zambrosi, Márcio R. Soares, Michel A. Cambri, Robson R.M. Barizon, Silvino G. Moreira e Vanessa C. do Brasil Cardinali, pelas contribuições na realização desta pesquisa e pelo companheirismo.

Em especial à Adriana Fonseca Côrtes, pela ajuda nas análises laboratoriais, pelo estímulo, pela compreensão, pela dedicação e amor.

À Escola Superior de Agricultura "Luiz de Queiroz" e ao Centro de Energia Nuclear na Agricultura da USP.

À FAPESP, pelo suporte financeiro e também ao CNPq pela concessão da Bolsa de Estudo nos primeiros 6 meses. 


\section{SUMÁRIO}

Página

RESUMO ............................................................................ viii

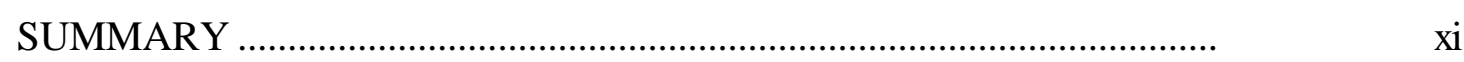

1 INTRODUÇÃO ......................................................................... 1

2 REVISÃO DE LITERATURA …........................................................

$2.1 \quad$ Herbicida ...............................................................................

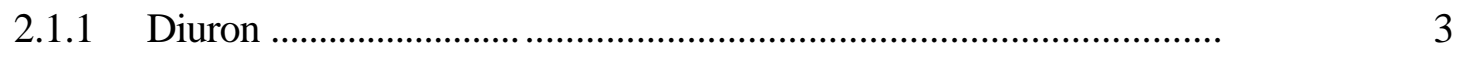

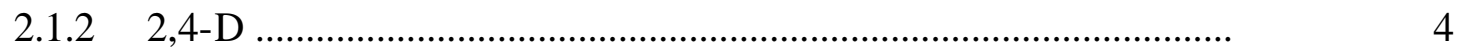

2.2 Fracionamento físico e carbono orgânico .............................................

2.3 Caracterização da fração orgânica ....................................................... 8

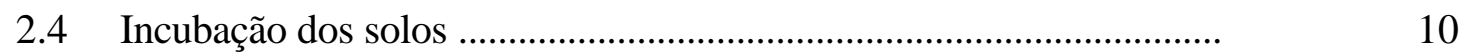

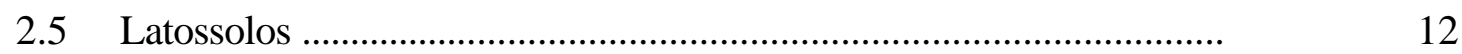

3 MATERIAL E MÉTODOS ............................................................... 14

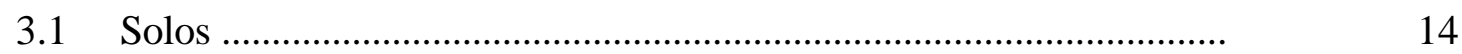

3.2 Análises químicas, físicas e mineralógicas ........................................... 14

3.2.1 Análises químicas ...................................................................... 14

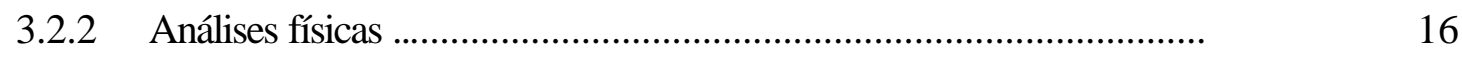

3.2.3 Análises mineralógica qualitativa ...................................................... 16

3.3 Fracionamento físico e determinação do carbono orgânico ................... 16

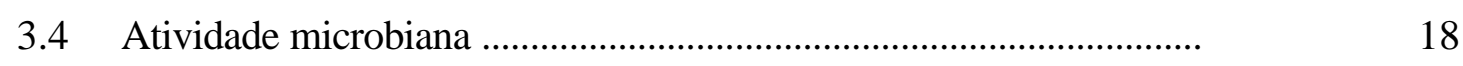

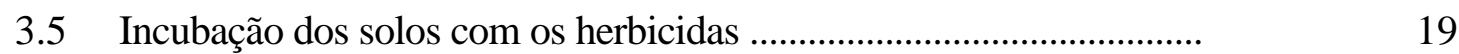


3.5.1 LAd a $75 \%$ da capacidade de campo ............................................... 19

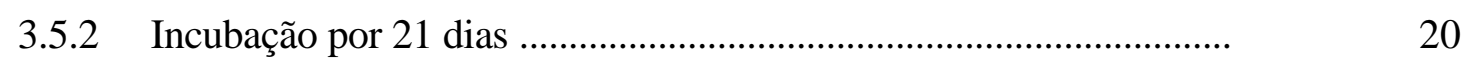

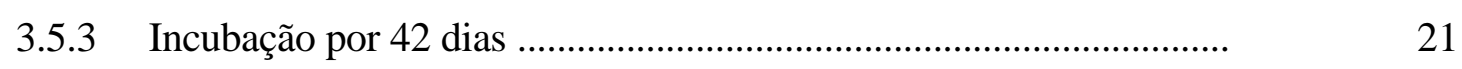

3.5.4 Determinação do grau de humificação ................................................. 23

4 RESULTADOS E DISCUSSÃO ....................................................... 24

$4.1 \quad$ Atributos dos solos .................................................................... 24

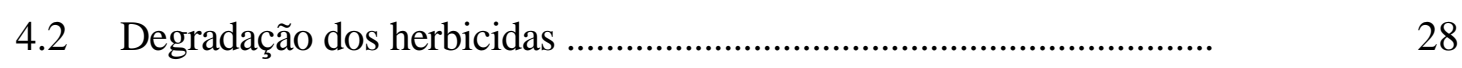

4.3 Extração e sorção dos herbicidas ........................................................ 32

4.4 Fracionamento físico ................................................................. 34

4.4.1 Carbono orgânico nos agregados organominerais ............................. 36

4.4.2 Sorção dos herbicidas nos agregados organominerais ....................... 38

4.5 Grau de humificação ..................................................................... 52

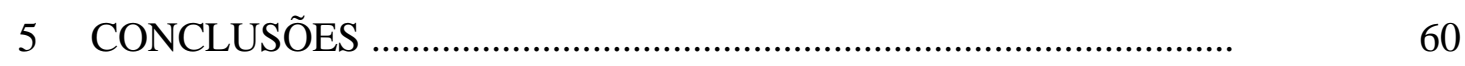

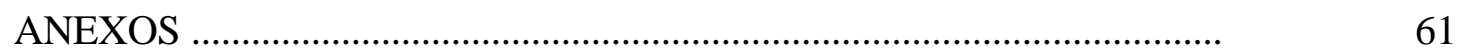

REFERÊNCIAS BIBLIOGRÁFICAS .................................................... 64 


\title{
SORÇÃO DE 2,4-D E DIURON NOS AGREGADOS ORGANOMINERAIS \\ DE LATOSSOLOS EM FUNÇÃO DOS CONTEÚDOS DE MATÉRIA \\ ORGÂNICA E DE ÁGUA
}

\author{
Autor: WADSON SEBASTIÃO DUARTE DA ROCHA \\ Orientador: Prof. Dr. LUÍS REYNALDO FERRACCIÚ ALLEONI
}

\section{RESUMO}

A dinâmica dos herbicidas no solo é influenciada pela umidade e pela quantidade e qualidade da matéria orgânica, que são variáveis nos agregados organominerais. Os objetivos foram avaliar a influência do grau de umidade na mineralização e sorção do 2,4-D (ácido fraco) e Diuron (não ionizável), em quatro latossolos com diferentes quantidades de matéria orgânica do solo (M.O.S.), avaliar a influência do tamanho do agregado (> 150, 54 - 150, 21 - 53, $2-20$ e $<2 \mu \mathrm{m})$ na sorção dos herbicidas e determinar o grau de humificação para explicar possíveis diferenças na sorção. Foram utilizadas amostras superficiais $(0 \quad-\quad 0,2$ m) de um Latossolo Amarelo distrófico (LAd) (Piracicaba/SP), de um Latossolo Amarelo ácrico (LAw) (Uberlândia/MG), de um Latossolo Vermelho ácrico (LVw-1) (Uberlândia/MG) e de um Latossolo Vermelho ácrico (LVw-2) (Canoinhas/SC). Foram determinados os valores de $\mathrm{pH}$ (em $\mathrm{H}_{2} \mathrm{O}, \mathrm{KCl} 1,0 \mathrm{~mol} \mathrm{~L}{ }^{-1}$ e $\mathrm{CaCl}_{2}$ 0,01 mol L ${ }^{-1}$ ), a quantidade de M.O.S., de 
fósforo, de $\mathrm{K}^{+}$, de $\mathrm{Ca}^{2+}$, de $\mathrm{Mg}^{2+}$, de $\mathrm{Al}^{3+}$ e estimada a soma $\mathrm{H}+\mathrm{Al}$. Os óxidos de ferro, de alumínio e de silício foram quantificados após extração com ácido sulfúrico, os óxidos de ferro "livre" e mal cristalinizado também foi determinado e a análise granulométrica foi efetuada pelo método do densímetro, sendo quantificada também a argila dispersa em água (ADA). Foi determinada a mineralogia por difração de raio-X. Foram quantificadas as frações organominerais dos solos. Foram dispersos $40 \mathrm{~g}$ de solo em $160 \mathrm{~mL}$ de água destilada, que foram agitados a 160 agitações $\min ^{-1}$ por $16 \mathrm{~h}$ e sonificada por 15 min. Após disperso, o solo foi peneirado para separar os agregados $>150 \mu \mathrm{m}$ e entre 53 e $150 \mu \mathrm{m}$. Os agregados menores que $53 \mu \mathrm{m}$ foram separados por sedimentação. Foi determinado o carbono orgânico dos agregados e do solo por combustão. A atividade microbiana dos solos foi determinada pelo método da radiorespirometria. Amostras dos solos foram incubadas com ${ }^{14} \mathrm{C}-2,4-\mathrm{D}$ e ${ }^{14} \mathrm{C}-$ diuron por 42 dias umedecidas a 25,50 e $75 \%$ da capacidade de campo em sala climatizada semi-escura a $22 \pm 2{ }^{\circ} \mathrm{C}$, após foram realizadas três extrações com $\mathrm{CaCl}_{2}$ 0,01 mol $\mathrm{L}^{-1}$. O solo foi então fracionado após oxidação para determinar o os herbicidas sorvidos no solo e, posteriormente nos diferentes agregados. O grau de humificação das amostras foi determinado por fluorescência. A mineralização do 2,4-D foi de $62 \%$ no LAd a $75 \%$ da capacidade de campo. A difusão foi responsável pela sorção dos herbicidas. O 2,4-D foi menos sorvido no LAd, que tinha maior $\mathrm{pH}$ e menor quantidade de M.O.S.. Os solos apresentaram maior quantidade de agregados $>150 \mu \mathrm{m}$. Os agregados organominerais de diâmetro menores que $53 \mu \mathrm{m}$ apresentaram maior acúmulo de carbono. A exceção do LAd, os herbicidas foram mais sorvidos pelos agregados maiores que $53 \mu \mathrm{m}$. A sorção só aumentou nos agregados menores que $53 \mu \mathrm{m}$, quando a amostra foi incubada a $75 \%$ da capacidade de campo. Porém, no caso do diuron, isto só foi verificado no LAw e LVw-1. As sucessivas extrações alteraram a estabilidade dos agregados. $\mathrm{O}$ 
LAd que se localiza em uma área de cultivo tem maior grau de humificação que o LVw-2 localizado em uma área não cultivada. Os agregados de diâmetro entre 53 e $150 \mu \mathrm{m}$, foram os que tiveram maior grau de humificação nos solos. 


\title{
2,4-D AND DIURON SORPTION IN OXISOLS ORGANIC-MINERAL AGGREGATES AS A FUNCTION OF ORGANIC MATTER AND WATER CONTENTS
}

\author{
Author: WADSON SEBASTIÃO DUARTE DA ROCHA \\ Adviser: Prof. Dr. LUÍS REYNALDO FERRACCIÚ ALLEONI
}

\section{SUMMARY}

The dynamic of herbicides in soils is influenced by soil moisture and organic matter contents and also by their quality, which are variable in the organic-mineral aggregates of the soils. The aims of this research were to evaluate the effects of soil moisture on the mineralization and sorption of the herbicides 2,4-D (weak acid) and diuron (non-ionic), in four Oxisols with different contents of soil organic matter (SOM), as well as to evaluate the influence of aggregate sizes ( $>150,54-150,21-53,2-20$ and $<2 \mu \mathrm{m}$ ) and degree of humification in the sorption of these herbicides. Surface samples $(0-$ $0.2 \mathrm{~m}$ ) of one Xanthic Hapludox (LAd, from Piracicaba/SP), one Xanthic Acrudox (LAw, from Uberlândia/MG), and two Anionic Acrudox (LVw-1 from Uberlândia/MG and LVw-2 from Canoinhas/SC) were collected. SOM, phosphorus, $\mathrm{K}^{+}, \mathrm{Ca}^{2+}$, and $\mathrm{Mg}^{2+}$ contents and $\mathrm{pH}$ values (in $\mathrm{H}_{2} \mathrm{O}$, in $\mathrm{KCl} 1.0 \mathrm{~mol}$ $\mathrm{L}^{-1}$ and in $\mathrm{CaCl}_{2} 0.01 \mathrm{~mol} \mathrm{~L}^{-1}$ ) were measured, whereas $\mathrm{H}+\mathrm{Al}$ was calculated. $\mathrm{Fe}$, 
$\mathrm{Al}$, and $\mathrm{Si}$ oxides were quantified after soil extraction with $\mathrm{H}_{2} \mathrm{SO}_{4}$. Free and amorphous Fe oxides were determined by $\mathrm{DCB}$ and oxalate method, respectively. Granulometric analysis and water dispersed clay (WDC) were quantified by the densimeter method. The mineralogy was evaluated by X-ray diffraction. In order to quantify soil organic-mineral aggregates, $40 \mathrm{~g}$ of soil was added to $160 \mathrm{~mL}$ of distilled water in centrifuge tubes, which were shaken for $16 \mathrm{~h}$ at $160 \mathrm{rpm}$ and sonicated for $15 \mathrm{~min}$ at $240 \mathrm{~W}$. The aggregates > 150 and $53-150 \mu \mathrm{m}$ were obtained by sieving, whereas the aggregates $<53 \mu \mathrm{m}$ were obtained by sedimentation. Soil and aggregate organic carbon contents were obtained by combustion. The soil microbial activity was obtained by the radiorespirometry method. Soils were incubated with ${ }^{14} \mathrm{C}-2,4-\mathrm{D}$ and ${ }^{14} \mathrm{C}$-diuron, for $42 \mathrm{~d}$ at 25,50 and $75 \%$ of the field capacity and remained in a semi-dark room at controlled temperature of $22 \pm 2{ }^{\circ} \mathrm{C}$. Then, the pesticides were extracted three times with $\mathrm{CaCh}_{2} 0.01 \mathrm{~mol} \mathrm{~L}^{-1}$ and, afterwards, the soil samples were fractionated in order to quantify the amount of herbicides in the aggregates. In these, the degree of humification was obtained by fluorescence. Diffusion markedly affected the herbicides sorption. For example, 2,4-D mineralization was $62 \%$ on LAd only at $75 \%$ field capacity. As expected, 2,4-D was less sorbed on LAd that had higher $\mathrm{pH}$ and lower SOM content. In general, the soils presented higher amounts of aggregates $>150 \mu \mathrm{m}$. The organic-mineral aggregates $<53 \mu \mathrm{m}$ presented higher organic carbon content. However, the herbicides were more sorbed in the aggregates $>53 \mu \mathrm{m}$, except for LAd. When the soil were at $75 \%$ of the field capacity, the sorption increased in the aggregates $<53 \mu \mathrm{m}$ for $2,4-\mathrm{D}$, but it was only verified for $\mathrm{LAw}$ and $\mathrm{LVw}-1$ for diuron. The successive extractions altered the aggregate stability. The LAd located in a tilled area had higher degree of humification than the LVw-2 located in a non-tilled area. The soil aggregates between 53 and $150 \mu \mathrm{m}$ presented higher degree of humification. 


\section{INTRODUÇÃO}

No intuito de aumentar a produção o uso dos pesticidas se tornou muito importante no sistema agrícola moderno. A dinâmica de moléculas orgânicas no solo é influenciada, principalmente, pela matéria orgânica do solo (M.O.S.). Por isso, é fundamental conhecer suas características em associação com a fração mineral, pois são responsáveis pela sorção de pesticidas.

$\mathrm{Na}$ maioria dos trabalhos, o estudo da M.O.S. e suas interações com pesticidas são feitos numa só fração física, menor que $2 \mathrm{~mm}$. Pouca informação da natureza e das características da M.O.S. associada com partículas do solo de diferentes está disponível na literatura, principalmente em solos tropicais. Porém, a quantidade de carbono, a composição e o grau de humificação do material orgânico são distintos nas diferentes frações físicas, o que pode ocasionar variada sorção de herbicidas. As partículas menores normalmente apresentam maior superfície específica e maior conteúdo de carbono orgânico. Desta forma, o coeficiente de sorção de pesticidas nestas frações chega a ser muitas vezes maior que na amostra de solo não fracionada. Portanto, é importante determinar a sorção de herbicidas nas diferentes frações físicas do solo.

Um dos herbicidas mais usados para controle de plantas daninhas é o diuron, que é uma molécula não ionizável e, portanto tem nas interações hidrofóbicas o principal mecanismo de sorção. O 2,4-D também é um herbicida muito usado no Brasil, sendo um ácido fraco que sofre deprotonação nos valores de $\mathrm{pH}$ comumente encontrados nos solos agricultáveis e fica na forma aniônica. 
Portanto, as interações eletrostáticas também atuam como mecanismo de sua sorção.

Ao estudarmos a sorção de herbicidas, o tempo de residência e o grau de umidade do solo são fatores de grande importância. Para ocorrer à sorção do herbicida às partículas do solo é necessário um teor de água suficiente para a movimentação da molécula e tempo suficiente para que ocorra interação entre os colóides e o pesticida. A escolha dos Latossolos foi determinada com base em sua ampla extensão territorial brasileira.

Os objetivos da pesquisa foram avaliar a influência do teor de água do solo na mineralização e na sorção dos herbicidas 2,4-D e diuron, em quatro latossolos com diferentes quantidades de M.O.S., avaliar a influência do diferentes tamanhos de agregados (> 150, 54-150, 21-53, 2-20 e $<2 \mu \mathrm{m}$ ) na sorção dos herbicidas e determinar o grau de humificação da amostra de solo e dos agregados para explicar possíveis diferenças na sorção.

As hipóteses são que os agregados organominerais menores que $53 \mu \mathrm{m}$ serão responsáveis pela maior sorção dos herbicidas, e o maior grau de umidade do solo aumentará a mineralização e a sorção dos herbicidas. 


\section{REVISÃO DE LITERATURA}

\subsection{Herbicidas}

\subsubsection{Diuron}

É um herbicida não ionizável (Figura 1), com baixa solubilidade em água (42 $\mathrm{mg} \mathrm{L}^{-1}$ a $25^{\circ} \mathrm{C}$ ) e aplicado em pré-emergência para controle de plantas daninhas associadas à cultura da cana-de-açúcar, dentre outras (Musumeci et al., 1995). Pertence ao grupo das feniluréias, sendo um dos mais usados no Brasil (Esposito et al., 1998). O diuron inibe o transporte de elétrons no fotossistema II. Apresenta alta estabilidade em condições laboratoriais (Khadrani et al., 1999) e é relativamente persistente em solos (meia-vida de 90 a 180 dias) (Cullington \& Walker, 1999). Em alguns casos pode apresentar persistência superior a um ano (Sheets, 1964). A adição de carbono orgânico no solo promove o aumento da sorção do diuron, o que comprova sua afinidade à fração orgânica, que foi verificada por seu alto coeficiente de sorção de Freundlich $\left(K_{f}=24,4\right)$ em um Typic Haplaquolls, com 33,4 $\mathrm{g} \mathrm{kg}^{-1}$ de C.O. (Nkedi-Kizza et al., 1983) e $\left(\mathrm{K}_{\mathrm{f}}=\right.$ 23,15) em um Gleissolo Húmico, com 52,7 $\mathrm{g} \mathrm{kg}^{-1}$ de matéria orgânica, enquanto num Podzólico Vermelho-Amarelo, com $6,7 \mathrm{~g} \mathrm{~kg}^{-1}$ de matéria orgânica, sua sorção foi menor $\left(K_{\mathrm{f}}=1,94\right)$ (Luchini, 1987). 


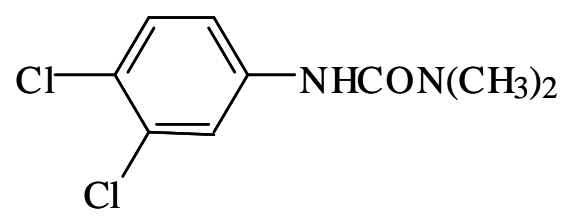

Figura 1 - Estrutura do diuron [3-(3,4-diclorofenil)-1,1-dimetiluréia]

\subsubsection{2,4-D}

Tem ação hormonal com inibição da síntese de RNA e proteína. O herbicida 2,4-D é uma molécula orgânica ionizável, ácido fraco (Figura 2), com potencial da sua constante de dissociação $\left(\mathrm{pK}_{\mathrm{a}}\right)$ do seu grupamento carboxílico $(\mathrm{COOH})$ igual a 2,8 (Johnson et al., 1995), ou seja nos valores de $\mathrm{pH}(5,5$ a 7,0) comumente encontrados nos solos agricultáveis sofre deprotonação, apresentando-se na forma aniônica, sendo repelido pelas cargas negativas do solo, como o que ocorre para outros pesticidas ionizáveis (Regitano et al., 1997; Rocha, 1999). Em solos com valores de pH 7,0 o 2,4-D apresentou baixa sorção (coeficiente de partição, $K_{d}$, de 0,06 a $0,19 \mathrm{mg} \mathrm{L}^{-1}$ ) (Johnson et al., 1995). Portanto, a sorção do 2,4-D é maior em solos com menor $\mathrm{pH}$ e maior conteúdo de matéria orgânica (Belmouden et al., 2000; Johnson et al., 1995). A alta solubilidade em água $\left(890 \mathrm{mg} \mathrm{\textrm {L } ^ { - 1 }}\right.$, a $\left.25^{\circ} \mathrm{C}\right)$ deste pesticida também favorece sua menor sorção. Na presença da luz o 2,4-D é degradado rapidamente, $12 \mathrm{~h}$ (Johnson et al., 1995), e o aumento da temperatura aumenta a degradação (Veeh et al., 1996). Deste modo, sua incubação deverá ser realizada com temperatura controlada e na ausência da luz. Nesta condição $50 \%$ da quantidade aplicada foi decomposta após 21 dias (Johnson et al., 1995). 


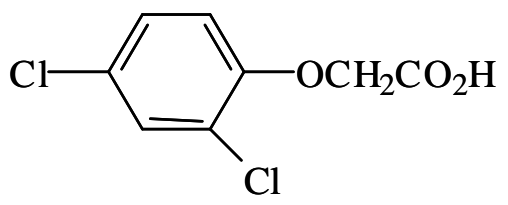

Figura 2 - Estrutura do 2,4-D [ácido 2,4-diclorofenoxiacético]

A presença da matéria orgânica aumentou a sorção de 2,4-D em um Latossolo Vermelho-Amarelo (Prado et al., 2001). Johnson et al. (1995) verificaram que a sorção deste herbicida foi diretamente proporcional ao teor de matéria orgânica e inversamente proporcional ao $\mathrm{pH}$ e ao teor de argila, mas os fatores dominantes na sorção foram os dois primeiros, como indicado pela seguinte equação ajustada: $\mathrm{K}_{\mathrm{d}}=1,493-0,197 \mathrm{pH}+0,163 \%$ M.O.S. $-0,00283 \%$ de $\operatorname{argila}\left(\mathrm{R}^{2}=0,93\right)$.

\subsection{Fracionamento físico e carbono orgânico}

Nos últimos anos, alguns métodos não destrutivos estão sendo usados a fim de fracionar a matéria orgânica do solo (M.O.S.). para o estudo de sua dinâmica no solo. $\mathrm{O}$ fracionamento físico causa menor modificação dos constituintes orgânicos que o fracionamento químico (Barriuso \& Koskinen, 1996). O método físico separa as frações orgânicas com diferentes propriedades químicas de acordo com sua associação com componentes minerais (Andreux et al., 1991; Turchenek \& Oades, 1979) e, a M.O.S. menos humificada (fração grosseira) da mais humificada (geralmente $<50 \mu \mathrm{m}$ ) (Barriuso \& Koskinen, 1996).

A dispersão do solo para o seu fracionamento em diferentes tamanhos físicos dos agregados baseia-se no mesmo princípio, o da dispersão em água, porém a relação solo:água varia entre os diferentes trabalhos, desde 1:3 (Tarchitzky et al., 2000) até 1:8 (Christensen, 1992). Para melhor dispersão a 
agitação e o banho de ultrassom são usadas em conjunto (Balesdent et al., 1987; Ladd et al., 1977). As frações maiores que $53 \mu \mathrm{m}$ são separadas por peneiras, já as menores que $53 \mu \mathrm{m}$ são separadas por sedimentação, que neste caso é usada a lei de Stokes para determinar o tempo de queda da partícula, que não é aplicada para aquelas maiores que $63 \mu \mathrm{m}$. É importante observar a relação entre o diâmetro das partículas e do recipiente usado para a sedimentação a qual deve ser menor que 1:100, além da temperatura da água que é preferível que seja mantida constante (Christensen, 1992). Durante a dispersão do solo, se ocorrer completa ruptura dos agregados, provavelmente os maiores compostos orgânicos remanescentes de plantas e animais também serão destruídos. Isto poderá alterar a composição da matéria orgânica nas frações físicas (Schulten \& Leinweber, 2000).

A M.O.S. possui a capacidade de alterar as propriedades físicas e químicas do solo, além de servir como fonte de carbono e nutrientes para microrganismos (Catroux \& Schnitzer, 1987). Além disso, a M.O.S. é o principal componente do solo responsável pela sorção de pesticidas por meio de interações hidrofóbicas (Green \& Karickhoff, 1990) e/ou por mecanismos de partição (Koskinen \& Harper, 1990).

A formação de frações estáveis são resultados da ação de diferentes constituintes. Nas frações menores que $0,2 \mu \mathrm{m}$ polímeros orgânicos e óxidos estão sorvidos às superfícies de argila, nas de 0,2 a $2 \mu \mathrm{m}$ restos de fungos recobrem minerais de argila, nas de 2 a $20 \mu \mathrm{m}$ restos de plantas e fungos recobrem minerais de argila, nas de 20 a $200 \mu \mathrm{m}$ presença de raízes e hifas (estabilidade orgânica moderada) e nas de 200 a $2000 \mu \mathrm{m}$ as partículas de areia estão recobertas com óxidos e freqüentemente associadas com resíduos de plantas, que são mais influenciadas pelo manejo (Tisdall \& Oades, 1982). 
A M.O.S. pode também afetar a microestrutura e a estabilidade de agregados do solo (Ristori et al., 1992). Macroagregados são formados pela associação temporária de microagregados e de partículas minerais e orgânicas (Oades, 1984; Tisdall \& Oades, 1982). Os microagregados têm maior estabilidade em água que os macroagregados, devido à grande força de ligação entre seus constituintes minerais e orgânicos, o que é conferido, em parte, pela ligação catiônica e pelos polissacarídeos de origem vegetal e microbiana (Bartoli et al., 1988; Sparling \& Cheshire, 1985). Mesmo em pequena quantidade, a M.O.S. é muito efetiva na estabilização de agregados, verificada pela baixa quantidade de argila dispersa em água em cinco Vertissolos, conforme observado por Ristori et al. (1992).

O conteúdo de carbono orgânico (C.O.) varia entre as frações físicas do solo. Com a diminuição do tamanho da partícula, maior a quantidade de CO (Nkedi-Kizza et al., 1983). Mais de $90 \%$ do C.O. está presente nas frações menores que $50 \mu \mathrm{m}$, o que indica um alto grau de humificação (Tisdall \& Oades, 1982). De acordo com alguns autores, a fração silte é a que mais contribui com o C.O. (Balesdent \& Mariotti, 1987; Catroux \& Schnitzer, 1987; Monrozier et al., 1991; Ristori et al., 1992). A presença de maior quantidade de C.O. na fração silte (2 a $50 \mu \mathrm{m}$ ) é devida à matéria orgânica promover a formação de agregados estáveis em água nessa faixa de tamanho (Ristori et al., 1992). Entretanto, outros consideram que a maior quantidade está presente na fração argila (Barriuso \& Koskinen, 1996; Christensen \& Sorensen, 1985). Porém a força imposta durante a dispersão do solo também determina a distribuição da matéria orgânica entre os diferentes tamanhos das frações físicas (Christensen, 1992). O tipo de solo influencia a distribuição de carbono orgânico entre os diferentes tamanhos de agregados (Schulten \& Leinweber, 2000). 
A natureza dos diferentes tamanhos das frações orgânicas e minerais influencia as interações físico-químicas dos pesticidas com o solo (Karickhoff \& Brown, 1978; Nkedi-Kizza et al., 1983). Porém, existem poucos estudos a respeito das interações entre os pesticidas e as diferentes frações físicas da M.O.S.. Evidencias experimentais indicam que pesticidas são preferencialmente ligados a partícula organomineral com maior quantidade de matéria orgânica (Schulten \& Leinweber, 2000). A quantidade de um herbicida sorvida pelo solo é diferente para cada uma de suas frações físicas. Os valores dos coeficientes de sorção do diuron aumentaram à medida que diminuiu o tamanho das partículas de um Typic Haplaquolls, que foi proporcional ao maior conteúdo de carbono orgânico (Nkedi-Kizza et al., 1983). A maior concentração de resíduo ligado de isoproturon nas menores frações é, provavelmente devido a formação de metabólitos capazes de se ligarem a matéria orgânica humificada, que se localiza preferencialmente nas frações menores que $53 \mu \mathrm{m}$ (Benoit et al., 2000). Barriuso \& Koskinen (1996) verificaram que a quantidade de atrazina ligada ao solo diminuiu à medida que o tamanho de partícula também diminuiu. Este herbicida ficou mais retido nas frações maiores que $50 \mu \mathrm{m}$ (matéria orgânica não humificada) devido a grande capacidade de ligação (Barriuso et al., 1991). Este resultado foi considerado inesperado pelos autores. Foi especulado que poderia ter ocorrido bioacúmulo nos microrganismos do solo, especialmente nos actinomycetos e nos fungos (Tisdall \& Oades, 1982), localizados nas frações maiores que $50 \mu \mathrm{m}$.

\subsection{Caracterização da fração orgânica}

A M.O.S. apresentada diferente grau de humificação nos diferentes solos, o que influencia na capacidade de interação com compostos orgânicos e inorgânicos adicionados. A melhor maneira de identificar o grau de humificação é 
por meio da combinação do fracionamento físico e da análise espectroscópica (Bayer et al., 2000). A possibilidade de menor alteração dos compostos presentes na M.O.S. é a maior vantagem de utilizar o fracionamento físico seguido pela análise espectroscópica, em relação ao procedimento químico tradicional (MartinNeto et al., 1994). A ressonância nuclear magnética (RNM) tem sido extensivamente usada para determinar a quantidade de grupos aromáticos e alifáticos e, deste modo, o grau de humificação das substâncias húmicas. Geralmente, a maior aromaticidade indica um estádio mais avançado de humificação (Preston, 1996). Esta interpretação é devida à associação da alta recalcitrância com os grupamentos químicos aromáticos presentes na M.O.S. (Stout et al., 1985). Uma outra propriedade que relata o grau de humificação da M.O.S. é a concentração de radicais livres estáveis, medida pela ressonância paramagnética eletrônica (RPE) (Senesi, 1990). A maior concentração de semiquinona, obtida pela RPE, indica um mais avançado grau de humificação e tem alta correlação com a aromaticidade determinada pela RNM (Bayer et al., 2000).

Geralmente, compostos orgânicos associados com a fração silte são ma is estáveis, menos biodegradáveis e tem maior aromaticidade, enquanto que compostos orgânicos associados à argila são mais lábeis, tem mais constituintes alifáticos e incluem mais resíduos bioquímicos da biomassa microbiana (Catroux \& Schnitzer, 1987; Ristori et al., 1992). Substâncias húmicas mais alifáticas provavelmente contribuem para menor formação de radicais livres de semiquinona (Bayer et al., 2000).

O uso combinado do fracionamento físico e da análise espectroscópica, particularmente a RPE e RNM, depende do conteúdo mineral das amostras, principalmente o de $\mathrm{Fe}^{3+}$, o que pode ser um impedimento para muitos solos brasileiros. Neste caso, teria que ser efetuada a extração dos ácidos húmicos para aplicar a RPE, considerando que a concentração de radicais livres de semiquinona 
em amostras de ácido húmico tem alta correlação com a da fração organo-mineral (Bayer et al., 2000).

A fluorescência é uma importante técnica analítica em que moléculas são excitadas por absorção de uma radiação eletromagnética. Quando as espécies excitadas relaxam para o estado fundamental, liberam o seu excesso de energia na forma de fótons. Esta técnica apresenta potencial para avaliar a humificação e o tamanho molecular de substâncias húmicas (Kalbitz et al., 1999; Zsolnay et al., 1999). A simplicidade, sensibilidade e rapidez são vantagens com o uso desta técnica. A fluorescência não tem o mesmo impedimento analítico como o RPE e RNM em relação ao $\mathrm{Fe}^{3+}$, por isso pode ser usada para determinar o grau de humificação em Latossolos sem a necessidade da extração de ácidos húmicos. Porém, a maioria dos trabalhos existentes usam esta técnica em substâncias húmicas (Milori et al., 2002b).

\subsection{Incubação dos solos}

Ao entrar em contato com o solo o comportamento de um herbicida é definido pelas suas propriedades físico-químicas e pelos atributos do solo. A estrutura do herbicida pode ser alterada caso a molécula esteja disponível para que ocorra alguma reação com a fonte promotora da alteração. A disponibilidade da molécula orgânica na solução do solo e o aumento da população de microrganismos são fundamentais para que o herbicida seja decomposto, por isso o teor de água é fundamental. A umidade interfere nos processos biológicos e abióticos que determinam o destino do pesticida. A água garante um ambiente com uma fonte de carbono, um herbicida, e íons disponíveis para que os microrganismos possam utilizá-los como fonte de energia. Um dos fatores que pode reduzir a decomposição do pesticida é a sorção, que necessita da água e do tempo de residência do composto orgânico no solo (Gaillardon \& Dur, 1995). O 
maior conteúdo de água tende a favorecer a sorção de compostos polares, como o diuron, por facilitar a difusão dentro dos agregados do solo e promover o acesso a novos sítios hidrofílicos. Isto também ocorre com alguns compostos ionizáveis tais como fenpropimorph e prochloraz (Roy et al., 2000). Além disso, a alta umidade pode aumentar a velocidade de sorção (Gaillardon, 1996). Porém, se o solo estiver muito úmido pode ocorrer redução na disponibilidade de oxigênio essencial para a degradação (Helweg, 1987; Flint \& Witt, 1997). Geralmente a baixa umidade da amostra tende a reduzir a degradação, como foram observados para alguns pesticidas, tais como picloram (Meikle et al., 1973), trifluralin (Zimdahl \& Gwynn, 1977), chlorsulfuron (Thirunarayanan et al., 1985), clomazone (Mervosh et al., 1995) e imazaquin e imazethapyr (Flint \& Witt, 1997). O menor conteúdo de água no solo reduz a sorção, pois nestas condições há menor difusão da molécula. O baixo conteúdo de umidade modifica a estrutura das substâncias húmicas e origina superfícies hidrofóbicas, que favorece a sorção de fungicidas hidrofóbicos tais como flusilazole, propiconazole e epoxiconazole. Este efeito provavelmente diminui com o aumento no caráter hidrofóbico de pesticidas não iônicos. Muitos compostos hidrofílicos, como o diuron, são mais sorvidos em solos com maior conteúdo de umidade devido a sua alta afinidade por regiões hidrofílicas de húmus. O efeito da umidade é mais complexo quando os compostos são protonados no solo (Roy et al., 2000).

O tempo de residência do pesticida no solo influencia no equilíbrio da sorção, com o passar do tempo mais moléculas difundem dentro dos pequenos poros do solo e/ou dentro da matriz orgânica do solo (Brusseau et al., 1991). A facilidade com que o herbicida é liberado depende também do tempo de residência, assim quanto maior o tempo mais difícil à extração das moléculas sorvidas (Gaillardon, 1996). 


\subsection{Latossolos}

As altas temperaturas aliadas ao alto índice pluvial da região tropical propiciam o avançado estágio de intemperização do material de origem. Os Latossolos apresentam pequena quantidade de minerais primários ou secundários pouco resistentes ao intemperismo. Possuem baixa capacidade de troca catiônica, menor que 170 mmol $\mathrm{kg}^{-1}$ (Embrapa, 1999). Variam de solos com predomínio de caulinita até àqueles com altos teores de óxidos na fração argila.

De modo geral, são solos fortemente ácidos, com baixa saturação por bases, distróficos ou álicos. Ocorrem em amplas áreas de diferentes relevos (Embrapa, 1999). Dentre eles temos os ácricos, que se caracterizam por possuir capacidade de troca de cátions efetiva $\left(\mathrm{Ca}^{2+}, \mathrm{Mg}^{2+}, \mathrm{K}^{+}, \mathrm{Na}^{+}\right.$e $\left.\mathrm{Al}^{3+}\right)$ menor que 15 mmol $_{\mathrm{c}} \mathrm{kg}^{-1}$ de argila e $\mathrm{pH}$ medido em $\mathrm{KCl} 1,0 \mathrm{~mol} \mathrm{~L}^{-1}$ maior ou igual a 5,0 ou $\Delta \mathrm{pH}\left(\mathrm{pH}_{\mathrm{KCl}}-\mathrm{pH}_{\mathrm{H} 2 \mathrm{O}}\right)$ positivo ou nulo (Embrapa, 1999). Estes solos encontram-se na posição de máximo acúmulo de óxidos de ferro (hematita e goetita) e alumínio (gibbsita), devido ao intenso processo de dessilicatização (Uehara, 1988).

Nestes solos, com carga variável, o potencial elétrico superficial $\left(\Psi_{0}\right)$ é controlado por íons determinadores de potencial e pela atividade dessas espécies na solução de equilíbrio (Yu, 1997). Para colóides com interface reversível, o potencial na superfície, em determinado $\mathrm{pH}$, é independente da concentração do eletrólito (Alleoni, 1992). Devido ao fato de a matéria orgânica contribuir para o decréscimo no valor do ponto de carga zero dos solos, que tem o valor médio ao redor de 2,0 (Uehara, 1988), os horizontes superficiais dos solos ácricos tendem a exibir elevado potencial elétrico negativo, o que ocasiona acentuada dispersão de argila e promove menor floculação (Levy et al., 1993).

A região Norte do Estado de São Paulo comporta uma agricultura de alta tecnologia com o uso, em algumas áreas, de irrigação para a produção de soja e cana-de-açúcar. Nesta região, Oliveira e Prado (1987) discriminaram 170000 ha 
de solos ácricos. À medida que aumenta o número de levantamentos detalhados de solos, maior o número de áreas de solos ácricos são descritas. Conseqüentemente, maior a importância do estudo da dinâmica de compostos orgânicos e inorgânicos nestes solos. 


\section{MATERIAL E MÉTODOS}

\subsection{Solos}

Foram utilizadas amostras de quatro Latossolos com diferentes teores de matéria orgânica: o Latossolo Amarelo distrófico (LAd), coletado em Piracicaba (São Paulo), o Latossolo Amarelo ácrico (LAw) e o Latossolo Vermelho ácrico (LVw-1), localizados no município de Uberlândia (Minas Gerais), e o Latossolo Vermelho ácrico (LVw-2), localizado no município de Canoinhas (Santa Catarina). As amostras de solos foram coletadas na camada superficial ( 0 a 0,2 m). Foram escolhidos locais que nunca receberam aplicação de herbicidas, principalmente diuron e 2,4-D.

\subsection{Análises químicas, físicas e mineralógicas}

A metodologia utilizada encontra-se em Camargo et al. (1986).

\subsubsection{Análises químicas}

- Matéria orgânica: obtida após oxidação da matéria orgânica do solo com solução de dicromato de potássio em presença de ácido sulfúrico e titulação do excesso de dicromato com sulfato ferroso amoniacal;

- teores de óxidos $\left(\mathrm{SiO}_{2}, \mathrm{Fe}_{2} \mathrm{O}_{3}\right.$ e $\left.\mathrm{Al}_{2} \mathrm{O}_{3}\right)$ : obtidos após ataque com ácido sulfúrico; 
- ferro "livre": em meio tamponado com bicarbonato de sódio $\mathrm{pH}$ 7,3, o ferro é reduzido pelo ditionito de sódio e complexado pelo citrato de sódio, permanecendo em solução;

- ferro mal critalizado ("amorfo"): obtido por solubilização do ferro mal cristalizado em ácido oxálico e seu sal de amônio;

- $\mathrm{pH}$ em $\mathrm{H}_{2} \mathrm{O}$, em $\mathrm{KCl} 1 \mathrm{~mol} \mathrm{~L} \mathrm{~L}^{-1}$ e $\mathrm{pH}$ em $\mathrm{CaCl}_{2}$ 0,01 mol $\mathrm{L}^{-1}$ : foi utilizada a relação solo-solução 1:2,5;

- a determinação do PESN foi de acordo com o método simplificado, que consiste no contato do solo com diferentes concentrações de ácido e base. São empregadas duas concentrações de cloreto de potássio $\left(0,05 \mathrm{~mol} \mathrm{~L}^{-1}\right.$ e $0,002 \mathrm{~mol}$ $\left.\mathrm{L}^{-1}\right)$. Depois de adicionar a menor concentração do sal, o contato foi mantido por 24 h. Na sequiência, o valor de $\mathrm{pH}$ foi lido e mais sal foi adicionado para atingir a maior concentração, que permanecu por $12 \mathrm{~h}$ em contato. Em seguida, foi efetuada nova leitura de $\mathrm{pH}$. $\mathrm{O} \Delta \mathrm{pH}$ foi calculado, e então foi ajustada uma equação com os valores de $\Delta \mathrm{pH}$ e o $\mathrm{pH}$ da menor concentração do sal. O PESN foi o valor de $\mathrm{pH}$ quando o $\Delta \mathrm{pH}$ foi igual a zero.

- fósforo (P): foi determinado em extratos ácidos de cloreto de sódio, provenientes da extração de solos pela resina trocadora de íons;

- $\mathrm{Ca}^{2+}, \mathrm{Mg}^{2+}$ e $\mathrm{K}^{+}$: foram extraídos com solução normal de acetato de amônio a pH 7,0 e seus teores foram determinados no extrato;

- $\mathrm{Al}^{3+}$ : foi determinado por meio de uma solução do sal neutro $\mathrm{KCl} 1,0$ $\operatorname{mol~L}{ }^{-1}$

- H+Al: foi extraído com solução de acetato de cálcio a pH 7,0.

A partir das análises anteriores foram calculados:

- $\mathrm{SB}$ ( soma de bases trocáveis) $=\mathrm{Ca}^{2+}+\mathrm{Mg}^{2+}+\mathrm{K}^{+}$;

- CTCe (capacidade de troca catiônica efetiva) $=\mathrm{SB}+\mathrm{Al}^{3+}$;

- CTCt (capacidade de troca catiônica total) $=\mathrm{SB}+\mathrm{H}+\mathrm{Al}$; 
- V\% (saturação por bases $)=(\mathrm{SB} \div \mathrm{CTCt}) \times 100$;

- $\mathrm{m} \%$ (saturação por alumínio) $=\left(\mathrm{Al}^{3+} \div \mathrm{CTCe}\right) \times 100$;

- cálculo do índice $\mathrm{Ki}$ (índice de intemperização) $=\left(\mathrm{SiO}_{2} / \mathrm{Al}_{2} \mathrm{O}_{3}\right) \times 1,7$; e

- cálculo do $\Delta \mathrm{pH}=\mathrm{pH} \mathrm{KCl}-\mathrm{pH} \mathrm{H} \mathrm{H}_{2} \mathrm{O}$.

\subsubsection{Análises físicas}

- $\quad$ Determinação da argila dispersa em água (ADA);

- $\quad$ análise granulométrica: pelo método do densímetro e

- $\quad$ superfície específica: foi usado o método de Cihacek \& Bremner (1979), baseado na técnica de retenção de éter monoetílico do etilenoglicol (EMEG) proposto por Heilman et al. (1965), com substituição da secagem do solo em estufa $\left(110^{\circ} \mathrm{C}\right.$ por 24 horas) ao invés do uso de $\mathrm{P}_{2} \mathrm{O}_{5}$ (Ratner-Zohar et al., 1983).

\subsubsection{Análise mineralógica qualitativa}

As amostras de argila foram tratadas para eliminação da matéria orgânica e dos óxidos de ferro. Com auxílio da difração de raios $X$, foi feita a determinação qualitativa nas amostras saturadas com $\mathrm{Mg}^{2+}$, glicoladas, e nas saturadas com $\mathrm{K}^{+}$e submetidas às temperaturas de 25,350 e $550^{\circ} \mathrm{C}$.

\subsection{Fracionamento físico e determinação do carbono orgânico}

Foram colocados $40 \mathrm{~g}$ de solo com $160 \mathrm{~mL}$ de água destilada (1:4) em tubos de centrífuga com capacidade para $250 \mathrm{~mL}$, os mesmos que foram usados para as amostras de solos com a presença das moléculas dos herbicidas marcadas com carbono-14. Esta suspensão foi agitada por 16 horas em um agitador horizontal e após foi colocada em banho de ultrassom a $240 \mathrm{~W}$ por 15 minutos. 
Depois de dispersa, a suspensão passou por duas peneiras, uma com malha de 150 $\mu \mathrm{m}$ e outra de $53 \mu \mathrm{m}$ de diâmetro, e assim foram separadas os agregados >150 e os de 54-150 $\mu \mathrm{m}$. A suspensão com as frações que passaram pela peneira de 53 $\mu \mathrm{m}$ foram transferidas para provetas com capacidade de $1000 \mathrm{~mL}$, que foram colocadas em uma sala climatizada a temperatura $22 \pm 2{ }^{\circ} \mathrm{C}$. A suspensão foi agitada com um agitador confeccionado com teflon, e o tempo de sedimentação foi determinado por meio da equação derivada da lei de Stokes, considerando uma densidade média de partículas de $2,65 \mathrm{~g} \mathrm{~cm}^{-3}$. A suspensão com as frações menores que $2 \mu \mathrm{m}$ foram retiradas com o uso de um sifão de teflon.

Após cada retirada, o volume da proveta foi completado com água, e a suspensão novamente agitada para fazer a nova retirada, sendo que esta sequiência foi repetida até que o líquido estivesse claro na profundidade de coleta de $0,10 \mathrm{~m}$. O mesmo foi realizado para a separação dos agregados com diâmetro entre 2 e 20 $\mu \mathrm{m}$. As frações com diâmetro entre 21 e $53 \mu \mathrm{m}$ permaneceram na proveta após a coleta das frações menores que $2 \mu \mathrm{m}$ e entre 2 e $20 \mu \mathrm{m}$. Na suspensão com as partículas menores que $2 \mu \mathrm{m}$ foi necessário adicionar solução de $\mathrm{CaCh}_{2}$,01 mol $\mathrm{L}^{-1}$ para auxiliar a floculação, sendo a água descartada. No caso das demais frações menores que $53 \mu \mathrm{m}$, não foi necessário adicionar $\mathrm{CaCh}$. Após a retirada da água, as frações foram secas em estufa a $55 \pm 5^{\circ} \mathrm{C}$.

As amostras secas das frações e do solo não fracionado, após serem moídas e passarem por peneira de diâmetro de malha $150 \mu \mathrm{m}$, foram submetidas à combustão (equipamento LECO CR 412), para extrair o carbono orgânico. 


\subsection{Atividade microbiana}

A atividade microbiana nos solos foi determinada pelo método da radiorespirometria, com o uso de ${ }^{14} \mathrm{C}$-glicose. As amostras dos solos permaneceram úmidas por 11 dias a $75 \%$ da capacidade de campo, para que depois fosse aplicada a glicose. Um grama de solo úmido foi colocado em um frasco respirométrico (quatro repetições). $\mathrm{Na}$ amostra de solo foi aplicado 0,30 $\mathrm{mL}$ de ${ }^{14} \mathrm{C}$-glicose de concentração igual a $2,0 \mu \mathrm{mol} \mathrm{mL} \mathrm{m}^{-1}$ para ser decomposta pelos microrganismos presentes. O mesmo volume foi adicionado em um frasco de cintilação com $10 \mathrm{~mL}$ de solução cintiladora para determinar a quantidade de radiação liberada pelos átomos de carbono-14 presentes nas moléculas de glicose existentes nos $0,30 \mathrm{~mL}$, sendo considerada a "atividade padrão". Para tampar o frasco respirométrico havia uma rolha na qual estava conectado um frasco suspenso onde foi adicionado $0,25 \mathrm{~mL}$ de monoetanolamina e colocada uma fita de papel de filtro. Os frascos respirométricos foram mantidos por uma hora em uma sala escura e com temperatura constante.

Depois de uma hora, o frasco suspenso contendo $0,25 \mathrm{~mL}$ de monoetanolamina e a fita de papel de filtro foi colocado em um frasco de cintilação com $10 \mathrm{~mL}$ de solução cintiladora. A seguir, o frasco suspenso foi lavado por cinco vezes com a solução cintiladora. Então, a radioatividade emitida foi lida, sendo denominada de "atividade microbiana" da amostra. A quantidade de glicose consumida (X) em $\mu \mathrm{mol}$ de glicose por grama por hora, foi determinada pela equação: $\mathrm{X}=\left(\mathrm{A} \div \mathrm{A}_{0}\right) \times(\mathrm{C} \div \mathrm{M}) \times(\mathrm{V} \div \mathrm{T})$, sendo $\mathrm{A}=$ "atividade microbiana" da amostra; $\mathrm{A}_{0}=$ "atividade padrão"; $\mathrm{C}=$ concentração da solução de glicose; $\mathrm{M}$ = massa de solo $(\mathrm{g}) ; \mathrm{V}$ = volume da solução de glicose usada $(\mathrm{mL})$ e T = tempo de incubação com a glicose (h). 


\subsection{Incubação dos solos com os herbicidas}

\subsubsection{LAd a $75 \%$ da capacidade de campo}

Foi realizado um teste de incubação de 2,4-D e diuron no Latossolo Amarelo distrófico (LAd) a $75 \%$ da capacidade de campo. A intenção era definir o tempo de incubação, a extração dos herbicidas e verificar as dificuldades durante o fracionamento físico nos diferentes tamanhos de agregados organominerais de um solo com a presença de moléculas radiomarcadas. Foram colocados $50 \mathrm{~g}$ do solo em frascos de Bartha, nos quais foi adicionada água suficiente para atingir $75 \%$ da capacidade de campo. O diuron com pureza de 96 $\%$ foi aplicado na dose de 3,2 kg i.a. ha ${ }^{-1}$ e o 2,4-D (ácido) com pureza de $99 \%$ na dose de $2,7 \mathrm{~kg}$ i.a. ha ${ }^{-1}$. Foram usadas as doses máximas dos herbicidas, conforme indicada para a cultura da cana-de-açúcar (Rodrigues \& Almeida, 1995). Juntamente com o produto não radiomarcado foram aplicadas moléculas radiomarcadas de diuron, com atividade específica de 2,43 $\mathrm{MBq} \mathrm{mg}^{-1}$, e de 2,4-D, com atividade específica de $2,51 \mathrm{MBq} \mathrm{mg}^{-1}$, ambos com radioatividade emitida de 41,7 kBq por frasco de Bartha.

Os herbicidas foram incubados por 15 dias em uma sala climatizada e semi-escura. Os frascos foram protegidos da exposição de luz. A mineralização dos herbicidas foi monitorada 24 horas após a aplicação e depois a cada dois dias até completar 15 dias, por meio da captura do ${ }^{14} \mathrm{C}-\mathrm{CO}_{2}$ em hidróxido de sódio. A leitura da radioatividade emitida foi feita a partir de duas alíquotas de 1,0 mL, retiradas dos $10 \mathrm{~mL}$ de $\mathrm{NaOH} 0,2 \mathrm{~mol} \mathrm{~L}^{-1}$ colocados no frasco de Bartha, que foram adicionadas em $10 \mathrm{~mL}$ de solução cintiladora.

Após a incubação, os $50 \mathrm{~g}$ de solo foram colocados em tubos de centrífuga com $150 \mathrm{~mL}$ de $\mathrm{CaCh}_{2} 0,01 \mathrm{~mol} \mathrm{~L}^{-1}$, sendo realizadas dez etapas de extração. Os tubos foram agitados por duas horas a 160 agitações $\min ^{-1}$. Após este 
período, a suspensão foi centrifugada a $10000 \mathrm{rpm}$ por 20 minutos, sendo retirado $1 \mathrm{~mL}$ do sobrenadante e adicionandos $10 \mathrm{~mL}$ de solução cintiladora para determinar a radioatividade emitida. Este processo foi repetido por três vezes com agitação dos tubos por duas horas e sete vezes com agitação dos tubos por 40 minutos. Após as dez extrações, a leitura da radioatividade emitida ficou constante. Depois desta etapa, as amostras foram secas e oxidadas para determinar o que ficou sorvido no solo. Do solo restante, $40 \mathrm{~g}$ foram usados para o fracionamento físico, realizado conforme detalhado no item 3.3 , sendo que 1 $\mathrm{mL}$ foi retirado para monitorar a radioatividade emitida por moléculas marcadas com C-14 que foram "remobilizadas".

\subsubsection{Incubação por 21 dias}

As dez extrações aumentaram a dispersão dos agregados, e a sorção foi baixa. Deste modo, foi alterado o tempo de incubação e modificadas as etapas de extração, para aumentar a quantidade de herbicida sorvido. Em frascos de Bartha, foram colocados $50 \mathrm{~g}$ do Latossolo Amarelo distrófico (LAd) e do Latossolo Amarelo ácrico (LAw), nos quais foi adicionada água suficiente para atingir 25, 50 e $75 \%$ da capacidade de campo, sendo duas repetições de cada teor de água. O solo foi mantido úmido em uma sala semi-escura e climatizada por três dias antes do início da incubação com os pesticidas. O diuron e o 2,4-D não radiomarcados foram aplicados conforme consta no item 3.5.1. Juntamente com o produto não radiomarcado foram aplicadas moléculas radiomarcadas de diuron e de 2,4-D com radioatividade emitida de $33,3 \mathrm{kBq}$ por frasco de Bartha. Os herbicidas foram incubados por 21 dias em uma sala climatizada e semi-escura. A mineralização dos herbicidas foi monitorada 24 horas após a aplicação e depois a cada quatro dias, por meio da captura do ${ }^{14} \mathrm{C}_{-} \mathrm{CO}_{2}$ em hidróxido de sódio. A leitura da radioatividade emitida foi feita conforme o item 3.5.1. Ao verificar 
diferenças de mineralização entre as repetições no mesmo teor de água, foi realizada a oxidação para verificar quanto de produto ficou sorvido.

Após a incubação, as amostras de solo foram colocadas em tubos de centrífuga com $150 \mathrm{~mL}$ de $\mathrm{CaCl}_{2} \quad 0,01 \mathrm{~mol} \mathrm{~L}^{-1}$. Os tubos foram agitados por 40 minutos a 160 agitações $\min ^{-1}$. Após este período a suspensão foi centrifugada a $10000 \mathrm{rpm}$ por 20 minutos, sendo retirado $1 \mathrm{~mL}$ do sobrenadante e adicionados $10 \mathrm{~mL}$ de solução cintiladora para determinar a radioatividade emitida. Este processo foi repetido mais quatro vezes, mas com solvente orgânico como extrator, na relação solo:solvente de 1:2, sendo que para as amostras com diuron foi usado metanol puro, enquanto para as amostras com 2,4-D foi usada acetonitrila mais água destilada (4:1). Depois desta etapa, as amostras foram secas e oxidadas para determinar o que ficou sorvido no solo. $O$ balanço de radioatividade variou em mais de $20 \%$ entre algumas repetições, por isso não foi realizado o fracionamento físico e uma nova incubação foi iniciada.

\subsubsection{Incubação por 42 dias}

Devido a problemas com o balanço de massa das amostras incubadas com o 2,4-D, iniciou-se um novo experimento nos mesmos solos (LAd e LAw) com os dois herbicidas, porém com algumas alterações. Antes de aplicar o 2,4-D no solo, foi realizado um teste para verificar se as moléculas foram completamente solubilizadas. A acetonitrila não solubilizou completamente as moléculas radiomarcadas, e por isso a acetona foi o solvente utilizado, o que resultou na total solubilizacão do produto. Para que no solo houvesse moléculas dos herbicidas radiomarcados suficiente para ser detectado nos agregados organominerais a serem separados, o tempo de incubação foi ampliado para 42 dias e foram modificadas as etapas de extração. 
Em frascos de Bartha, foram colocados $50 \mathrm{~g}$ dos solos, nos quais foi adicionada água suficiente para atingir 25,50 e $75 \%$ da capacidade de campo, sendo duas repetições de cada teor de água. O solo foi mantido úmido em uma sala semi-escura e climatizada por uma semana antes do início da incubação com os pesticidas. O diuron e o 2,4-D não radiomarcados foram aplicados conforme consta no item 3.5.1. Juntamente com o produto não radiomarcado foram aplicadas moléculas radiomarcadas de diuron e de 2,4-D com radioatividade emitida de $34,7 \mathrm{kBq}$ por frasco de Bartha. Os herbicidas foram incubados em uma sala climatizada e semi-escura, e os frascos foram revestidos. A mineralização dos herbicidas foi monitorada a cada sete dias, por meio da captura do ${ }^{14} \mathrm{C}-\mathrm{CO}_{2}$ em hidróxido de sódio. A leitura da radioatividade emitida foi feita conforme o item 3.5.1.

Após a incubação, as amostras de solo foram colocadas em tubos de centrífuga com $150 \mathrm{~mL}$ de $\mathrm{CaCh}_{2} 0,01 \mathrm{~mol} \mathrm{~L}^{-1}$. Os tubos foram agitados por 40 minutos a 140 agitações $\min ^{-1}$. Após este período a suspensão foi centrifugada a $10000 \mathrm{rpm}$ por 20 minutos, sendo retirado $1 \mathrm{~mL}$ do sobrenadante e adicionandos $10 \mathrm{~mL}$ de solução cintiladora para determinar a radioatividade emitida. Este processo foi repetido mais duas vezes, mas foi utilizado solvente orgânico como extrator na relação solo:solvente de 1:2. Para as amostras com diuron foi usado metanol puro e para as amostras com 2,4-D foi usada acetonitrila mais água destilada (4:1). Depois desta etapa, as amostras foram concentradas em um rotoevaporador e alíquotas de $100 \mu \mathrm{l}$ foram aplicadas em placa de TLC para verificar a pureza do produto. As amostras secas foram oxidadas para determinar o que ficou sorvido no solo, e logo após foi realizado o fracionamento físico das frações organominerais com a presença dos herbicidas.

Estas mesmas etapas foram novamente repetidas para os quatros solos LAd, LAw, LVw-1 e LVw-2, porém as três extrações foram realizadas somente com $\mathrm{CaCh}_{2}$ 0,01 mol L $\mathrm{L}^{-1}$, para avaliar a importância da difusão na sorção dos 
herbicidas e ter uma condição de extração dos herbicidas mais próxima possível do que ocorre na solução do solo.

\subsubsection{Determinação do grau de humificação}

Nas amostras dos solos e dos agregados organominerais foi incidido um feixe de laser com comprimento de onda de $351 \mathrm{~nm}$, potência de 0,248 W. A fluorescência emitida foi captada por um fotomultiamplificador com tensão de $839 \mathrm{~V}$. A varredura usada foi de $340 \mathrm{~nm}$ até $650 \mathrm{~nm}$ (passo 1). Os comprimentos de onda acima de 351 são todos emitidos pela amostra e por isso depende de sua estrutura. Durante a leitura das diferentes intensidades é formado um espectro (Anexo), do qual é calculada a área para a determinação do grau de humificação. Como o teor de carbono é variável entre as amostras o valor da área é normalizado. Deste modo, o valor da área calculado por integração do espectro é dividido pelo teor de carbono da amostra (Milori et al., 2002a). Esta análise foi realizada na Embrapa Instrumentação Agropecuária localizada em São Carlos/SP. 


\section{RESULTADOS E DISCUSSÃO}

\subsection{Atributos dos solos}

A reação do solo, que pode ser estimada pela medida do $\mathrm{pH}$, afeta os microrganismos e culturas, além de influir na disponibilidade de quase todos os nutrientes (Raij, 1991) e no comportamento de herbicidas ionizáveis (Rocha et al., 2000).

Um solo possui acidez alta, $\mathrm{pH}$ em $\mathrm{CaCl}_{2}=4,4-5,0$, e três solos possuem acidez muito alta, até 4,3 (Raij et al., 1985) (Tabela 1). Valores de pH muito baixo podem provocar a solubilização de alumínio, ferro e manganês, metais que podem ocasionar graves sintomas de toxidez nas plantas se absorvidos em quantidades elevadas (Raij, 1991). Os riscos de contaminação por alumínio podem ser verificados pelos altos valores de saturação por alumínio, exceto do Latossolo Amarelo distrófico, e estes valores tem relação inversa com os valores de $\mathrm{pH}$.

Durante a formação dos Latossolos a perda de cátions básicos é muito significativa, o que pode levar ao aumento da acidez. Os solos podem ser naturalmente ácidos, ou pela pobreza do material de origem em cátions básicos, ou por condições de pedogênese ou de formação do solo que favoreçam a remoção de elementos químicos do solo (Raij, 1991). 
Tabela 1. Análise química dos Latossolos ${ }^{\S}$

\begin{tabular}{|c|c|c|c|c|c|c|c|c|c|c|c|c|c|c|c|c|c|}
\hline Solo & M.O. & ------- & $---\mathrm{pH}-$ & -------- & $\Delta \mathrm{pH}$ & $\overline{P E S N}$ & $\bar{P}$ & $\bar{K}$ & $\overline{\mathrm{Ca}}$ & $\overline{\mathrm{Mg}}$ & $\overline{\mathrm{Al}}$ & $\mathrm{H}+\mathrm{Al}$ & SB & CTCe & $\mathrm{CTCt}$ & $\mathrm{V}$ & $\mathrm{m}$ \\
\hline $0-0,2 \mathrm{~m}$ & $\mathrm{~g} \mathrm{~kg}^{-1}$ & $\mathrm{CaCl}_{2}$ & $\mathrm{H}_{2} \mathrm{O}$ & $\mathrm{KCl}$ & & & $\mathrm{mg} \mathrm{kg}^{-1}$ & & & 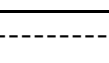 & 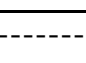 & $-\mathrm{mmol}_{\mathrm{c}} \mathrm{k}$ & $\mathrm{g}^{-1}$ & & & $\cdots$ & $\%$ \\
\hline LAd & $22^{\mathrm{d}^{*}}$ & $4,57^{\mathrm{a}}$ & $5,23^{\mathrm{a}}$ & $4,33^{\mathrm{a}}$ & $-0,90$ & $3,16^{\mathrm{b}}$ & $12,0^{\mathrm{a}}$ & $2,45^{\mathrm{a}}$ & $26,3^{a}$ & $11,3^{\mathrm{a}}$ & $16^{\mathrm{b}}$ & $68,7^{\mathrm{c}}$ & 40,05 & 56,05 & 108,75 & 37 & 29 \\
\hline LAw & $30^{\mathrm{c}}$ & $3,93^{b}$ & $4,50^{\mathrm{b}}$ & $4,07^{b}$ & $-0,43$ & $3,66^{\mathrm{a}}$ & $5,7^{\mathrm{c}}$ & $1,13^{\mathrm{bc}}$ & $2,0^{\mathrm{b}}$ & $1,0^{\mathrm{b}}$ & $14^{\mathrm{b}}$ & $91,3^{b}$ & 4,13 & 18,13 & 95,43 & 4 & 77 \\
\hline LVw- 1 & $37^{\mathrm{b}}$ & $4,03^{b}$ & $4,63^{b}$ & $4,10^{\mathrm{b}}$ & $-0,53$ & $3,67^{\mathrm{a}}$ & $8,0^{\mathrm{b}}$ & $1,30^{\mathrm{b}}$ & $1,0^{\mathrm{b}}$ & $1,0^{\mathrm{b}}$ & $16^{\mathrm{b}}$ & $99,7^{\mathrm{b}}$ & 3,30 & 19,30 & 103,00 & 3 & 83 \\
\hline LVw- 2 & $48^{\mathrm{a}}$ & $3,80^{\mathrm{c}}$ & $4,60^{b}$ & $3,83^{c}$ & $-0,77$ & $3,60^{\mathrm{a}}$ & $4,3^{\mathrm{c}}$ & $0,87^{\mathrm{c}}$ & $3,0^{\mathrm{b}}$ & $1,3^{\mathrm{b}}$ & $32^{\mathrm{a}}$ & $146,3^{\mathrm{a}}$ & 5,17 & 37,17 & 151,47 & 3 & 86 \\
\hline
\end{tabular}

* Médias com mesma letra não diferem a 5\% pelo teste de Tukey. ${ }^{\S}$ LAd = Latossolo Amarelo distrófico; LAw = Latossolo Amarelo ácrico; LVw - 1 = Latossolo Vermelho ácrico (Uberlândia); LVw-2 = Latossolo Vermelho ácrico (Canoinhas); $\mathrm{M} . \mathrm{O} .=$ matéria orgânica; $\mathrm{pH} \mathrm{H}_{2} \mathrm{O}$, pH $\mathrm{KCl} 1 \mathrm{~mol} \mathrm{~L}^{-1}$ e $\mathrm{pH} \mathrm{CaCl}{ }_{2}$ 0,01 mol L-1 = 1:2,5; PESN = ponto de efeito salino nulo; $\mathrm{SB}=$ soma de bases trocáveis; CTCe = Capacidade de troca catiônica efetiva; $\mathrm{CTCt}=\mathrm{Capacidade}$ de troca de catiônica total; $\mathrm{V} \%=$ saturação por bases e $\mathrm{m} \%=$ saturação por alumínio. 
A saturação por bases destes solos é baixa, $26-50 \%$, ou muito baixa, 0 - $25 \%$. Estes valores apresentam estreita correlação com os valores de pH (Tabela 1), condição esta já relatada para a maioria dos solos (Raij et al., 1985). O Latossolo Amarelo distrófico foi o que apresentou os maiores valores de cátions básicos (Tabela 1). A capacidade de troca de cátions destes solos é pouco ocupada pelo cálcio, magnésio e potássio, o que indica a condição de acidez alta ou muito alta (Raij, 1991). Os valores de fósforo foram baixos ou muito baixos (Tabela 1), resultado, provavelmente, da adsorção específica aos óxidos de ferro (Tisdale et al., 1993).

Os Latossolos foram selecionados com o intuito de terem diferentes quantidades de matéria orgânica (Tabela 1), pois este atributo é muito importante na sorção de herbicidas como o diuron (Luchini, 1987), pois os pesticidas são moléculas orgânicas. Predominam, portanto, as interações hidrofóbicas, que dependem do coeficiente de partição octanol/água $\left(\mathrm{K}_{\mathrm{ow}}\right)$ e da solubilidade em água do herbicida $\left(S_{\mathrm{w}}\right)$. Quanto maior o $\mathrm{K}_{\mathrm{ow}}$ e menor o $S_{\mathrm{w}}$, mais a molécula tende a permanecer na fase orgânica. Ocorre também sorção por forças de van der Waals e pontes de hidrogênio.

As quantidades de óxidos de ferro nas amostras dos solos foram médias $\left(80\right.$ a $180 \mathrm{~g} \mathrm{~kg}^{-1}$ ) e baixas $\left(<80 \mathrm{~g} \mathrm{~kg}^{-1}\right.$ ) (Tabela 2). Exceto no LVw-2, mais do que $50 \%$ do total de óxidos estão na forma "livre", que é a mais reativa, sendo a principal responsável pela geração de cargas positivas em solos com carga variável (Yu, 1997). Os óxidos de ferro são importantes nas interaçãos eletrostáticas com herbicida ácido fraco e troca de ligantes com moléculas que possuem grupo carboxílico (Evanko \& Dzombak, 1998). As formas "livres" do ferro predominam em relação às formas mal cristalizadas (Tabela 2). A relação $\mathrm{Fe}_{\mathrm{o}} / \mathrm{Fe}_{\mathrm{d}}$ foi de 0,08 para o LAd, de 0,04 para o LAw, de 0,04 para o LVw-1 e de 0,22 para o $\mathrm{LVw}-2$, o que indica alta cristalinidade, devido ao alto intemperismo a que estes solos foram submetidos (Sakurai et al., 1989). A partir dos valores do 
índice de intemperização (Ki) podemos inferir que estes solos apresentaram grande perda de silício.

Tabela 2. Quantidades de óxidos, índice $\mathrm{K}_{\mathrm{i}}$ e mineralogia dos Latossolos ${ }^{\S}$

\begin{tabular}{|c|c|c|c|c|c|c|c|}
\hline Solo & $\mathrm{SiO}_{2}$ & $\mathrm{Ab}_{2} \mathrm{O}_{3}$ & $\mathrm{Fe}_{2} \mathrm{O}_{3}$ & $\mathrm{Fe}_{\mathrm{d}}$ & $\mathrm{Fe}_{\mathrm{o}}$ & $\mathrm{K}_{\mathrm{i}}$ & Mineralogia \\
\hline $0-0,2 \mathrm{~m}$ & & & $\mathrm{~g} \mathrm{~kg}^{-1}$ & & - & & \\
\hline LAd & $118,0^{\mathrm{bc} *}$ & $121,9^{\mathrm{d}}$ & $57,5^{\mathrm{c}}$ & $34,2^{a}$ & $2,9^{\mathrm{b}}$ & 1,65 & $\mathrm{~K}, \mathrm{G}$ e VHE \\
\hline LAw & $166,7^{\mathrm{a}}$ & $333,3^{\mathrm{a}}$ & $62,8^{\mathrm{bc}}$ & $53,5^{\mathrm{b}}$ & $2,2^{\mathrm{b}}$ & 0,85 & $\mathrm{Ke} \mathrm{G}$ \\
\hline LVw-1 & $140,0^{\mathrm{ab}}$ & $305,2^{\mathrm{b}}$ & $104,2^{\mathrm{a}}$ & $87,9^{\mathrm{a}}$ & $3,9^{\mathrm{a}, \mathrm{b}}$ & 0,78 & $\mathrm{Ke} \mathrm{G}$ \\
\hline LVw-2 & $100,7^{\mathrm{c}}$ & $200,4^{\mathrm{c}}$ & $66,0^{\mathrm{b}}$ & $22,0^{\mathrm{d}}$ & $5,0^{\mathrm{a}}$ & 0,85 & $\mathrm{~K}, \mathrm{G}$ e VHE \\
\hline
\end{tabular}

* Médias com mesma letra não diferem a 5\% pelo teste de Tukey. ${ }^{\S}$ Óxidos obtidos após ataque com ácido sulfúrico. $\mathrm{Fe}_{\mathrm{d}}=$ ferro "livre", $\mathrm{Fe}_{\mathrm{o}}=$ ferro amorfo ou mal cristalizado. (LAd = Latossolo Amarelo distrófico; LAw = Latossolo Amarelo ácrico; LVw-1 = Latossolo Vermelho ácrico (Uberlândia); LVw-2 = Latossolo Vermelho ácrico (Canoinhas). $\mathrm{K}=$ caulinita, $\mathrm{G}=$ gibbsita e VHE = vermiculita hidroxi entre camadas.

Os solos estudados são argilosos e muito argilosos, e a quantidade de argila dispersa em água foi maior no Latossolo Amarelo distrófico (Tabela 3). As amostras do Latossolo Amarelo ácrico (LAw) e do Latossolo Vermelho ácrico (LVw-1), que estavam localizadas no ápice da chapada Sul-Americana, possuem diferentes quantidades de matéria orgânica, de óxidos de ferro e de alumínio, mas são mineralogicamente semelhantes (Tabelas 1 e 2 ). $O$ LAw se localizava em uma área de subsidência, onde o acúmulo de água era constante. Dessa forma, o Fe encontrou condições para redução e conseqüente solubilização, o que explica sua menor quantidade em relação ao LVw-1 (Tabela 2). As quantidades de óxidos de alumínio total foram altos nos LAw e LVw-1 e podem estar vinculadas à matriz muito argilosa composta por aluminossilicatos. 
Tabela 3. Análise física dos Latossolos ${ }^{\S}$

\begin{tabular}{lcccccc}
\hline Solo & $\begin{array}{c}\text { Areia } \\
\text { total }\end{array}$ & Silte & $\begin{array}{c}\text { Argila } \\
\text { total }\end{array}$ & ADA & $\begin{array}{c}\text { Flocu- } \\
\text { lação }\end{array}$ & SE \\
\hline $0-0,2 \mathrm{~m}$ & $-------------\mathrm{g} \mathrm{kg}^{-1}$ & & & $\%$ & $\mathrm{~m}^{2} \mathrm{~g}^{-1}$ \\
LAd & $490,0^{\mathrm{a}}$ & $100,0^{\mathrm{b}}$ & $410,0^{\mathrm{c}}$ & $240,0^{\mathrm{a}}$ & 41 & $18,0^{\mathrm{d}}$ \\
LAw & $186,7^{\mathrm{c}}$ & $43,3^{\mathrm{c}}$ & $770,0^{\mathrm{a}}$ & $93,3^{\mathrm{c}}$ & 88 & $25,9^{\mathrm{c}}$ \\
LVw-1 & $176,7^{\mathrm{c}}$ & $50,0^{\mathrm{c}}$ & $773,3^{\mathrm{a}}$ & $166,7^{\mathrm{b}}$ & 78 & $60,5^{\mathrm{b}}$ \\
LVw-2 & $296,7^{\mathrm{b}}$ & $160,0^{\mathrm{a}}$ & $543,3^{\mathrm{b}}$ & $80,0^{\mathrm{c}}$ & 85 & $89,5^{\mathrm{a}}$ \\
\hline
\end{tabular}

* Médias com mesma letra não diferem a $5 \%$ pelo teste de Tukey. ${ }^{\S}$ Frações: $2 \mathrm{~mm}>$ areia total $\geq 0,05>$ silte $\geq 0,002>$ argila total e argila dispersa em água (ADA). Floculação (\%) $=100 \times$ $($ argila total $-\mathrm{ADA}) /$ argila total. $\mathrm{SE}=$ superfície específica. LAd $=$ Latossolo Amarelo distrófico; LAw = Latossolo Amarelo ácrico; LVw-1 = Latossolo Vermelho ácrico (Uberlândia); LVw-2 = Latossolo Vermelho ácrico (Canoinhas).

\subsection{Degradação dos herbicidas}

A mineralização do 2,4-D foi maior quanto mais água havia na amostra de solo incubada (Figuras 3, 4 e 5). O mesmo não ocorreu para o diuron em todos os solos, pois na maioria deles a mineralização deste herbicida foi praticamente a mesma nas amostras com 25 e $50 \%$ e maior somente nas amostras incubadas com $75 \%$ da capacidade de campo. O mesmo foi verificado para o herbicida cloransulam-methyl num Typic Endoaquoll (Cupples et al., 2000), que foi mais mineralizado nas amostras com maior umidade. Estes resultados realçam a importância da água para manutenção de um ambiente com condições propícias à proliferação microbiana e para favorecer a difusão das moléculas dos herbicidas, que são fonte de carbono, para as regiões onde estão localizados os microrganismos e, deste modo, podem sofrer reações químicas que promovam sua quebra (Cupples et al., 2000). Porém, para que seja predominante a presença de microrganismos aeróbicos a umidade não pode ser alta, de modo a reduzir ou 
anular a disponibilidade de oxigênio essencial para a degradação (Flint \& Witt, 1997).
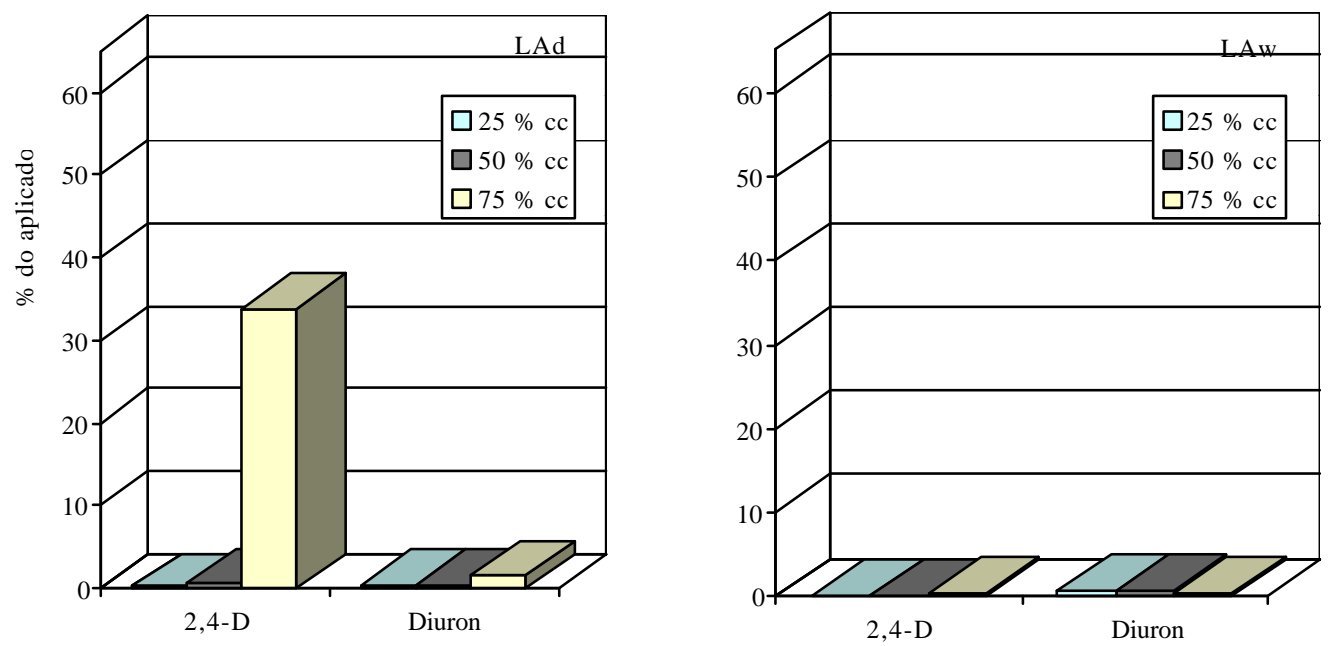

Figura 3 - Mineralização dos herbicidas após 21 dias de incubação do Latossolo Amarelo distrófico (LAd) e Latossolo Amarelo ácrico (LAw) com 25, 50 e $75 \%$ da capacidade de campo
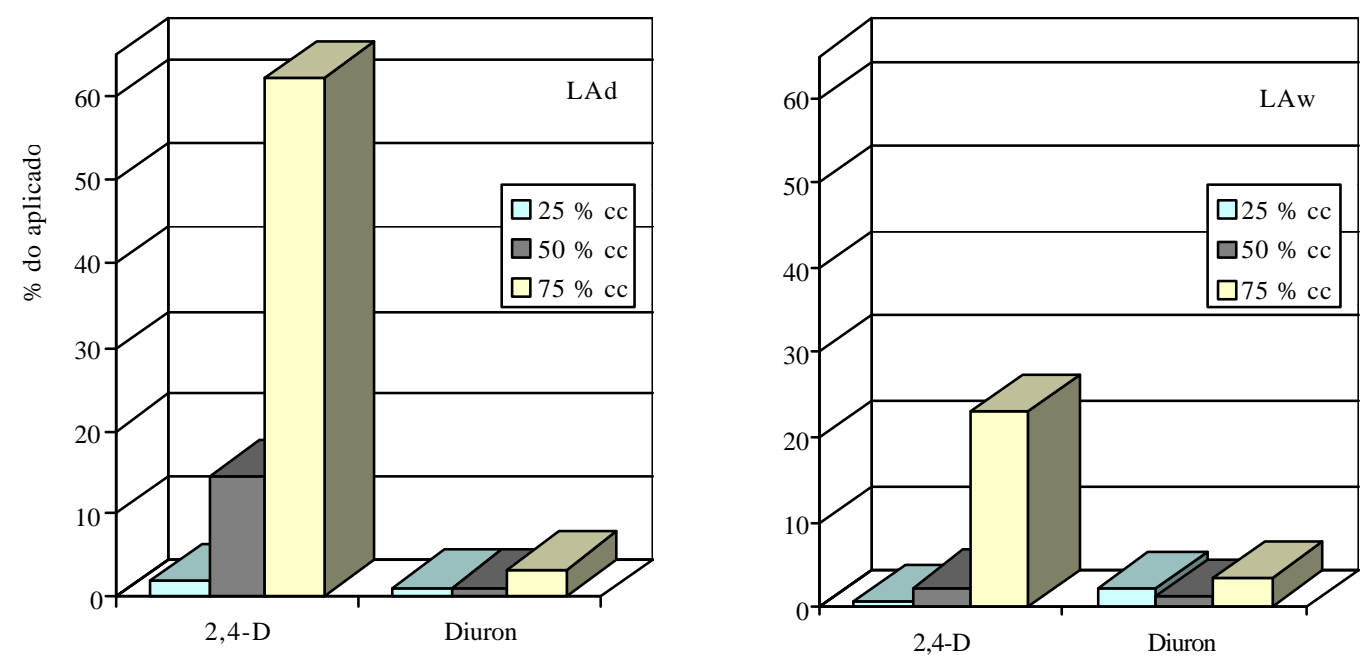

Figura 4 - Mineralização dos herbicidas após 42 dias de incubação do Latossolo Amarelo distrófico (LAd) e Latossolo Amarelo ácrico (LAw) com 25, 50 e $75 \%$ da capacidade de campo 

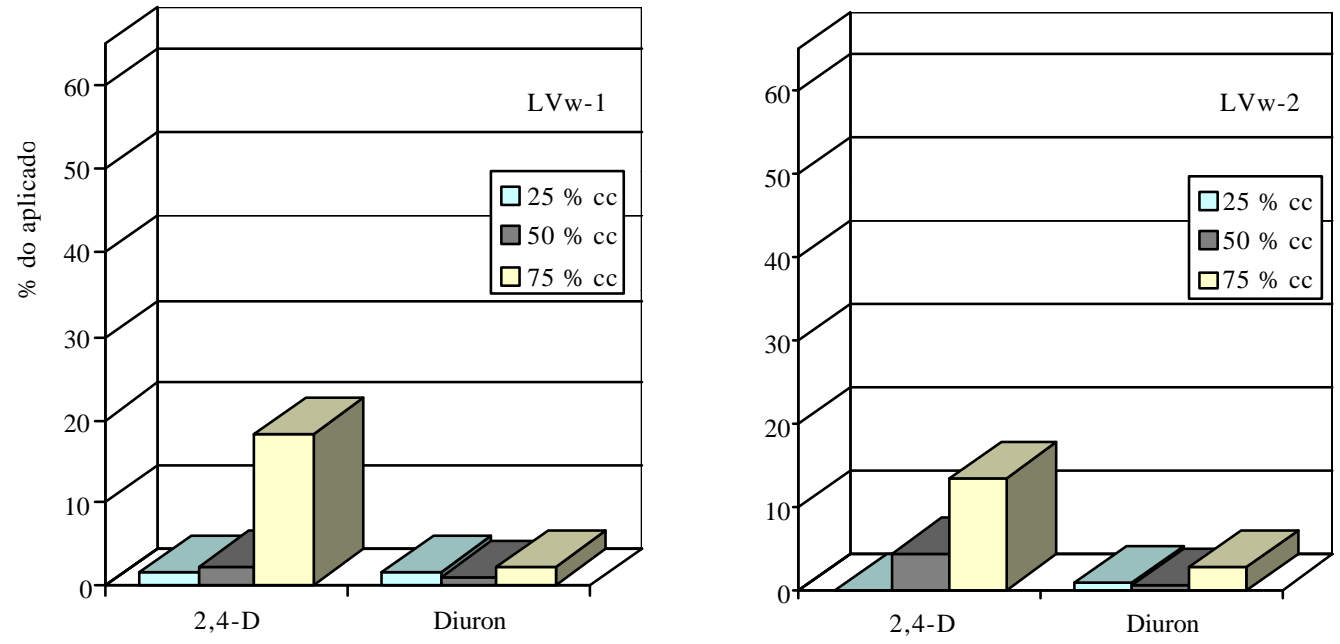

Figura 5 - Mineralização dos herbicidas após 42 dias de incubação dos solos Latossolo Vermelho ácrico (Uberlândia, LVw-1 e Canoinhas, LVw-2) com 25,50 e $75 \%$ da capacidade de campo

Por ser um ácido fraco e ser mais solúvel em água, o 2,4-D permaneceu em maior quantidade na solução do solo, o que determinou sua maior decomposição quando comparado com o diuron, que é mais persistente (Figuras 3, 4 e 5). A maior mineralização do 2,4-D nas amostras dos solos indica que este herbicida é mais facilmente utilizado pelos microrganismos como fonte de carbono do que o diuron. Isto realça a importância da forma estrutural da molécula orgânica na maior potencialidade em ser absorvida e degradada. Nas amostras que o 2,4-D e o diuron permaneceram mais tempo incubadas, maior foi a mineralização (Figuras 3 e 4). Para que o composto orgânico seja mineralizado, há necessidade que ele permaneça por um tempo suficiente no solo até que as suas moléculas possam se difundir e entrar em contato com os organismos que as irão decompor. Além disso, o tempo no qual os herbicidas permanecem na solução do solo é fundamental para que possam ocorrer as reações químicas. Kristensen et al. (2001) verificaram que o início da mineralização do 2,4-D ocorreu após um período denominado de aclimatização. 
O 2,4-D foi mais decomposto nas amostras do LAd do que nas dos outros solos, os quais seguiram a seguinte ordem decrescente de mineralização: LAd, LAw, LVw-1 e LVw-2. Como a atividade microbiana é praticamente a mesma entre os solos (Tabela 4), os atributos dos solos e sua interação com as propriedades físico-químicas das moléculas dos pesticidas foram determinantes nesta variação. A mineralização foi menor nos solos com as maiores quantidades de matéria orgânica e os menores valores de $\mathrm{pH}$ (Tabela 1). A quantidade de areia presente no solo pode ter sido importante na mineralização do 2,4-D. O LAd é o solo com maior quantidade de areia (Tabela 3), e foi nas amostras com $75 \%$ da capacidade de campo e após 42 dias de incubação que $62 \%$ do 2,4-D aplicado foi mineralizado (Figura 4). Kristensen et al. (2001) verificaram que $76 \%$ do 2,4-D aplicado foi mineralizado em uma camada arenosa, enquanto menos que $15 \%$ dos herbicidas mecoprop, isoproturon e terbuthylazine foram mineralizados. Os resultados evidenciam a característica da molécula do 2,4-D em ser mais facilmente utilizada pelos microrganismos como fonte de carbono, não só em comparação com o diuron.

Tabela 4. Atividade microbiana dos solos

\begin{tabular}{lc}
\hline Solos & Atividade microbiana \\
\hline & $\mu$ mol glicose $\mathrm{g}^{-1} \mathrm{~h}^{-1}$ \\
LAd & 0,017 \\
LAw & 0,013 \\
LVw-1 & 0,012 \\
LVw-2 & 0,005 \\
\hline
\end{tabular}

LAd = Latossolo Amarelo distrófico; LAw = Latossolo Amarelo ácrico; LVw-1 = Latossolo Vermelho ácrico (Uberlândia); LVw-2 = Latossolo Vermelho ácrico (Canoinhas). 


\subsection{Extração e sorção dos herbicidas}

As moléculas de 2,4-D e diuron foram menos extraídas com $\mathrm{CaCh}_{2}$ 0,01 mol L $\mathrm{L}^{-1}$ nas amostras incubadas com as maiores quantidades de água (Figuras $6 \mathrm{e}$ 7), o que confirma a importância da água na difusão dos herbicidas (Gaillardon, 1996; Roy et al., 2000). Para que o composto orgânico estabeleça o maior contato possível com a superfície sorvedora dos componentes do solo, é necessário que no meio tenha água suficiente para que as moléculas orgânicas sejam transportadas até os sítios de adsorção, e este comportamento depende também do tipo de herbicida (Gaillardon, 1996). O 2,4-D se comporta como um ânion e, por isso, é transportado como um íon até os sítios de carga positiva dos óxidos de ferro e alumínio e da matéria orgânica presentes no solo. O diuron, que é uma molécula polar, é difundido até os sítios hidrofílicos dos colóides. A maior difusão foi responsável pela maior sorção dos herbicidas às amostras dos solos com maior teor de água (Figuras 6 e 7), exceto no Latossolo Amarelo distrófico incubado com 2,4-D, no qual a grande quantidade de moléculas mineralizadas (Figura 4) mascarou de certa forma a sorção do pesticida. O maior teor de água favoreceu uma maior força de ligação dos herbicidas aos colóides, pois, as moléculas orgânicas foram menos extraídas nas amostras incubadas com maior grau de umidade.

$\mathrm{Na}$ maioria dos casos, o 2,4-D foi menos sorvido nas amostras do LAd do que nas amostras dos outros solos (Figuras 6 e 7). Os motivos desta diferença estão mais relacionados aos atributos do solo e às propriedades físico-químicas do herbicida. O LAd possui o maior valor de $\mathrm{pH}$, a menor quantidade de matéria orgânica, a menor quantidade de argila e a menor superfície específica (Tabela 3). No caso do 2,4-D, o valor de $\mathrm{pH}$ é de grande importância na sua sorção ao solo (Johnson et al., 1995). O 2,4-D é um composto orgânico ionizável que 

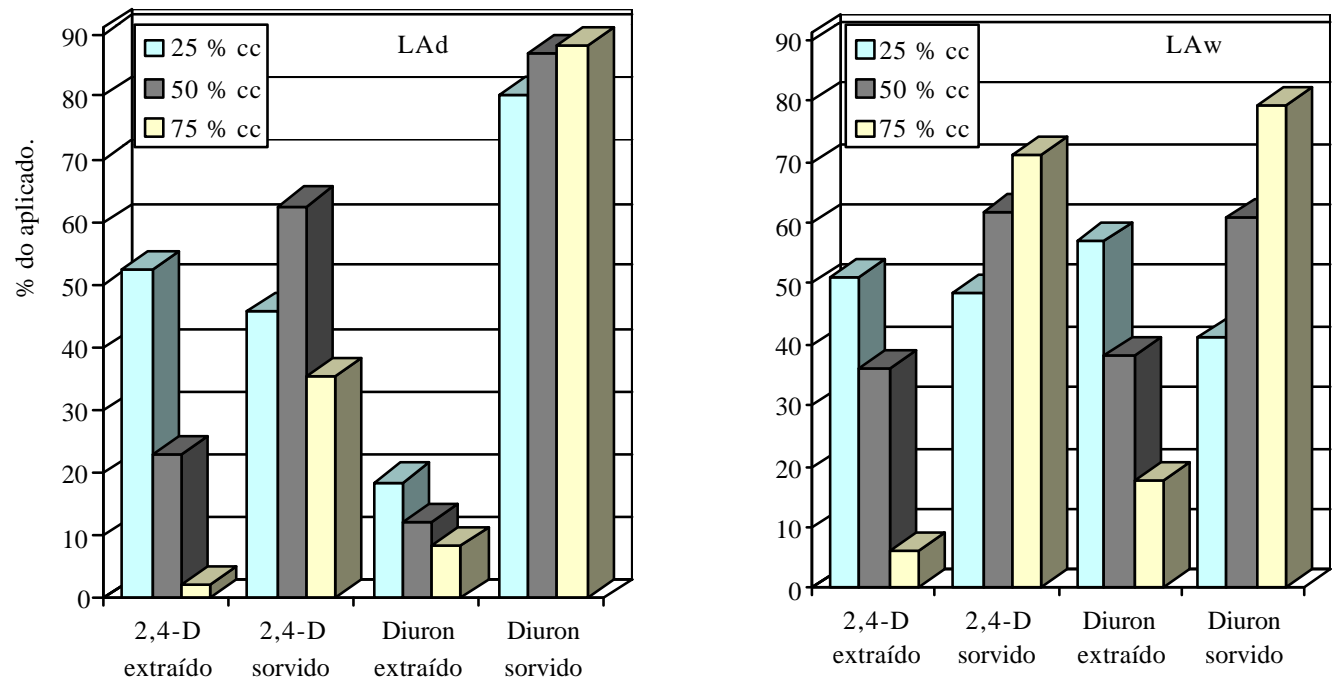

Figura 6 - Porcentagem extraída e sorvida dos herbicidas após 42 dias de incubação do Latossolo Amarelo distrófico (LAd) e Latossolo Amarelo ácrico (LAw) com 25, 50 e $75 \%$ da capacidade de campo
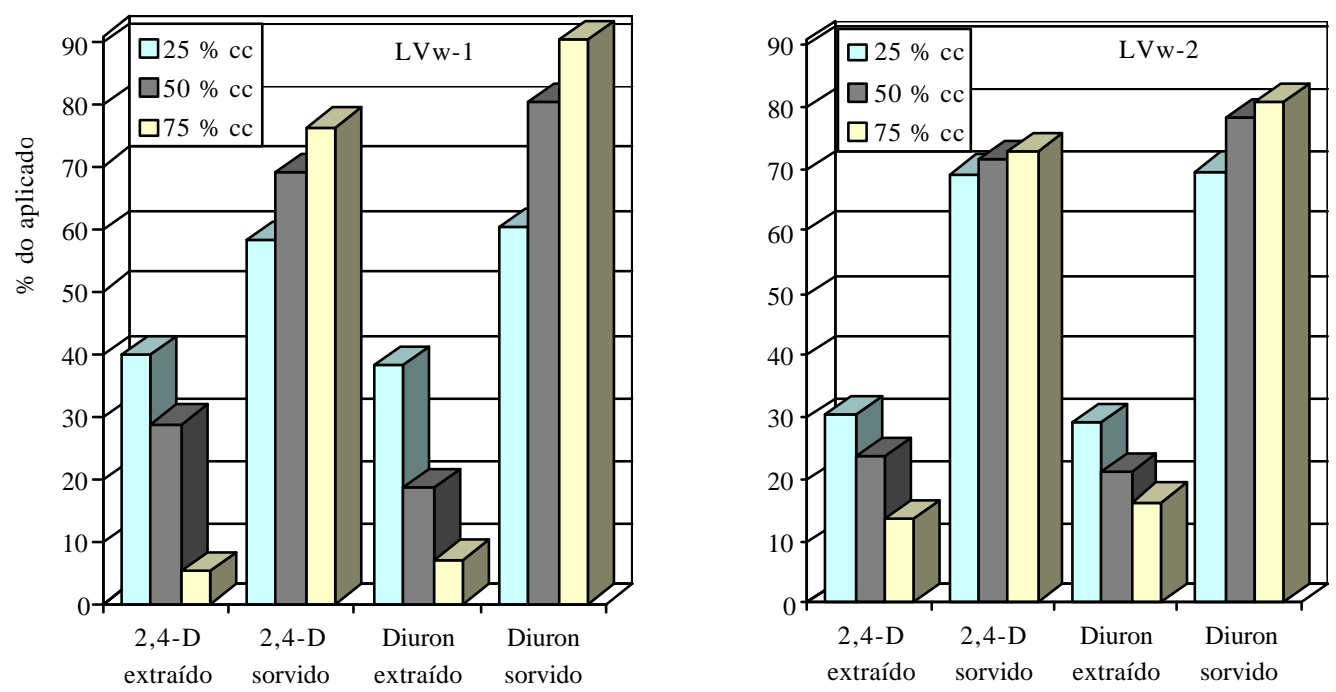

Figura 7 - Porcentagem extraída e sorvida dos herbicidas após 42 dias de incubação do Latossolo Vermelho ácrico (Uberlândia, LVw-1 e Canoinhas, LVw-2) com 25,50 e $75 \%$ da capacidade de campo 
apresenta característica de ácido fraco $\left(\mathrm{pK}_{\mathrm{a}}=2,8\right)$. Deste modo, no LAd, que apresenta maior valor de $\mathrm{pH}$, mais moléculas deste herbicida sofreram deprotonação do grupo carboxílico, o qual ficou carregado negativamente, sofrendo repulsão pelas cargas negativas permanentes e variáveis dos colóides deste solo. Estas condições ilustram a importância fundamental das interações eletrostáticas como mecanismo da sorção do 2,4-D (Grover \& Smith, 1974), como ocorre para outros herbicidas ionizáveis (Rocha et al., 2002).

A maior sorção do diuron nas amostras com maior umidade (Figuras 6 e 7) confirma a importância da água na difusão de moléculas polares (Roy et al., 2000). A polaridade das moléculas de diuron determina o seu transporte pela água presente no solo até às superfícies sorvedoras dos colóides do solo, principalmente aos sítios hidrofílicos dos húmus com os quais o diuron possui alta afinidade. Por este motivo, quanto mais água houver nos espaços porosos do solo, mais moléculas orgânicas serão transportadas (difundidas) para os microporos e para a matriz orgânica do solo (Brusseau et al., 1991).

\subsection{Fracionamento físico}

Os solos foram resistentes a dispersão em água (Tabela 5). A maior quantidade de agregados maiores que $53 \mu \mathrm{m}$ de um solo depende da quantidade de partículas de areia que ele possui e do grau de floculação das partículas de argila, que é o primeiro estágio na construção de um macroagregado estável em água (Tisdall \& Oades, 1982). Os agregados organominerais maiores que $53 \mu \mathrm{m}$ apresentaram revestimento de argila e carbono orgânico, que são fundamentais para definir o comportamento de pesticidas no solo. Isto foi observado para todos os solos, exceto o Latossolo Amarelo distrófico, que apresentou o predomínio de partículas de areia nas frações maiores que $53 \mu \mathrm{m}$. Por isso, mesmo tendo a menor quantidade de argila total (Tabela 3), o LAd apresentou a maior quantidade 
de agregados menores que $2 \mu \mathrm{m}$. Estes resultados estão em conformidade com a quantidade de argila dispersa em água (Tabela 3). A maior quantidade de agregados menores que $2 \mu \mathrm{m}$ do LAd pode ser devida a este solo possuir a menor quantidade de óxidos de ferro e alumínio (Tabela 2), além de menor quantidade de matéria orgânica (Tabela 1), que são responsáveis pela estabilização de agregados (Tarchitzky et al., 2000). A floculação e a dispersão do solo são muito influenciados pelas interações eletrostáticas, e a estabilização dos agregados maiores envolve agentes cimentantes ou ligantes os quais podem ser inorgânicos, orgânicos ou associações organominerais (Tisdall \& Oades, 1982). A maior diferença entre o pH e o PESN do LAd em relação aos outros solos (Tabela 1) confere a ele maior potencial elétrico superficial. Deste modo, este solo apresentou mais sítios com cargas negativas, o que ocasionou maior repulsão entre as partículas e entre os microagregados, por isso a dispersão foi maior neste solo (Tabela 3 e 5). Há evidências também que ânions orgânicos promovem a dispersão por bloquear sítios positivos na superfície dos colóides e por complexar cátions polivalentes em suspensão (Gillman, 1974).

Dos solos estudados, o LAd foi o único coletado de uma área usada para cultivo. As práticas culturais tradicionais, com remoção dos resíduos vegetais, são responsáveis pela redução no conteúdo de matéria orgânica do solo. Com o cultivo, os agregados e a matéria orgânica, antes inacessível aos microrganismos, são expostos e assim há estímulo à sua oxidação e conseqüente perda. Como a matéria orgânica também é responsável pela agregação das partículas do solo, sua redução proporciona a diminuição no número de agregados estáveis em água (Tisdall \& Oades, 1982).

Óxidos de ferro e alumínio cimentam partículas em agregados estáveis em água com diâmetro maior que $100 \mu \mathrm{m}$, especialmente em solos que contém mais que $10 \%$ de óxidos (Tisdall \& Oades, 1982). Os macroagregados (> 250 
$\mu \mathrm{m})$ são complexos argila-metal-matéria orgânica, nos quais as argilas são ligadas por metais polivalentes à matéria orgânica humificada. Ligações de óxidos de ferro e alumínio, argila-metal-argila, matéria orgânica-metal-matéria orgânica, ou pontes de hidrogênio também podem ocorrer (Edwards \& Bremner, 1967). As interações entre polímeros orgânicos e superfícies minerais são complexas. O mais importante mecanismo de interação envolve, provavelmente, ligações de cátions polivalentes entre a superfície de partículas de argila ou polímeros de hidróxidos e grupos ligantes de polímeros orgânicos, como grupos carboxílicos (Tisdall \& Oades, 1982).

Tabela 5. Quantidades dos diferentes agregados organominerais dos solos

\begin{tabular}{lccccc}
\hline \multirow{2}{*}{ Solos } & \multicolumn{5}{c}{ Agregados organominerais $(\mu \mathrm{m})$-------- } \\
\cline { 2 - 5 } & $\mathrm{A}>150$ & $53<\mathrm{A}<150$ & $20<\mathrm{A}<53$ & $2<\mathrm{A}<20$ & $\mathrm{~A}<2$ \\
\hline \multirow{2}{*}{ LAd } & 399,0 & 174,5 & 73,0 & 89,9 & 263,7 \\
LAw & 440,8 & 181,1 & 101,5 & 123,4 & 153,2 \\
LVw-1 & 413,2 & 167,7 & 87,8 & 160,5 & 170,8 \\
LVw-2 & 363,1 & 280,7 & 128,8 & 155,3 & 72,1 \\
\hline
\end{tabular}

LAd = Latossolo Amarelo distrófico; LAw = Latossolo Amarelo ácrico; LVw-1 = Latossolo Vermelho ácrico (Uberlândia); LVw-2 = Latossolo Vermelho ácrico (Canoinhas).

\subsubsection{Carbono orgânico nos agregados organominerais}

O grau de disagregação do solo alcançado durante a dispersão das amostras é decisivo para a distribuição da matéria orgânica entre os agregados de diferentes tamanhos (Christensen, 1992). A força usada para dispersar o solo define a maior ou menor quantidade de M.O.S. em determinado tamanho de agregado. O tipo de solo também influencia a distribuição da matéria orgânica entre os agregados. Em Mollisols, a concentração máxima de carbono foi 
observada na fração silte mais "fina" (2 - 5 $\mu \mathrm{m})$, enquanto em Alfisols a fração argila contribui com a maior concentração de carbono (Christensen, 1992). Por isso, há necessidade de padronizar a força de dispersão entre os tipos de solos. Após a dispersão do solo, a quantidade de carbono orgânico (C.O.) varia entre os agregados organominerais.

Solos com grande quantidade de M.O.S. na fração leve podem apresentar um maior conteúdo de M.O.S. nos agregados de tamanho "areia" (Angers \& Mehuys, 1990). A quantidade de C.O. foi maior nos agregados com diâmetro equivalente ao "silte" e à "argila" (agregados menores que $53 \mu \mathrm{m}$ ) (Tabela 6), como foi observado na maioria dos trabalhos existentes (Barriuso \& Koskinen, 1996; Christensen \& Sorensen, 1985; Monrozier et al., 1991; Ristori et al. 1992). Os macroagregados são formados pela ligação entre microagregados que é, na maioria dos casos, promovida por material orgânico mais alifático, ou seja, menos humificado. Durante a degradação da M.O.S. há quebra da ligação entre os microagregados e há aumento da quantidade estruturas orgânicas mais humificadas (anéis aromáticos), que revestem os microagregados e as partículas de tamanho argila. Por isso, neste solos o carbono orgânico presente nos agregados menores que $53 \mathrm{~mm}$ podem ter maior grau de humificação (Tisdall \& Oades, 1982), o que determina a maior estabilidade destes agregados.

Para comparar a concentração de M.O.S. nas frações silte e argila dos diferentes solos e caracterizar o acúmulo preferencial da matéria orgânica, a razão de enriquecimento de carbono foi calculada para cada fração (Christensen, 1992). Os agregados entre 2 e $20 \mu \mathrm{m}$ ("silte") foram os que tiveram maior acúmulo de carbono orgânico, exceto o LAw. Mesmo assim, foram os agregados "silte" de maior diâmetro (entre 20 e $53 \mu \mathrm{m}$ ) que tiveram maior acúmulo de carbono orgânico (Tabela 6). O maior acúmulo nos agregados "silte' e "argila" destes solos está em conformidade com Christensen (1992). Este autor relata que na 
fração silte de 2 a $5 \mu \mathrm{m}$ a quantidade de carbono variou de 1,3 a 4,0 vezes a quantidade presente no solo. Já na argila a quantidade pode ser de até 11,1 vezes a existente no solo.

Tabela 6. Quantidade e razão de enriquecimento de carbono

\begin{tabular}{|c|c|c|c|c|c|c|}
\hline \multirow[b]{2}{*}{ Solos } & \multicolumn{5}{|c|}{ 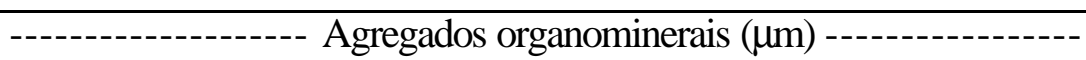 } & \multirow{2}{*}{$\begin{array}{l}\text { Solo } \\
\text { total }\end{array}$} \\
\hline & $A>150$ & $53<\mathrm{A}<150$ & $20<\mathrm{A}<53$ & $2<\mathrm{A}<20$ & $\mathrm{~A}<2$ & \\
\hline & \multirow{2}{*}{\multicolumn{5}{|c|}{ - }} & \\
\hline & & & & & & $\mathrm{g} \mathrm{kg}^{-1}$ solo \\
\hline LAd & 13,1 & 6,6 & 14,7 & 29,9 & 18,8 & 15,6 \\
\hline LAw & 20,4 & 19,7 & 36,1 & 23,8 & 20,8 & 21,2 \\
\hline LVw-1 & 30,2 & 22,6 & 29,8 & 55,7 & 26,8 & 28,8 \\
\hline \multirow[t]{2}{*}{$\mathrm{LVw}-2$} & 34,6 & 22,6 & 24,8 & 47,1 & 45,7 & 32,6 \\
\hline & \multicolumn{6}{|c|}{ 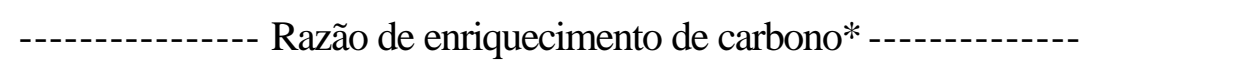 } \\
\hline LAd & 0,8 & 0,4 & 1,0 & 1,9 & 1,2 & \\
\hline LAw & 1,0 & 0,9 & 1,7 & 1,1 & 1,0 & \\
\hline LVw-1 & 1,1 & 0,8 & 1,0 & 1,9 & 0,9 & \\
\hline LVw-2 & 1,1 & 0,7 & 0,8 & 1,5 & 1,4 & \\
\hline
\end{tabular}

* Razão de enriquecimento de carbono $=\left(\mathrm{gC} \mathrm{kg}^{-1}\right.$ agregado $) /\left(\mathrm{gC} \mathrm{kg}^{-1}\right.$ solo $)$. LAd $=$ Latossolo Amarelo distrófico; LAw = Latossolo Amarelo ácrico; $\mathrm{LVW}_{\mathrm{w}} 1$ = Latossolo Vermelho ácrico (Uberlândia); LVw-2 = Latossolo Vermelho ácrico (Canoinhas).

\subsubsection{Sorção dos herbicidas nos agregados organominerais}

Os herbicidas são moléculas orgânicas, e tendem a serem sorvidos pelos agregados com os maiores conteúdos de matéria orgânica (Schulten \& Leinweber, 2000). No Latossolo Amarelo distrófico incubado por 15 dias, os herbicidas 2,4 $\mathrm{D}$ e diuron foram mais sorvidos nos agregados organominerais menores que 20 $\mu \mathrm{m}$, que são os com maior acúmulo de carbono (Tabela 6), o que está em conformidade com a maioria dos trabalhos científicos (Benoit et al., 2000; Nkedi- 
Kizza et al., 1983). Os agregados menores que $2 \mu \mathrm{m}$ sorveram 2,2 vezes mais 2,4 $\mathrm{D}$ do que a fração entre 2 e $20 \mu \mathrm{m}$. Já o diuron foi sorvido 8,1 vezes mais nos agregados de diâmetro entre 2 e $20 \mu \mathrm{m}$ que nos menores que $2 \mu \mathrm{m}$ (Figura 8). Isto evidencia que a dinâmica do composto orgânico depende de sua propriedade físico-química. A maior sorção do diuron aos agregados que possuem maior quantidade de carbono orgânico pode ser devido ao seu caráter polar e, por isso ser sorvido pelos sítios hidrofílicos. Mesmo tendo menos que $9 \%$ dos agregados entre 2 e $20 \mu \mathrm{m}$, eles são responsáveis pela maior sorção do diuron, o que demonstra a importância destes agregados na dinâmica deste herbicida. Considerando que com a erosão as partículas de menor diâmetro possam ser transportadas a maiores distâncias, no caso deste solo, a maior parte das moléculas dos herbicidas poderia ser deslocada sorvida às partículas (Schuz, 2001) em direção a locais nos quais sua presença não seria necessária.

Alguns experimentos foram realizados no intuito de mostrar a importância do escorrimento superficial, "runoff", no transporte de pesticidas no ambiente, e destacam-se os trabalhos de Konda \& Pasztor (2001), para o herbicida atrazina e os de Connolly et al. (2001) para o endosulfan.

No LAd incubado por 42 dias com diferentes teores de água e após três extrações, uma com $\mathrm{CaCh}_{2}$ 0,01 mol $\mathrm{L}^{-1}$ e duas com solvente, a sorção do 2,4-D foi maior nos agregados menores que $2 \mu \mathrm{m}$ (Figura 9), sendo o mesmo observado por Haberhauer et al. (2000). Esta fração é considerada por alguns pesquisadores como a mais importante na sorção de herbicidas (Barriuso \& Koskinen, 1996). Esta fração não possui a maior quantidade de carbono (Tabela 6), mas por ser da fração argila possui maior superfície de contato, o que foi determinante na sorção do 2,4-D. No caso do diuron, os agregados organominerais responsáveis pela maior sorção estavam entre 2 e $20 \mu \mathrm{m}$ (Figura 10), o que condiz com diferentes 


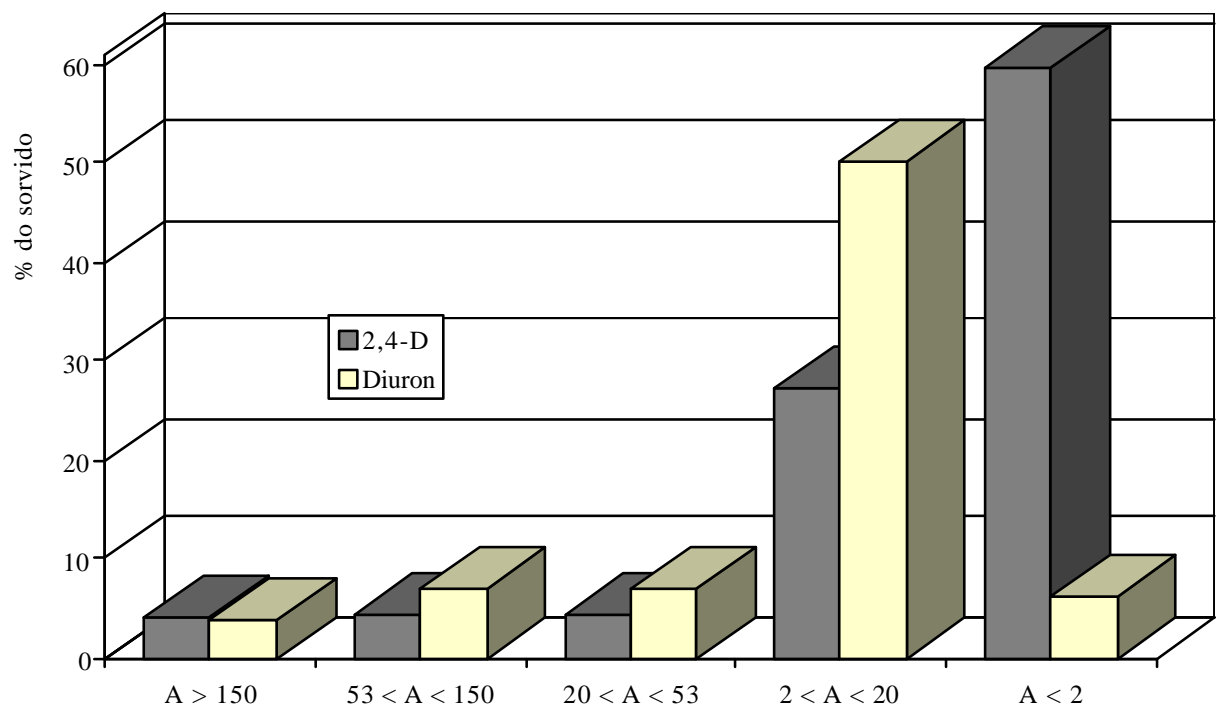

Figura 8 - Porcentagem sorvida dos herbicidas nos agregados $(\mathrm{A}, \mu \mathrm{m})$ do LAd incubado por 15 dias e após 10 extrações com $\mathrm{CaCh}_{2} 0,01 \mathrm{~mol} \mathrm{~L}^{-1}$

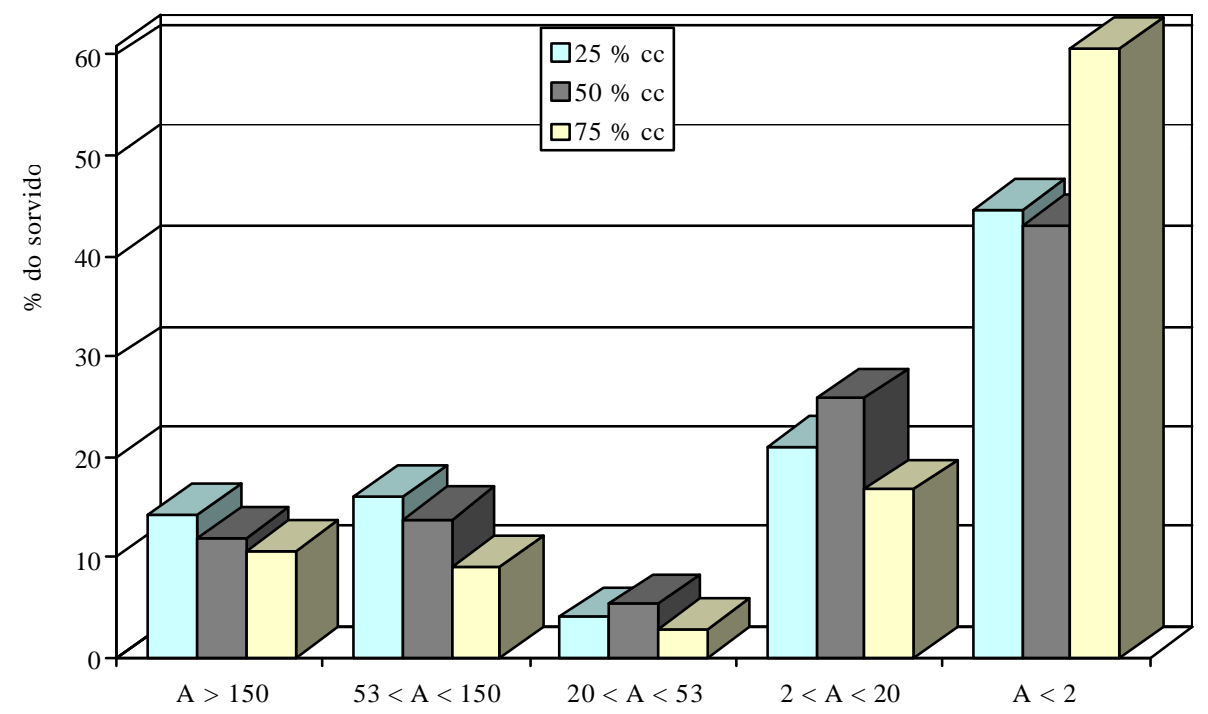

Figura 9 - Porcentagem sorvida do 2,4-D nos agregados (A, $\mu \mathrm{m})$ do LAd incubado por 42 dias e após uma extração com cloreto e duas com solvente 


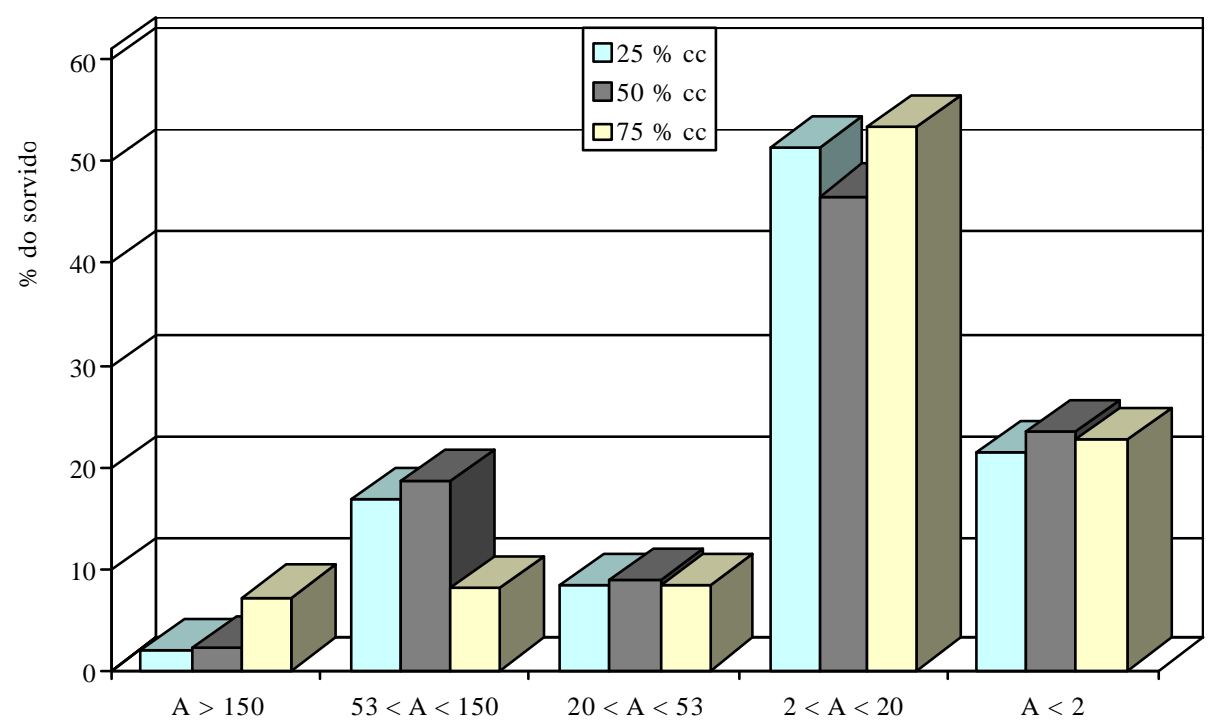

Figura 10 - Porcentagem sorvida do diuron nos agregados $(\mathrm{A}, \mu \mathrm{m})$ do LAd incubado por 42 dias e após uma extração com cloreto e duas com solvente

resultados que consideram a fração "silte" como a principal sorvedora de pesticidas. Estes agregados foram os que apresentaram a maior quantidade de carbono orgânico (Tabela 6), que é o atributo mais importante na sorção de herbicidas não ionizáveis, como o diuron. Na amostra do LAd incubada com 75 $\%$ da capacidade de campo, a quantidade de 2,4-D sorvida pelos agregados menores que $2 \mu \mathrm{m}$ foi maior do que nas amostras incubadas com 25 e $50 \%$ da capacidade de campo, o que confirma a importância da água na difusão das moléculas dos pesticidas nos agregados maiores. O mesmo foi verificado para os agregados obtidos após fracionamento físico das amostras de LAd nas quais os herbicidas 2,4-D e diuron foram extraídos três vezes com $\mathrm{CaCh}_{2} 0,01 \mathrm{~mol} \mathrm{~L}^{-1}$ (Figuras 11 e 12). Deste modo, mesmo ao alterar o extrator nas amostras do LAd antes do fracionamento, a distribuição dos herbicidas nos diferentes agregados organominerais deste solo não foi modificada. 


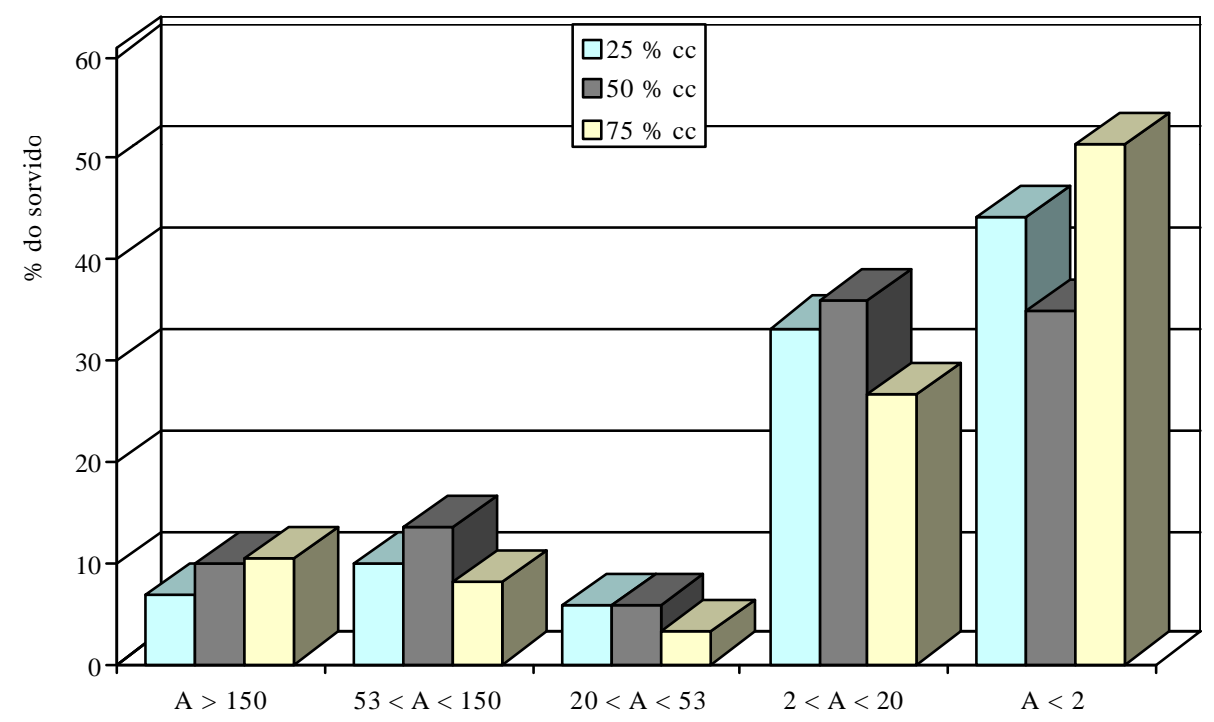

Figura 11 - Porcentagem sorvida do 2,4-D nos agregados $(\mathrm{A}, \mu \mathrm{m})$ do LAd incubado por 42 dias e após três extrações com $\mathrm{CaCb}$ 0,01 mol L $\mathrm{L}^{-1}$

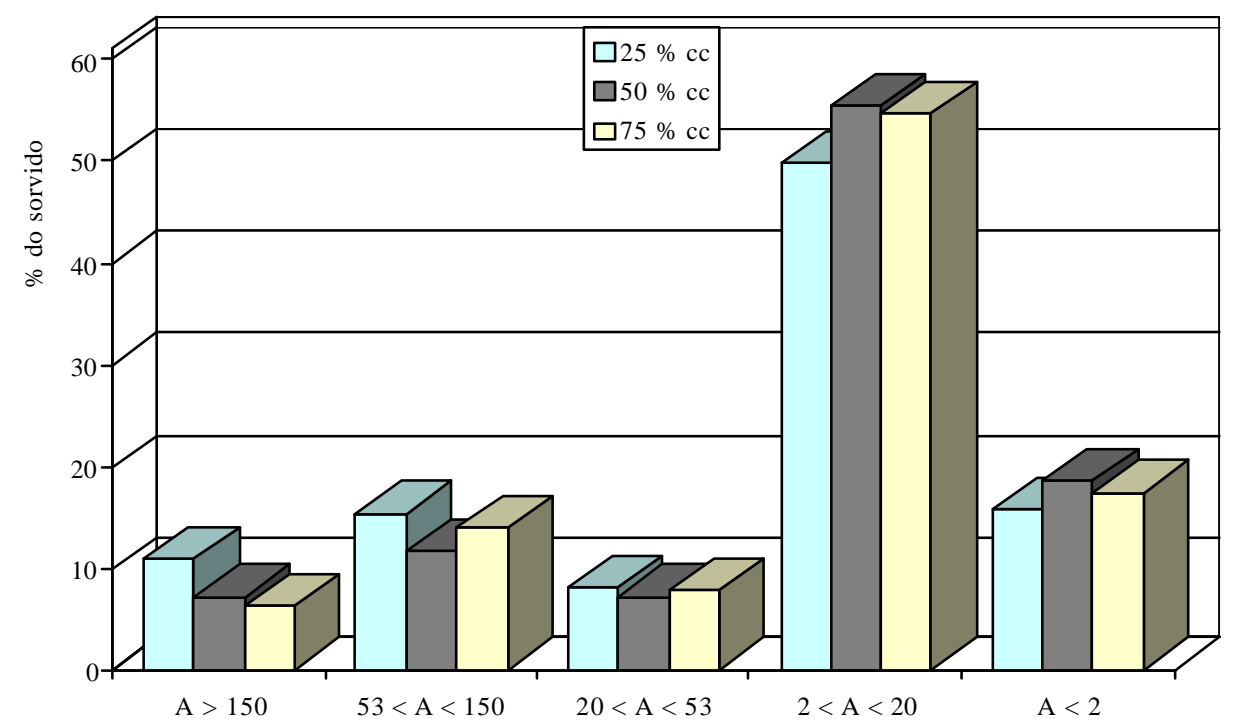

Figura 12 - Porcentagem sorvida do diuron nos agregados $(\mathrm{A}, \mu \mathrm{m})$ do LAd incubado por 42 dias e após três extrações com $\mathrm{CaCh} 0,01 \mathrm{~mol} \mathrm{~L}^{-1}$ 
Nas amostras do Latossolo Amarelo ácrico incubado por 42 dias com diferentes teores de água e após três extrações, uma com $\mathrm{CaCl}_{2} \quad 0,01 \mathrm{~mol} \mathrm{\textrm {L } ^ { - 1 }}$ e duas com solvente, a sorção do 2,4-D e do diuron foi maior nos agregados maiores que $150 \mu \mathrm{m}$ (Figuras 13 e 14), o que não esperado já que estas não são os agregados com as maiores quantidades de carbono orgânico (Tabela 6). Porém, nesta fração as partículas estão completamente recobertas com argila e, provavelmente, com matéria orgânica, que é um dos principais agentes cimentantes responsáveis pela estabilização dos agregados, condição que pode ter determinado a maior sorção destes herbicidas. Barriuso \& Koskinen (1996) verificaram que a atrazina foi mais sorvida nas frações maiores que $50 \mu \mathrm{m}$, resultado considerado inesperado, mas uma provável justificativa seria o bioacúmulo nos microrganismos presentes neste agregado. Na amostra do LAw incubada com 2,4D a maior quantidade de água pode ter favorecido a difusão de moléculas do herbicida às superfícies orgânicas, o que aumentou sorção nos agregados menores que $53 \mu \mathrm{m}$ ("silte" e "argila"), sendo maior que $50 \%$ (Figura 13).

Quando o fracionamento físico do LAw ocorreu após o 2,4-D e o diuron

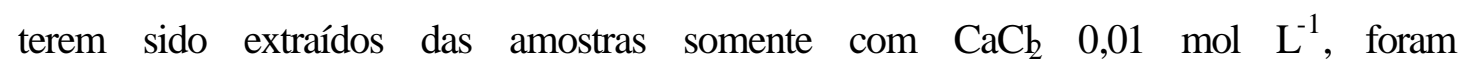
verificadas diferenças na distribuição das moléculas orgânicas nos agregados. Mais de $50 \%$ do 2,4-D ficou sorvido nos agregados maiores que $53 \mu \mathrm{m}$, quando o herbicida foi incubado a 25 e $50 \%$ da capacidade de campo (Figura 15). Porém, nas amostras incubadas com $75 \%$ da capacidade de campo, mais que $50 \%$ do 2,4-D foi sorvido nos agregados menores que $50 \mu \mathrm{m}$. Isto novamente comprova a importância da umidade do solo em quantidade suficiente para que ocorra difusão do pesticida. No caso do diuron, o aumento da quantidade de água aumentou a sorção nos agregados organominerais de 2 a $20 \mu \mathrm{m}$, que foi praticamente de mesma intensidade que para os agregados entre 53 e 150 e maiores que $150 \mu \mathrm{m}$. 


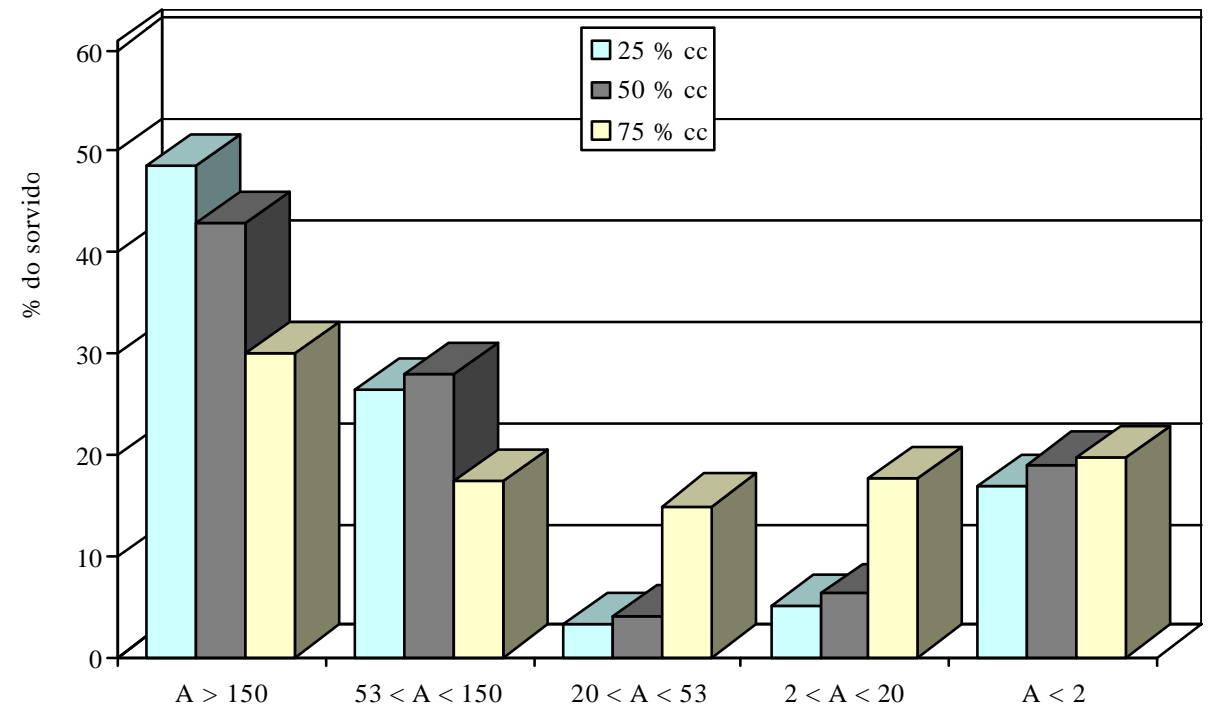

Figura 13 - Porcentagem sorvida do 2,4-D nos agregados $(\mathrm{A}, \mu \mathrm{m})$ do LAw incubado por 42 dias e após uma extração com cloreto e duas com solvente

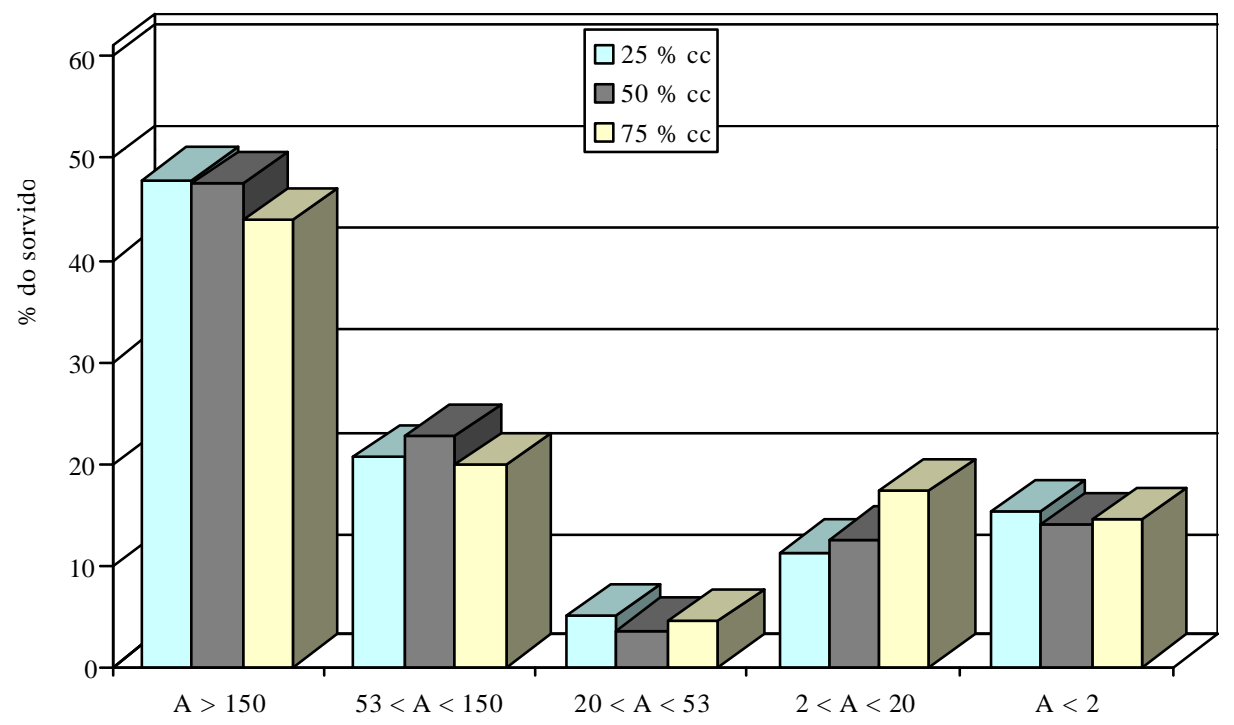

Figura 14 - Porcentagem sorvida do diuron nos agregados (A, $\mu \mathrm{m})$ do LAw incubado por 42 dias e após uma extração com cloreto e duas com solvente 


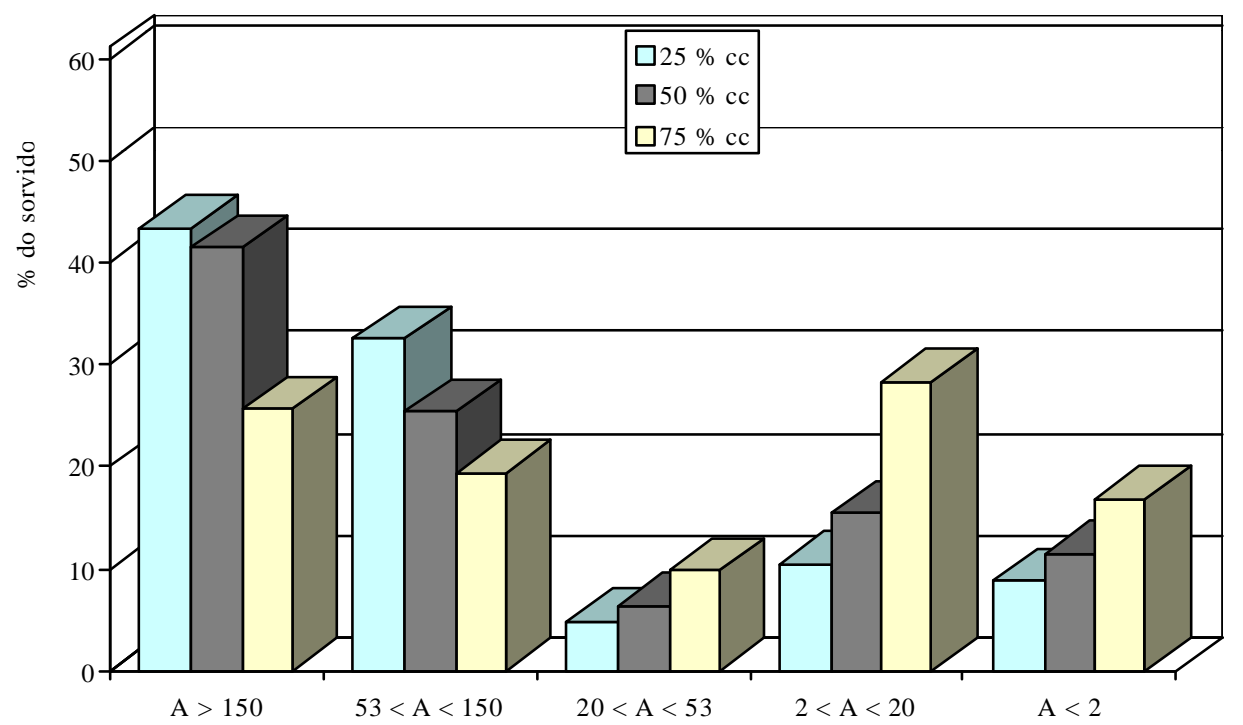

Figura 15 - Porcentagem sorvida do 2,4-D nos agregados $(\mathrm{A}, \mu \mathrm{m})$ do LAw incubado por 42 dias e após três extrações com $\mathrm{CaCh} 0,01 \mathrm{~mol} \mathrm{~L}^{-1}$

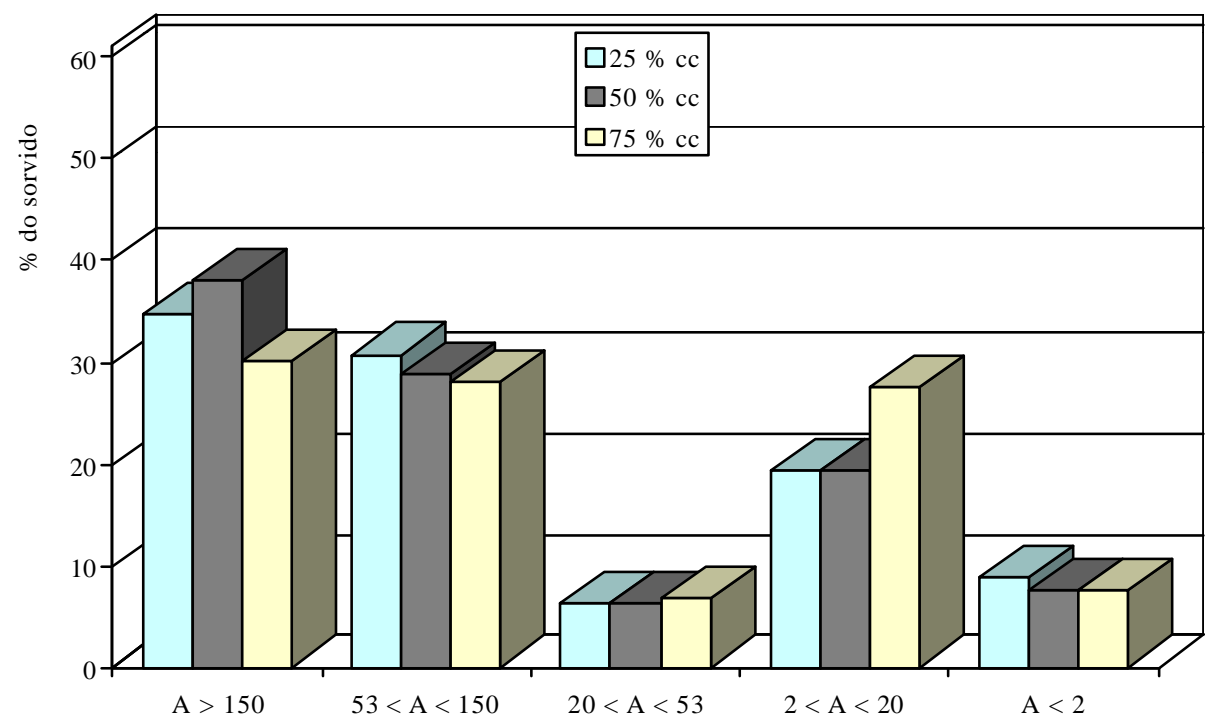

Figura 16 - Porcentagem sorvida do diuron nos agregados $(\mathrm{A}, \mu \mathrm{m})$ do LAw incubado por 42 dias e após três extrações com $\mathrm{CaCh}$ 0,01 mol L ${ }^{-1}$ 
Porém, a sorção nos agregados maiores que $53 \mathrm{~mm}$ continuou superior a $50 \%$ (Figura 16). O diuron é uma molécula polar, por isso tem afinidade com os sítios hidrofílicos presentes no húmus (Roy et al., 2000). Seria esperado que a sorção aos agregados menores que $53 \mu \mathrm{m}$ fossem maior do que ocorreu, mas a água presente em maior quantidade pode ter competido com as moléculas pelos sítios hidrofílicos. No Latossolo Vermelho ácrico de Uberlândia (LVw-1), o aumento da umidade também proporcionou maior difusão das moléculas orgânicas de 2,4 D e diuron para o interior dos microporos (Brusseau, 1991) até as superfícies sorvedoras, nas quais podem encontrar sítios hidrofóbicos, hidrofílicos e com carga positiva, o que favoreceu o aumento na sorção dos herbicidas aos agregados de menor tamanho. Porém, o efeito mais pronunciado foi nos de diâmetro entre 2 e $20 \mu \mathrm{m}$ (Figuras 17 e 18), que possuem o maior conteúdo de carbono (Tabela 6), o que indica que há maior presença de sítios hidrofóbicos e hidrofílicos nestes agregados. Nas amostras do Latossolo Vermelho ácrico de Canoinhas (LVw-2), mesmo o 2,4-D apresentando um aumento da sorção nos agregados entre 2 e 20 $\mu \mathrm{m}$ provenientes das amostras incubadas a $75 \%$ da capacidade de campo, a maior parte das moléculas foram sorvidas pelos agregados maiores que $53 \mu \mathrm{m}$ (Figura 19), principalmente no caso do diuron (Figura 20). Neste solo, a quantidade razoável de carbono nos agregados maiores que $150 \mu \mathrm{m}$ (Tabela 6) e a maior quantidade destes agregados pode ter determinado maior número de sítios de sorção, em comparação com os agregados menores que $53 \mu \mathrm{m}$.

O alto grau de intemperismo do LAw, do LVw-1 e do LVw-2 proporcionou uma quantidade de óxidos de ferro e alumínio suficiente para que, em conjunto com a matéria orgânica do solo, garantissem condições ideais para a cimentação dos microagregados e partículas do solo, o que aumentou a estabilidade dos agregados em água. 


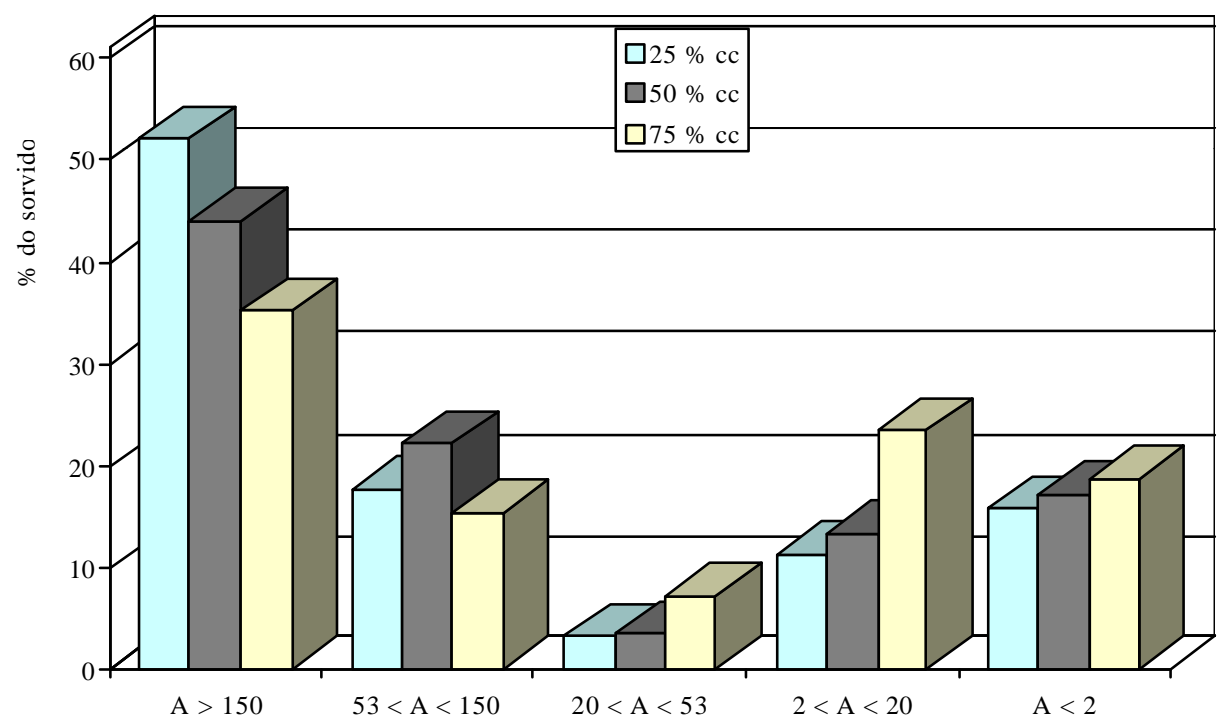

Figura 17 - Porcentagem sorvida do 2,4-D nos agregados $(\mathrm{A}, \mu \mathrm{m})$ do LVw-1 incubado por 42 dias e após três extrações com $\mathrm{CaCl}$ 0,01 $\mathrm{mol} \mathrm{L}^{-1}$

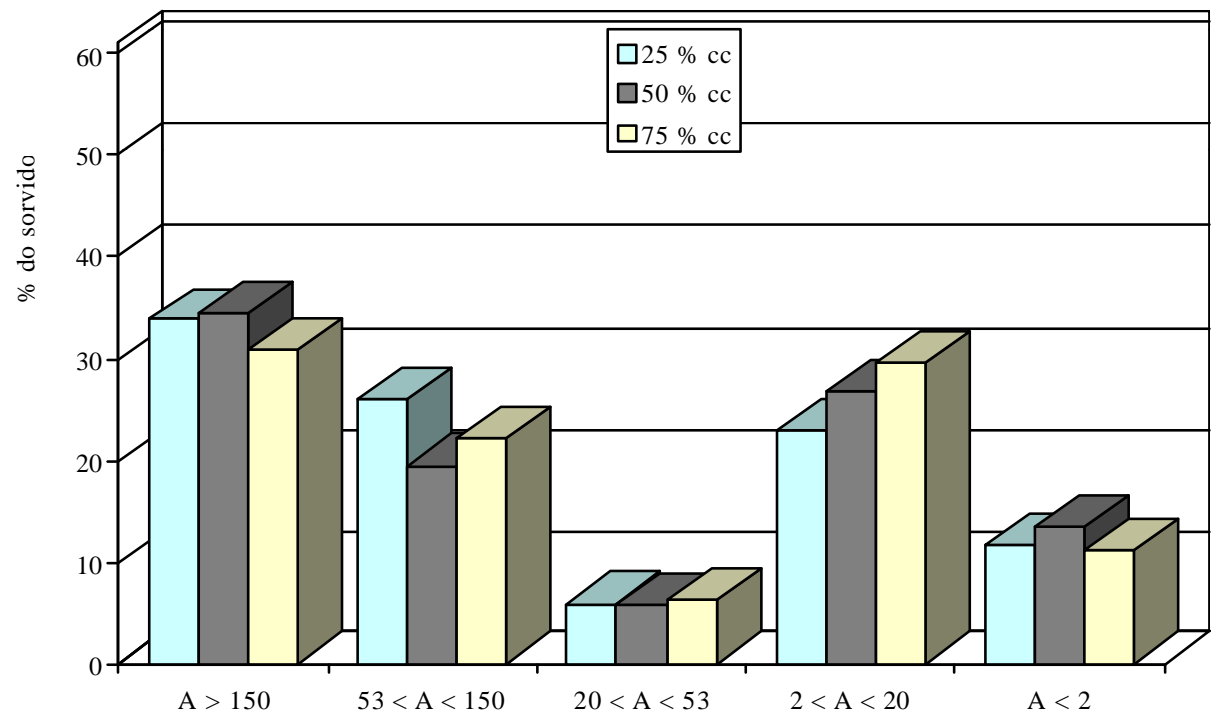

Figura 18 - Porcentagem sorvida do diuron nos agregados $(\mathrm{A}, \mu \mathrm{m})$ do LVw-1 incubado por 42 dias e após três extrações com $\mathrm{CaCh}_{2} 0,01 \mathrm{~mol} \mathrm{~L}^{-1}$ 


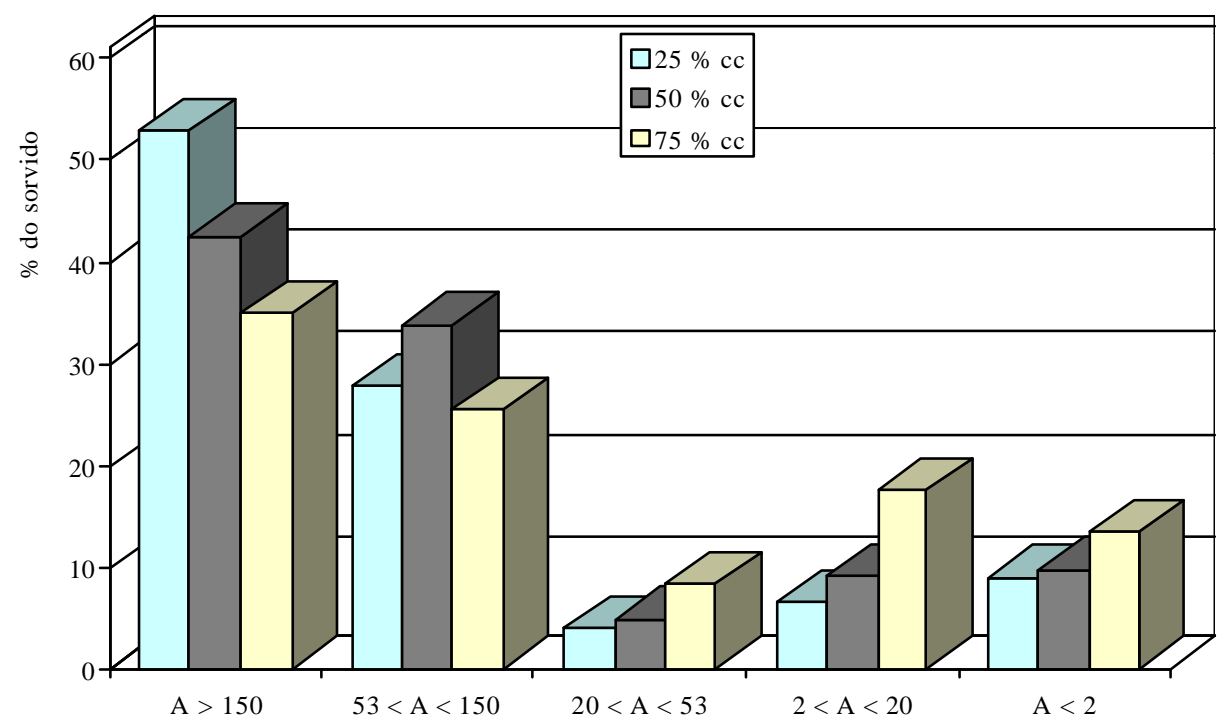

Figura 19 - Porcentagem sorvida do 2,4-D nos agregados (A, $\mu \mathrm{m})$ do LVw-2 incubado por 42 dias e após três extrações com $\mathrm{CaCl}$ 0,01 $\mathrm{mol} \mathrm{L}^{-1}$

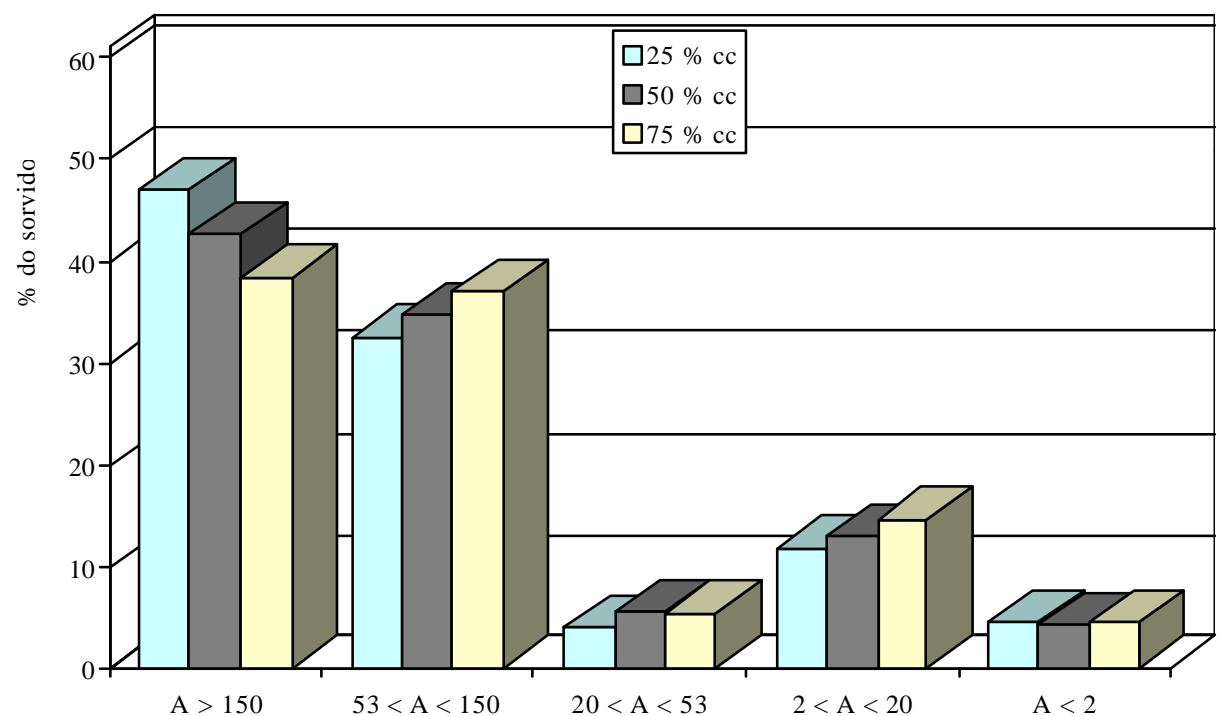

Figura 20 - Porcentagem sorvida do diuron nos agregados $(\mathrm{A}, \mu \mathrm{m})$ do LVw-2 incubado por 42 dias e após três extrações com $\mathrm{CaCh} 0,01 \mathrm{~mol} \mathrm{~L}^{-1}$ 
Para verificar a possibilidade de os herbicidas serem extraídos do solo durante a separação dos agregados, foi realizado o monitoramento da radioatividade emitida na água descartada, que indicou uma possível "remobilização" das moléculas dos herbicidas. Este tipo de monitoramento não foi verificado em nenhum dos textos revisados. Nos trabalhos, a extração dos herbicidas é feita exaustivamente (Barriuso \& Koskinen, 1996) até que os autores verifiquem que não haja emissão de radioatividade. A "remobilização" dos herbicidas durante $\mathrm{o}$ fracionamento foi maior nas amostras incubadas com os menores teores de água (Figura 21), o que pode ser um indicativo de que as moléculas presentes nas amostra com maior grau de umidade estavam mais fortemente sorvidas.

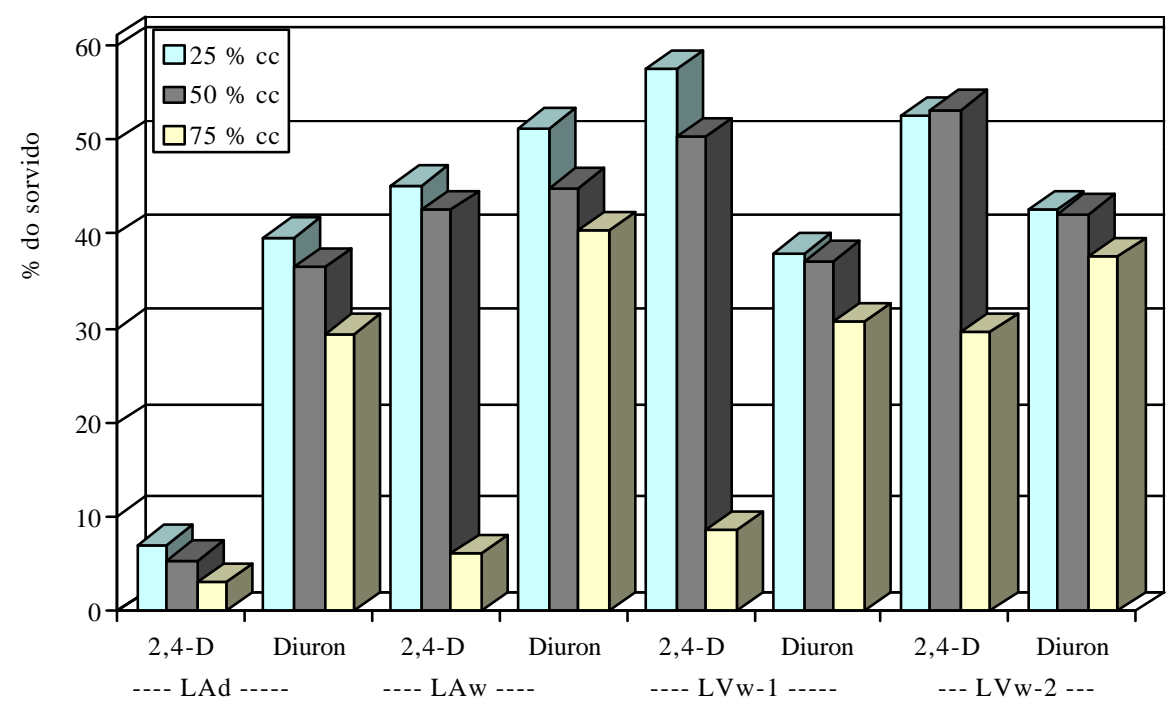

Figura 21 - Porcentagem extraída do 2,4-D e do diuron em relação à quantidade sorvida durante a separação dos agregados em água

O fracionamento físico dos agregados organominerais do LAd e LAw, após as extrações com $\mathrm{CaCh}_{2}$ 0,01 mol $\mathrm{L}^{-1}$ e com solvente, mostrou que a solução usada nas extrações e as agitações e centrifugações podem ter tido importante 
contribuição na dispersão dos agregados, quando se comparam com os resultados do fracionamento do mesmo solo sem as extrações com a solução (Figuras 22, 23, 24 e 25). Deste modo, pode-se questionar os estudos da dinâmica de pesticidas nos agregados organominerais após exaustivas extrações antes de iniciar o fracionamento físico, pois neste caso não haverá agregados e sim partículas de areia. No método padrão de análise da distribuição do tamanho de partículas do solo, as amostras podem ser expostas a pré-tratamentos químicos para remover matéria orgânica, óxidos, carbonatos e outros agentes cimentantes antes de iniciar a dispersão. Porém, se a intenção é estudar as interações que ocorrem com os complexos organominerais intactos, nenhum tratamento químico dispersivo é permitido (Christensen, 1992). Nos Latossolos Vermelhos ácricos (LVw-1 e LVw-2), a dispersão aumentou após as extrações dos herbicidas com $\mathrm{CaCh}_{2}$, porém, ao contrário dos LAd e LAw, os agregados "silte" (entre 2 e $53 \mu \mathrm{m}$ ) e "areia fina" (entre 53 e $150 \mu \mathrm{m}$ ) foram os que mais aumentaram, o que pode ser explicado pela maior quantidade de matéria orgânica (Tabela 1) e óxido de ferro (Tabela 2) destes solos, atributos que causam maior agregação e menor dispersão. A redução no cultivo do solo, principalmente pelo emprego do sistema de plantio direto, tende a aumentar a quantidade de material orgânico na camada superficial do solo, o que aumenta o grau de agregação do solo. Deste modo, não haverá ou será reduzido o escorrimento superficial, o que concomitantemente evitará o carreamento de pesticidas. 


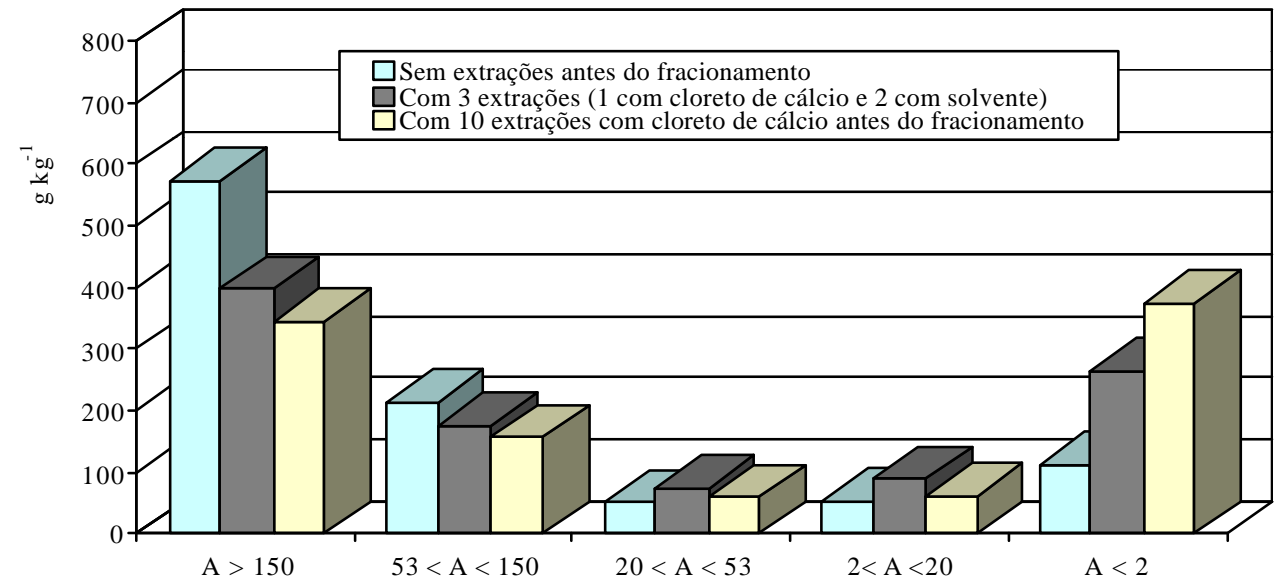

Figura 22 - Quantidade dos agregados (A, $\mu \mathrm{m}$ ) organominerais do LAd sem as extrações e com extrações antes do fracionamento físico

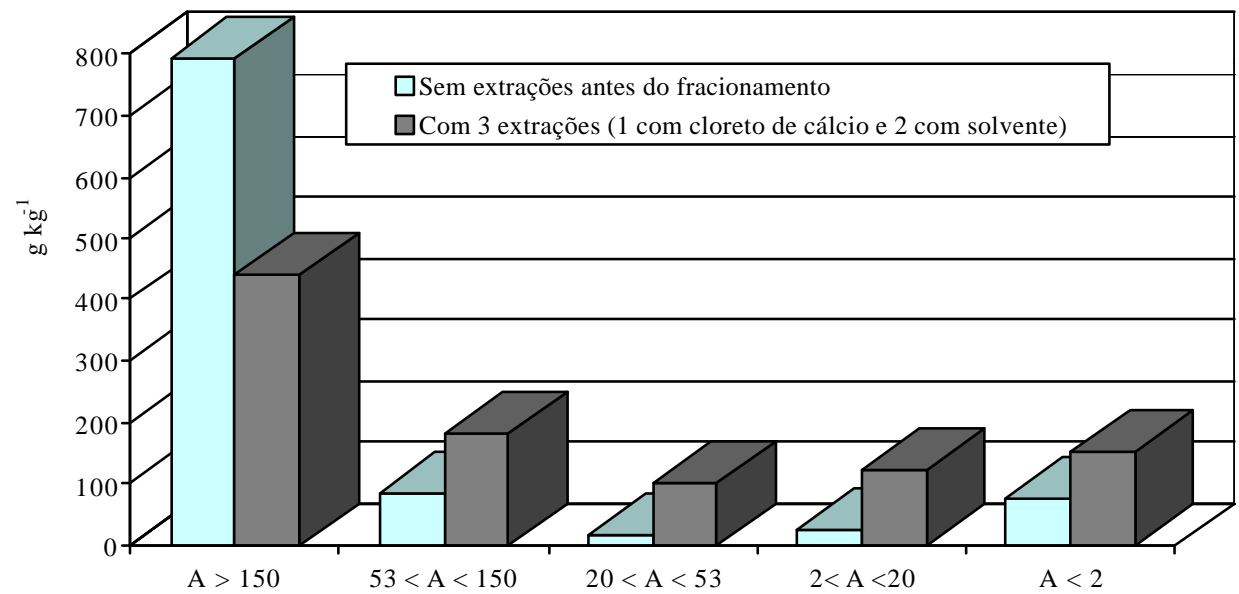

Figura 23 - Quantidade dos agregados (A, $\mu \mathrm{m}$ ) organominerais do LAw sem as extrações e com extrações antes do fracionamento físico 


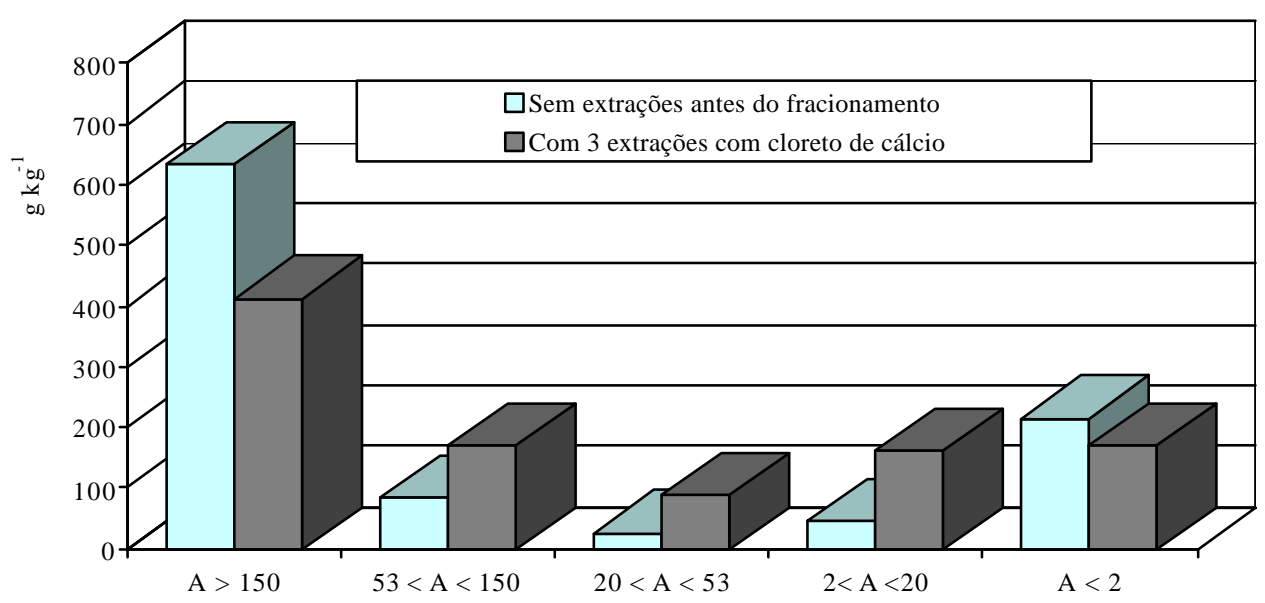

Figura 24 - Quantidade dos agregados $(\mathrm{A}, \mu \mathrm{m})$ organominerais do LVw-1 sem as extrações e com extrações antes do fracionamento físico

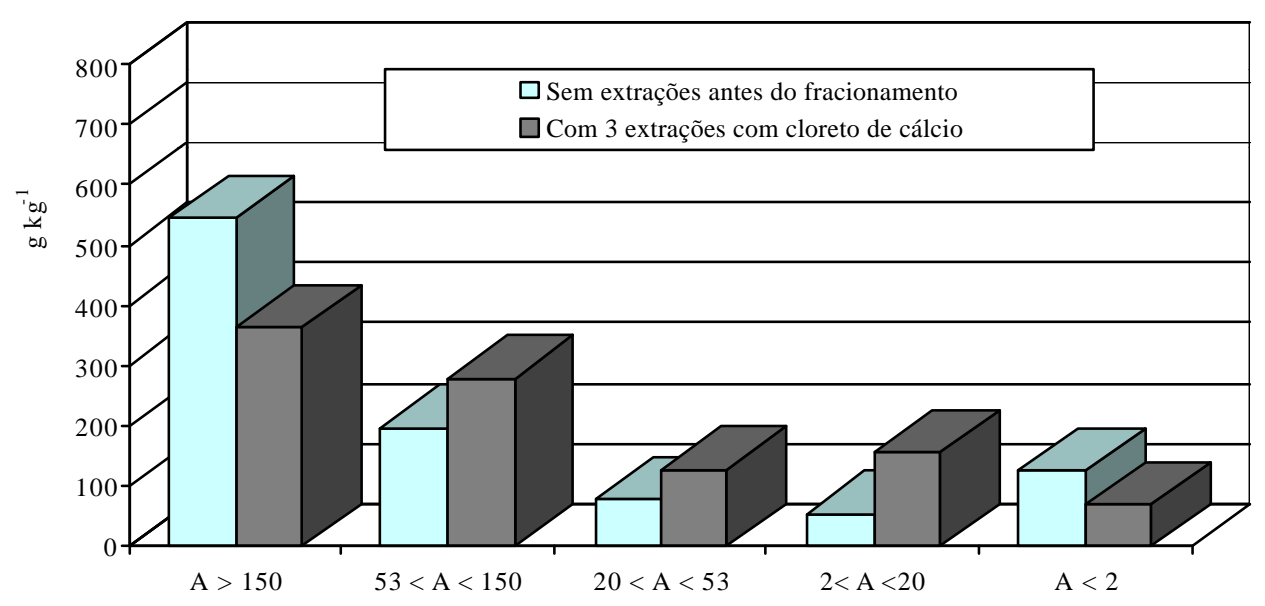

Figura 25 - Quantidade dos agregados $(\mathrm{A}, \mu \mathrm{m})$ organominerais do LVw-2 sem as extrações e com extrações antes do fracionamento físico

\subsection{Grau de humificação}

O Latossolo Amarelo distrófico apresentou o maior grau de humificação em relação aos Latossolos Vermelhos ácricos (Tabela 7). Este resultado pode ser devido ao fato de o LAd ter sido coletado em uma área cultivada, no qual os 
macroagregados presentes na camada superficial do solo são quebrados, e a matéria orgânica não humificada fica exposta para ser oxidada (Tisdall \& Oades, 1982), o que aumenta sua degradação. Solos de áreas não cultivadas, como a do LVw-2, normalmente apresentam maior quantidade de matéria orgânica, mas com menor grau de humificação, já que sem o revolvimento os agregados não são quebrados, o que evita a oxidação de material orgânico menos humificado. A maior quantidade de areia neste solo (Tabela 3) pode ter facilitado o maior grau de humificação da matéria orgânica.

Tabela 7. Grau de humificação e área do espectro obtido por fluorescência dos agregados e dos solos

\begin{tabular}{|c|c|c|c|c|c|c|}
\hline & --------- & ---- Agreg & os organomin & is $(\mu \mathrm{m})--$ & ----- & Solo \\
\hline Solo & $\mathrm{A}>150$ & $53<\mathrm{A}<150$ & $20<\mathrm{A}<53$ & $2<\mathrm{A}<20$ & $\mathrm{~A}<2$ & Total \\
\hline LAd & 358,7 & 789,0 & 336,2 & 184,0 & 273,6 & 308,9 \\
\hline LAw & 359,0 & 397,0 & 271,1 & 333,1 & 390,7 & 365,5 \\
\hline LVw-1 & 163,7 & 229,8 & 197,6 & 96,1 & 177,4 & 181,2 \\
\hline LVw-2 & 156,9 & 222,5 & 205,6 & 143,7 & 116,0 & 174,7 \\
\hline LAd & 468,8 & 520,7 & 494,9 & 550,6 & 513,8 & 481,0 \\
\hline LAw & 733,2 & 783,3 & 977,5 & 791,2 & 811,6 & 773,1 \\
\hline LVw-1 & 494,8 & 518,8 & 589,3 & 529,1 & 476,0 & 522,5 \\
\hline LVw-2 & 543,2 & 502,1 & 510,4 & 677,0 & 530,0 & 569,1 \\
\hline
\end{tabular}

LAd = Latossolo Amarelo distrófico, LAw = Latossolo Amarelo ácrico, LVw-1 = Latossolo Vermelho ácrico (Uberlândia) e LVw-2 = Latossolo Vermelho ácrico (Canoinhas). Grau de humificação = Área do espectro/teor de carbono.

A posição do solo no relevo pode interferir nos seus atributos, o que pôde ser verificado entre o LAw e o LVw-1. Estes solos estavam localizados no ápice da chapada Sul-Americana, porém o LAw se localizava em uma área de 
subsidência, onde o acúmulo de água era constante. Dessa forma, o $\mathrm{Fe}$ encontrou condições para redução e conseqüente solubilização, o que explica sua menor quantidade em relação ao LVw-1 (Tabela 2). Deste modo, menos ferro havia para cimentar os macroagregados, e a matéria orgânica pôde ser mais facilmente oxidada e humificada, o que pode ter determinado no maior grau de humificação do LAw (Tabela 7).

O grau de humificação foi maior nos agregados organominerais entre 53 e $150 \mu \mathrm{m}$ de todos os solos (Tabela 7), o que não era esperado ao considerar o que normalmente é discutido em referências bibliográficas. De maneira geral, os agregados que se apresentam mais humificados são os menores que $50 \mu \mathrm{m}$ ("silte" e "argila") (Christensen, 1992; Tisdall \& Oades, 1982). Porém, exceto no LAd, a sorção dos herbicidas foi maior nos agregados maiores que $53 \mu \mathrm{m}$, o que poderia ser consequiência do maior grau de humificação, já que a quantidade de carbono orgânico foi menor nestes agregados (Tabela 6). Entretanto, a diferença não foi tão pronunciada a ponto de justificar os resultados de sorção nestes solos.

Após se verificar que a maior quantidade de carbono orgânico dos agregados menores que $53 \mu \mathrm{m}$ não determinava o maior grau de humificação e nem a maior sorção dos herbicidas, foi considerada a possibilidade de definir alguns atributos que pudessem estimar a sorção nos agregados do solo. Como uma primeira aproximação, a estimativa da sorção foi obtida a partir de uma relação de proporcionalidade entre os produtos do grau de humificação, quantidade de carbono orgânico e quantidade dos agregados. A estimativa da sorção foi fundamental para explicar a maior sorção dos herbicidas nos agregados maiores que $53 \mu \mathrm{m}$. Assim, a sorção nestes agregados depende do quanto a matéria orgânica está humificada, da quantidade de carbono orgânico e da quantidade dos agregados (Figuras 26, 27, 28, 29, 30 e 31). Os resultados confirmam a importância da difusão no transporte das moléculas para os 
microporos do solo e para os sítios de adsorção da matriz orgânica (Brusseau et al., 1991), pois o aumento do teor de água na amostra, principalmente a $75 \%$ da capacidade de campo, determinou o aumento considerável na sorção dos herbicidas aos agregados de diâmetro entre 2 a $20 \mu \mathrm{m}$ (Figuras 26, 27, 28, 30 e 31). O maior incremento na sorção do 2,4-D nestes agregados, quando havia mais água no solo, em comparação ao diuron, pode ser explicado pela competição das moléculas polares deste herbicida com a água por sítios hidrofílicos da matéria orgânica. A estimativa da sorção pela relação de proporcionalidade entre os produtos do grau de humificação, da quantidade de carbono orgânico e da quantidade de agregados, não se aplicou ao LAd (Figuras 32 e 33). Neste solo, dos atributos relacionados, somente a quantidade de carbono orgânico (Tabela 6) teve maior influência na sorção dos herbicidas (Figuras 11 e 12), o que pode ser devido ao fato de ele ser o único solo que apresentou quase que toda sua fração maior que $53 \mu \mathrm{m}$ composta por partículas de areia. Com isso o número de sítios de sorção dos herbicidas deve ter sido reduzido.

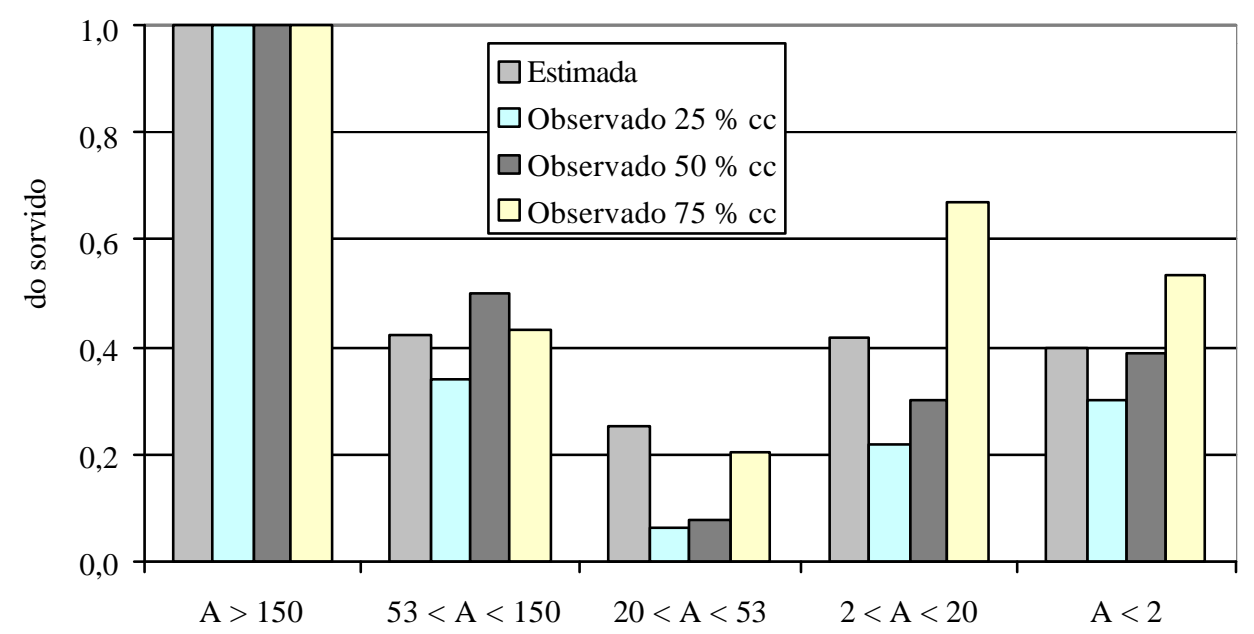

Figura 26 - Estimativa da sorção do 2,4-D nos agregados $(\mathrm{A}, \mu \mathrm{m})$ do LVw-1 em relação ao observado 


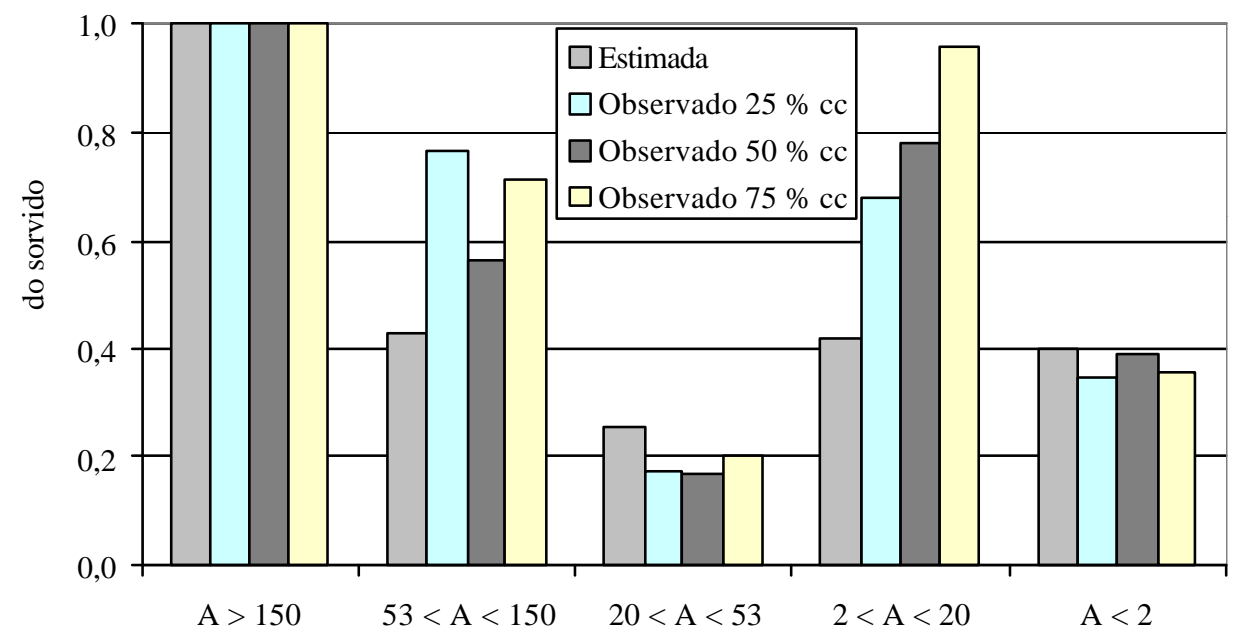

Figura 27 - Estimativa da sorção do diuron nos agregados $(\mathrm{A}, \mu \mathrm{m})$ do LVw-1 em relação ao observado

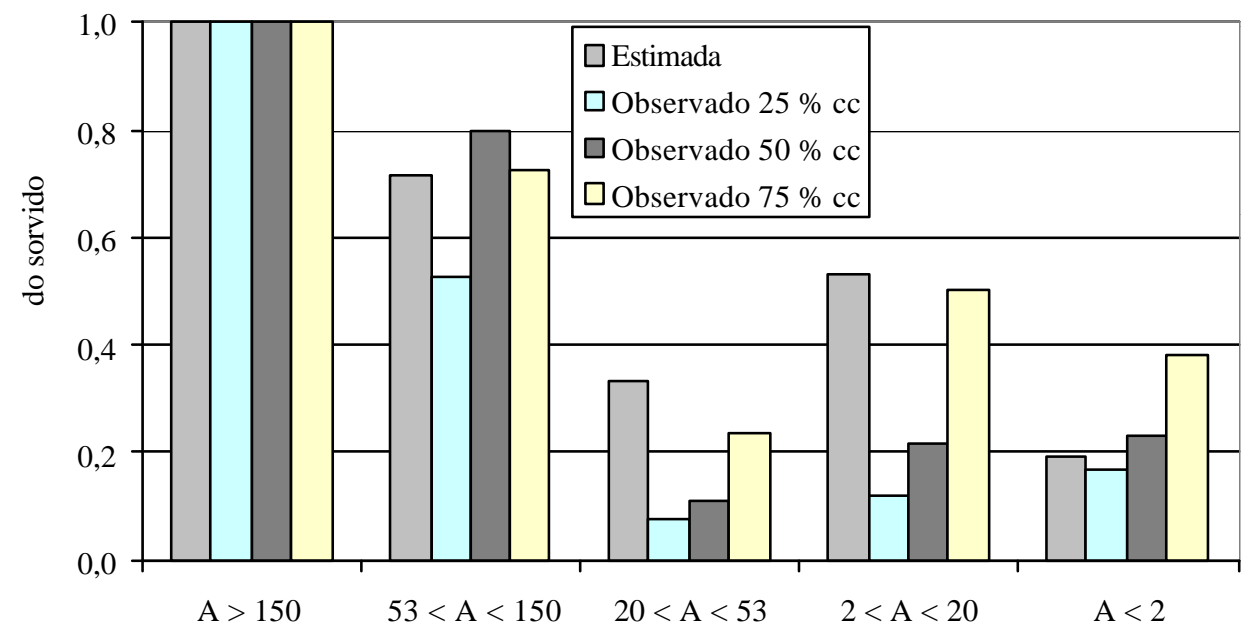

Figura 28 - Estimativa da sorção do 2,4-D nos agregados $(\mathrm{A}, \mu \mathrm{m})$ do LVw-2 em relação ao observado 


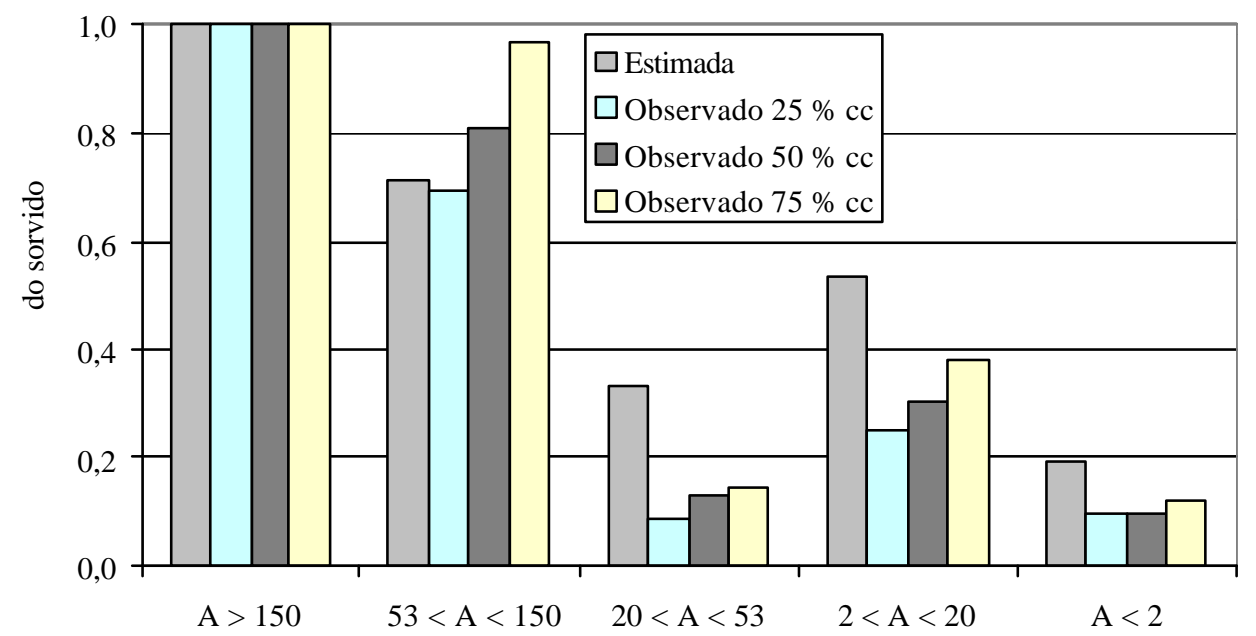

Figura 29 - Estimativa da sorção do diuron nos agregados (A, $\mu \mathrm{m})$ do LVw-2 em relação ao observado

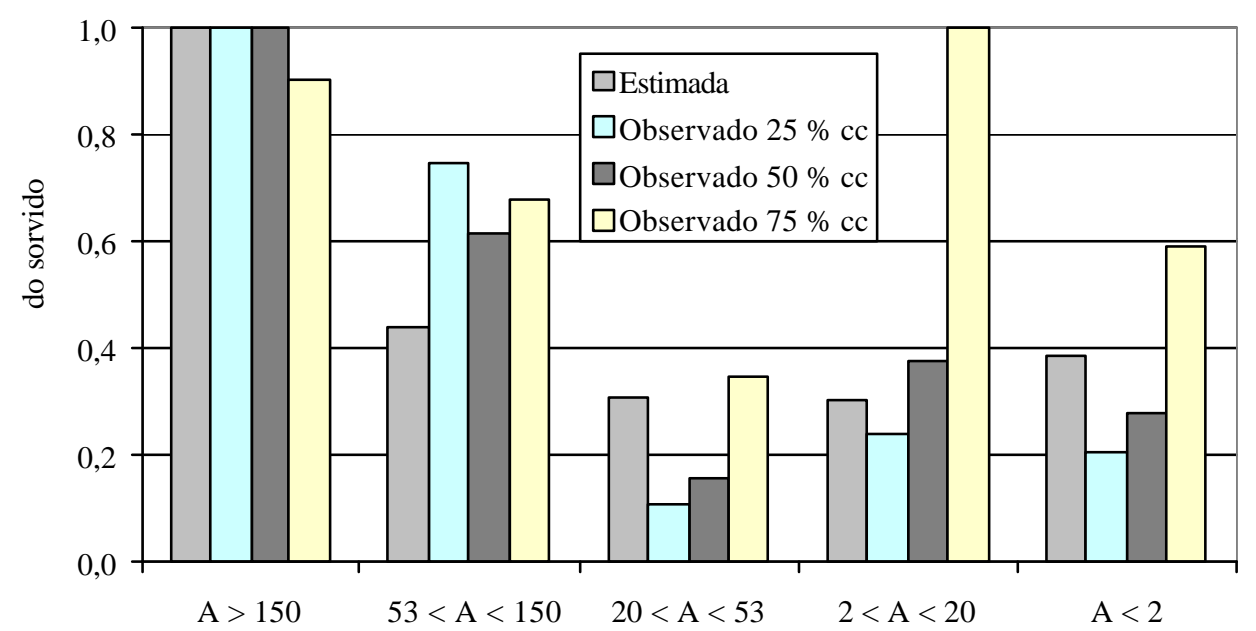

Figura 30 - Estimativa da sorção do 2,4-D nos agregados (A, $\mu \mathrm{m})$ do LAw em relação ao observado 


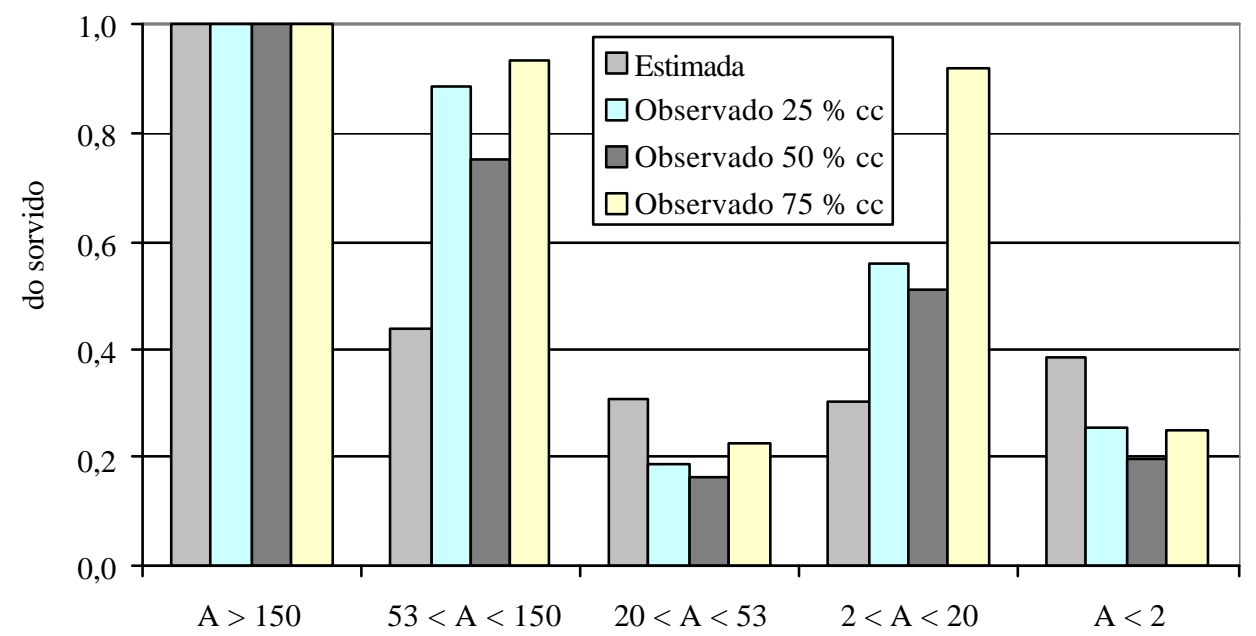

Figura 31 - Estimativa da sorção do diuron nos agregados $(\mathrm{A}, \mu \mathrm{m})$ do LAw em relação ao observado

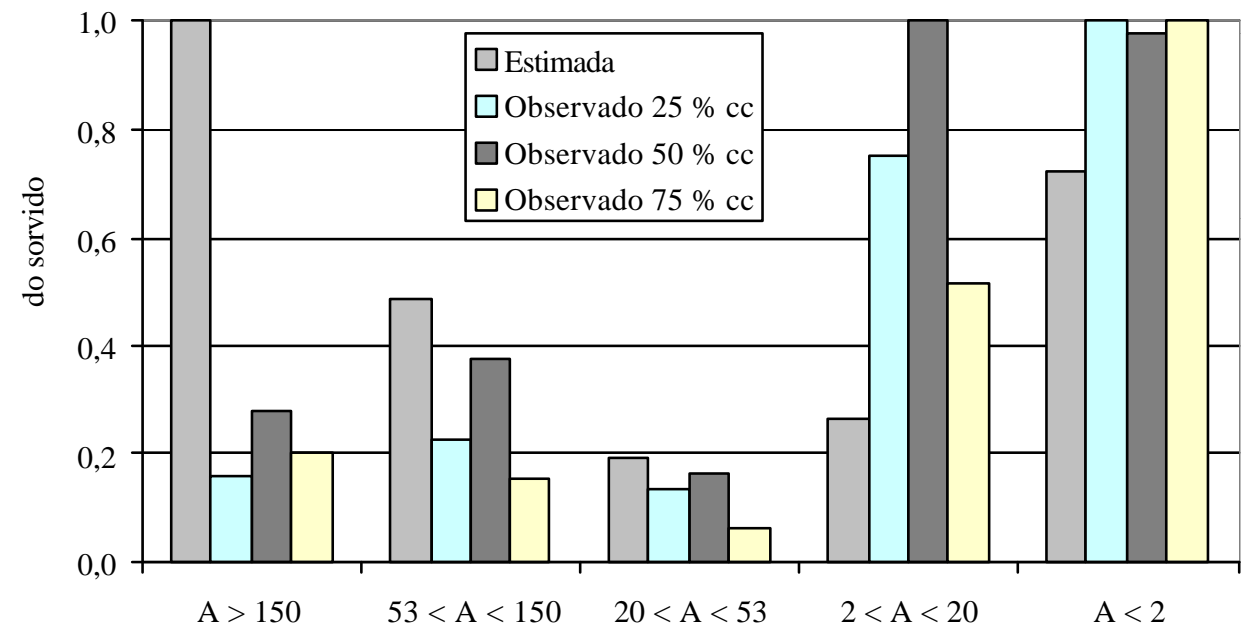

Figura 32 - Estimativa da sorção do 2,4-D nos agregados $(\mathrm{A}, \mu \mathrm{m})$ do LAd em relação ao observado 


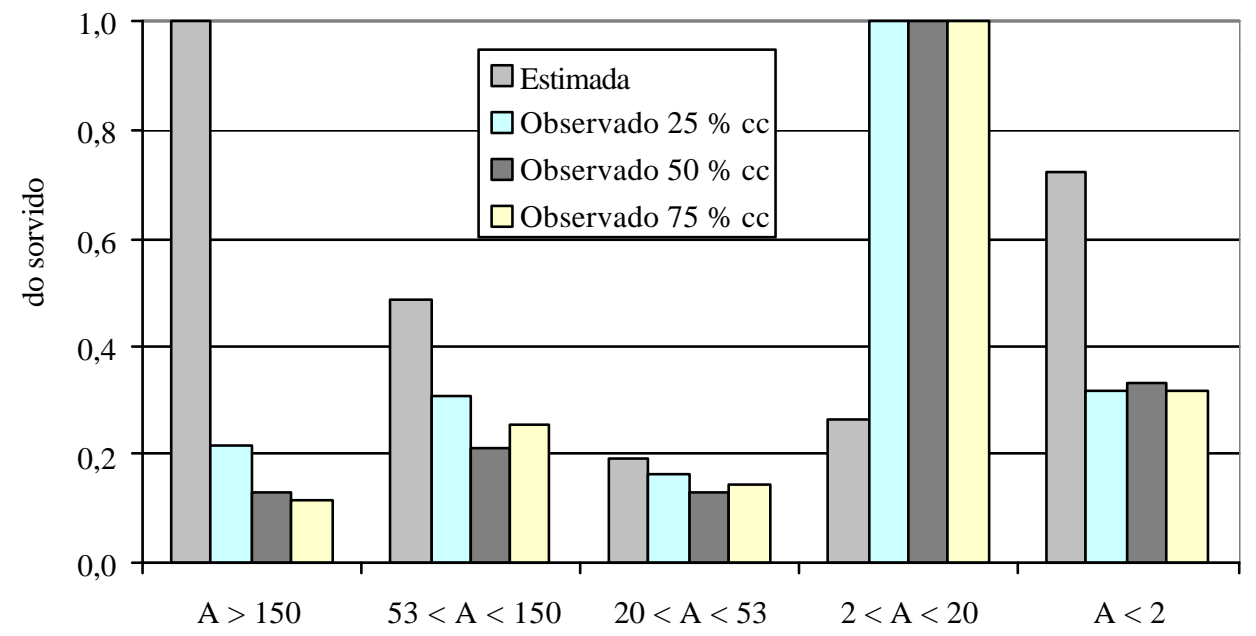

Figura 33 - Estimativa da sorção do diuron nos agregados $(\mathrm{A}, \mu \mathrm{m})$ do LAd em relação ao observado 


\section{CONCLUSÕES}

A mineralização dos herbicidas foi maior nas amostras com maior teor de água, sendo que o 2,4-D foi mais mineralizado que o diuron.

As moléculas dos herbicidas foram mais extraídas com solução de cloreto de cálcio nas amostras com menor grau de umidade, e a sorção dos compostos orgânicos foi maior nas amostras com maior teor de água, o que realça a importância do mecanismo de difusão.

No Latossolo Amarelo distrófico, a sorção do 2,4-D e diuron foi maior nos agregados menores que $53 \mu \mathrm{m}$, o que confirmou a importância da matéria orgânica.

A estimativa da sorção em função do grau de humificação, quantidade de carbono orgânico e quantidade dos agregados determinou a importância destes atributos na maior sorção dos herbicidas nos agregados maiores que $53 \mu \mathrm{m}$ dos Latossolos Amarelo ácrico e dos Latossolos Vermelhos ácricos. Esta estimativa da sorção também confirmou a importância da umidade na sorção dos herbicidas nos agregados de diâmetro entre 2 e $20 \mu \mathrm{m}$. 
ANEXOS 
Espectros de Fluorescência

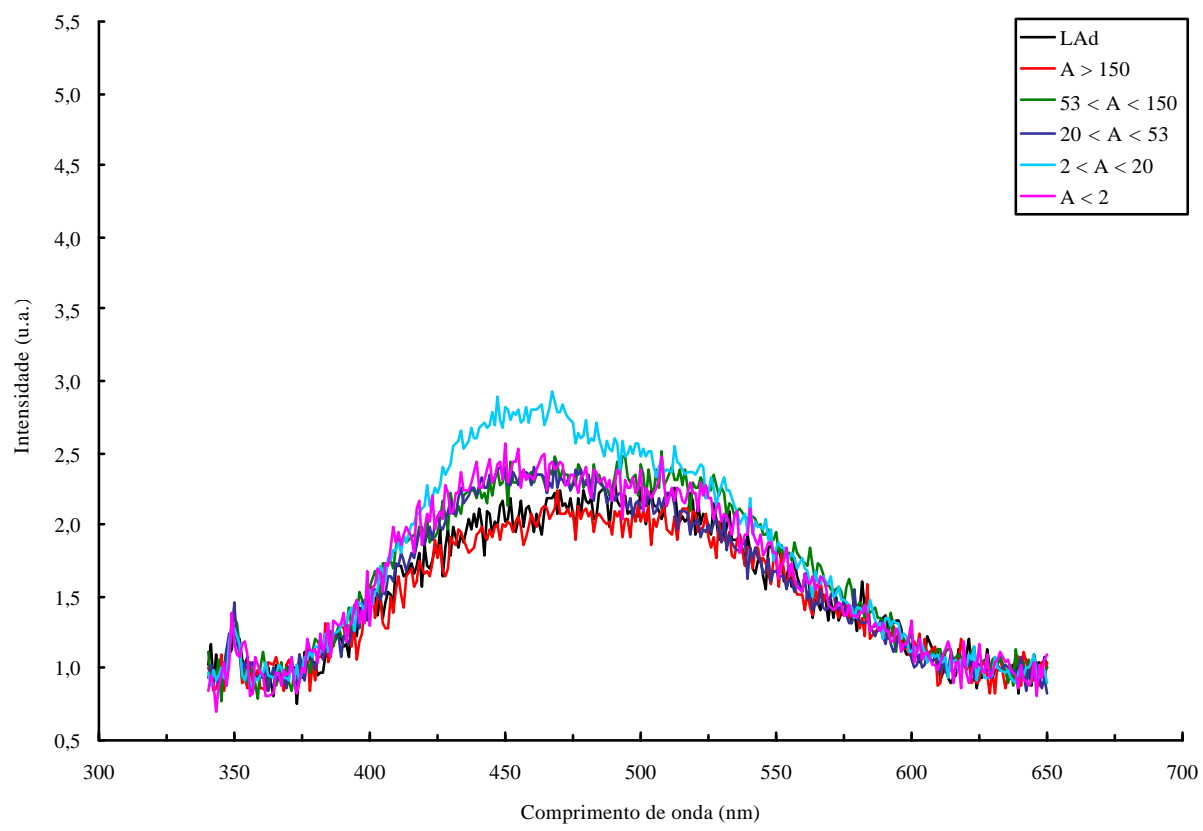

Figura 34 - Espectros de fluorescência do Latossolo Amarelo distrófico (LAd) e de seus agregados organominerais $(\mathrm{A}, \mu \mathrm{m})$

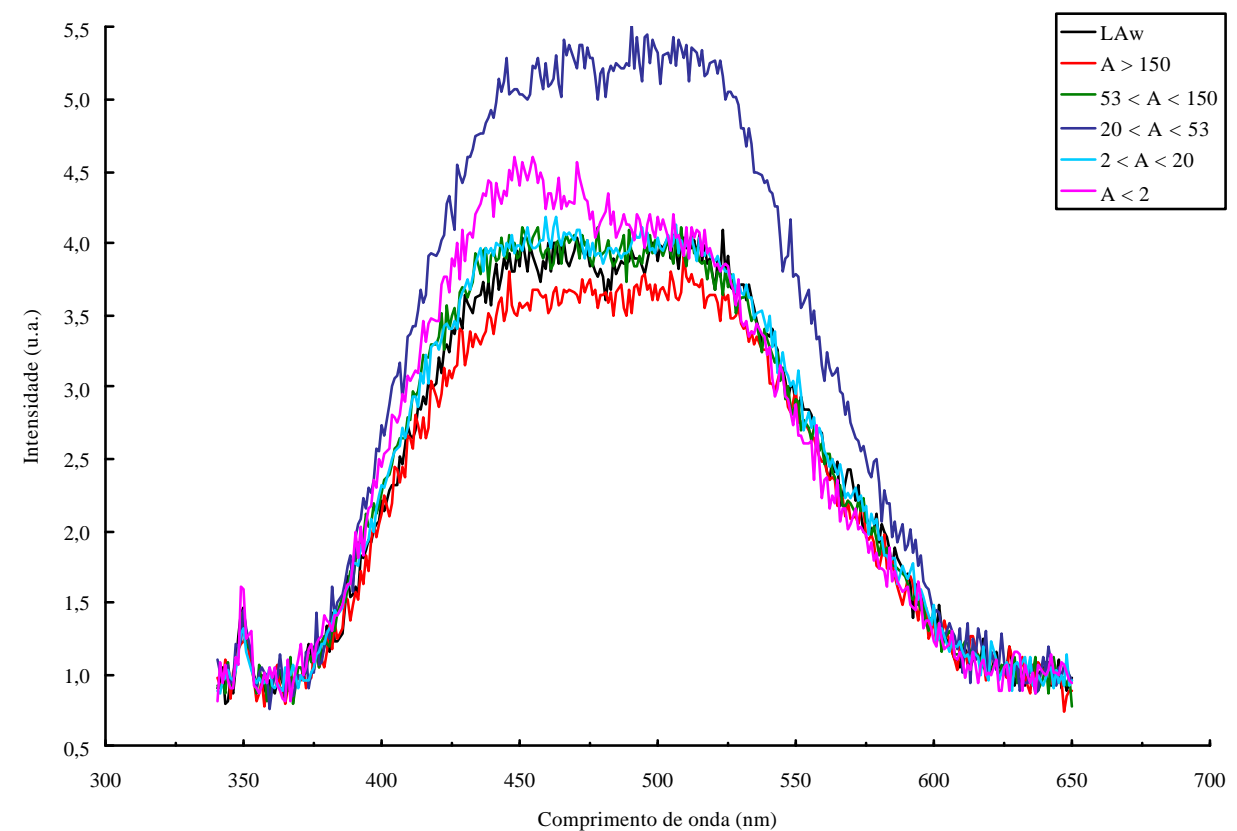

Figura 35 - Espectros de fluorescência do Latossolo Amarelo ácrico (LAw) e de seus agregados organominerais $(\mathrm{A}, \mu \mathrm{m})$ 


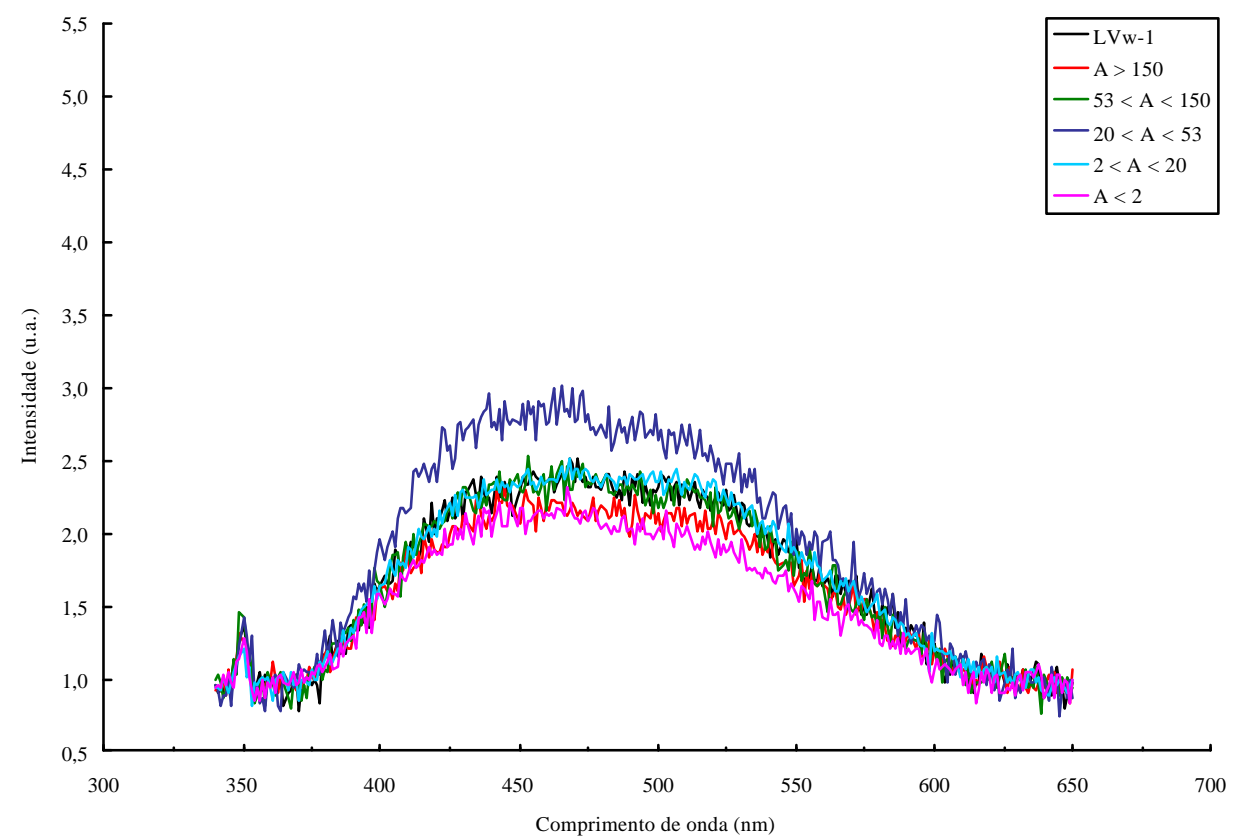

Figura 36 - Espectros de fluorescência do Latossolo vermelho ácrico (LVw-1, Uberlândia) e de seus agregados organominerais $(\mathrm{A}, \mu \mathrm{m})$

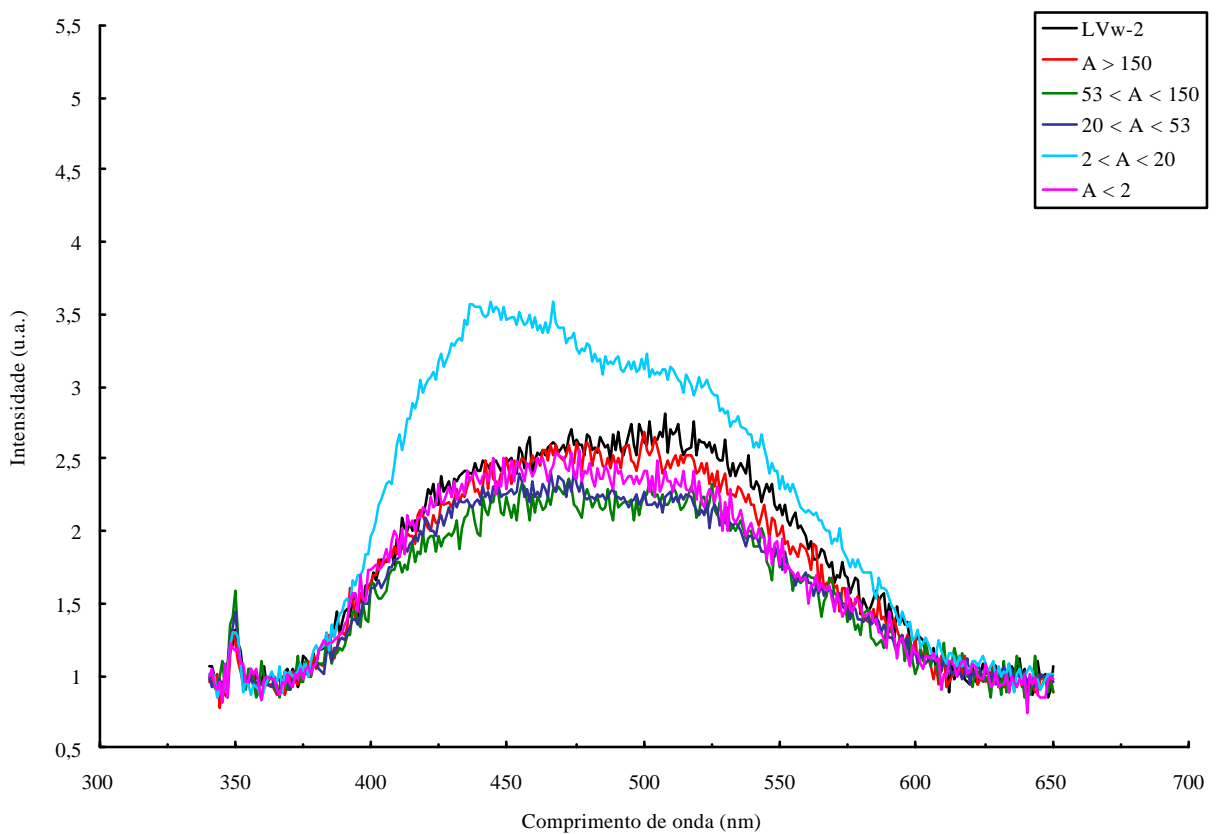

Figura 37 - Espectros de fluorescência do Latossolo vermelho ácrico (LVw-2, Canoinhas) e de seus agregados organominerais $(\mathrm{A}, \mu \mathrm{m})$ 


\section{REFERÊNCIAS BIBLIOGRÁFICAS}

ALLEONI, L.R.F. Atributos eletroquímicos de solos ácricos do norte paulista. Piracicaba, 1992. 132p. Dissertação (Mestrado) - Escola Superior de Agricultura “Luiz de Queiroz”, Universidade de São Paulo.

ANDREUX, F.; SCHIAVON, M.; BERTIN, G.; PORTAL, J.M.; BARRIUSO, E. The usefulness of humus fractionation methods in studies about the behaviour of pollutants in soils. Toxicology Environmental and Chemistry, v.31/32, p.29-38, 1991.

ANGERS, D.A.; MEHUYS, G.R. Barley and alfalfa cropping effects on carbohydrate contents of a clay soil and its size fractions. Soil Biology and Biochemistry, v.22, p.285-288, 1990.

BALESDENT, J.; MARIOTTI, A.; GUILLET, B. Natural 13C abundance as a tracer for studies of soil organic matter dynamics. Soil Biology and Biochemistry, v.19, p.25-30, 1987.

BARRIUSO, E.; KOSKINEN, W.C. Incorporating nonextractable atrazine residues into soil size fractions as a function of time. Soil Science Society of America Journal, v.60, p.150-157, 1996. 
BARRIUSO, E.; SCHIAVON, M.; ANDREUX, F.; PORTAL, J.M. Localization of atrazine non-extractable (bound) residues in soil size fractions. Chemosphere, v.22, p.1131-1140, 1991.

BARTOLI, F.; PATERSON, E.; PHILIPPY, R.; DEMAI, J.J.; DOIRISSE, M. Aggregation in soils with small amounts of swelling clays. II. Chemistry and surface properties of Na-resin stable soil aggregates. Journal of Soil Science, v.39, p.617-628, 1988 .

BAYER, C.; MARTIN-NETO, L.; MIELNICZUK, J.; CERETTA, C.A. Effect of no-till cropping systems on soil organic matter in a sandy clay loam acrisol from southern Brazil monitored by electron spin resonance and nuclear magnetic resonance. Soil and Tillage Research, v.53, p.95-104, 2000.

BELMOUNDEN, M.; ASSABBANE, A.; ICHOU, Y.A. Adsorption characteristics of a phenoxy acetic acid herbicide on activated carbon. Journal of Environmental Monitoring, v.2, p.257-260, 2000.

BENOIT, P.; BARRIUSO, E.; BERGHEAUD, V.; ETÉVANT, V. Binding capacities of different soil size fractions in the formation of herbicide-bound residues. Agronomie, v.20, p.505-512, 2000.

BRUSSEAU, M.L.; JESSUP, R.E.; RAO, P.S.C. Nonequilibrium sorption of organic chemicals: elucidating of rate limiting process. Environmental Science and Technology, v.25, p.134-142, 1991. 
CAMARGO, O.A.; MONIZ, A.C.; JORGE, J.A.; VALADARES, J.M.S. Métodos de análise química, mineralógica e física de solos do Instituto Agronômico de Campinas. Campinas: IAC, 1986. 94 p. (IAC. Boletim Técnico, 106).

CATROUX, G.; SCHNITZER, M. Chemical, spectroscopic, and biological characteristics of the organic matter in particle size fractions separated from an aquoll. Soil Science Society of America Journal, v.51, p.1200-1207, 1987.

CONNOLLY, R.D.; KENNEDY, I.R.; SILBURN, D.M.; SIMPSON, B.N.; FREEBAIM, D.M. Simulating endosulfan transport in runoff from cotton fields in Australia with the GLEAMS model. Journal of Environmental Quality, v.30, p.702-703, 2001.

CHRISTENSEN, B.T. Physical fractionation of soil and organic matter in primary particle size and density separates. Advances in Soil Science, v.20, p.1-90, 1992.

CHRISTENSEN, B.T.; SORENSEN, L.H. The distribution of native and labelled carbon between soil particle size fractions isolated from long-term incubation experiments. Journal of Soil Science, v.36, p.219-229, 1985.

CIHACEK, J.L.; BREMNER, J.M. A simplified ethylene glycol monoethyl ether procedure for assessment of soil surface area. Soil Science Society of America Journal, v.43, p.821-822, 1979. 
CULLINGTON, J.E.; WALKER, A. Rapid biodegradation of diuron and other phenylurea herbicides by a soil bacterium. Soil Biology and Biochemistry, v.31, p.677-686, 1999.

CUPPLES, A.M.; SIMS, G.K.; HULTGREN, R.P.; HART, S.E. Effect of soil conditions on the degradation of cloransulam-methyl. Journal of Environmental Quality, v.29, p.786-794, 2000.

EDWARDS, A.P.; BREMNER, J.M. Microaggregates in soils. Journal of Soil Science, v.18, p.64-73, 1967.

EMPRESA BRASILEIRA DE PESQUISA AGROPECUÁRIA. Sistema brasileiro de classificação de solos. Brasília: EMBRAPA, Produção de Informação, 1999. 412p.

ESPOSITO, E.; PAULILlO, S.M.; MANFIO, G.P. Biodegradation of the herbicide diuron in soil by indigenous actinomycetes. Chemosphere, v.37, p.541-548, 1998 .

EVANKO, C.R.; DZOMBAK, D.A. Influence of structural features on sorption of NOM-analogue organic acids to goethite. Environmental Science and Technology, v.32, p.2846-2855, 1998.

FLINT, J.L.; WITT, W.W. Microbial degradation of imazaquin and imazethapyr. Weed Science, v.45, p.586-591, 1997.

GAILLARDON, P. Influence of soil moisture on long-term sorption of diuron and isoproturon by soil. Pesticide Science, v.47, p.347-354, 1996. 
GAILLARDON, P.; DUR, J.C. Influence of soil moisture on short-term adsorption of diuron and isoproturon by soil. Pesticide Science, v.45, p.297303, 1995.

GILLMAN, G.P. The influence of net charge on water dispersible clay and sorbed sulphate. Australian Journal of Soil Research, v.12, p.173-176, 1974.

GREEN, R.E.; KARICKHOFF, S.W. Sorption estimates for modeling. In: CHENG, H.H. (Ed). Pesticides in the soil environment: process, impacts, and modeling. Madison: Soil Science Society of America, 1990. cap.4, p.79101.

GROVER, R.; SMITH, A.E. Adsorption studies with the acid and dimethylamine forms of 2,4-D and dicamba. Canadian Journal of Soil Science, v.54, p.179186, 1974.

HABERHAUER, G.; PFEIFFER, L.; GERZABEK, M.H. Influence of molecular struture on sorption of phenoxyalkanoic herbicides on soil and its particle size fractions. Journal of Agricultural and Food Chemistry, v.48, p.3722-3727, 2000.

HEILMAN, M.D.; CARTER, D.L.; GONZALES, C.L. The ethylene glycol monoethyl ether (EGME) technique for determining soil-surface area. Soil Science, v.100, p.409-413, 1965.

HELWEG, A. Degradation and adsorption of ${ }^{14} \mathrm{C}-\mathrm{MCPA}$ in soil - Influence of concentration, temperature and moisture content on degradation. Weed Science, v.27, p.287-296, 1987. 
JOHNSON, W.G.; LAVY, T.L.; GBUR, E.E. Sorption, mobility and degradation of triclopyr and 2,4-D on four soils. Weed Science, v.43, p.678-684, 1995.

KALBITZ, K.; GEYER, W.; GEYER, S. Spectroscopic properties of dissolved humic sbstances - A reflection of land use history in a fen area. Biogeochemistry, v.47, p.219-238, 1999.

KARICKHOFF, S.W.; BROWN, D.S. Paraquat sorption as a function of particle size in natural sediments. Journal of Environmental Quality, v.7, p.246-252, 1978.

KHADRANI, A.; SEIGLE-MURANDI， F.; STEIMAN， R.; VROUMSIA, T. Degradation of three phenylurea herbicides (chlortoluron, isoproturon and diuron) by micromycetes isolated from soil. Chemosphere, v.38, p.3041-3050, 1999.

KOSKINEN, W.C.; HARPER, S.S. The retention process: mechanisms. In: CHENG, H.H. (Ed). Pesticides in the soil environment: process, impacts, and modeling. Madison: Soil Science Society of America, 1990. cap.3, p.5177.

KONDA, L.N.; PASZTOR, Z. Environmental distribution of acetochlor, atrazine, chlorpyriphos, and propirochlor under field conditions. Journal of Agricultural and Food Chemistry, v.49, p.3858-3863, 2001.

KRISTENSEN, G.B.; SORENSEN, S.R.; AAMAND, J. Mineralization of 2,4-d, mecoprop, isoproturon and terbuthylazine in a chalk aquifer. Pest Management Science, v.57, p.531-536, 2001. 
LADD, J.N.; PARSONS, J.W.; AMATO, M. Studies of nitrogen immobilization and mineralization in calcareous soils - I. Distribution of immobilized nitrogen amongst soil fractions of different particle size and density. Soil Biology and Biochemistry, v.9, p.309-318, 1977.

LEVY, G.J.; EISENBERG, H.; SHAINBERG, I. Clay dispersion as related to soil properties and water permeabil ity. Soil Science, v.155, p.15-22, 1993.

LUCHINI, L.C. Adsorção-dessorção dos herbicidas paraquat, diuron e 2,4-D em seis solos brasileiros. Piracicaba, 1987. 91p. Dissertação (Mestrado) - Escola Superior de Agricultura "Luiz de Queiroz", Universidade de São Paulo.

MARTIN-NETO, L.; ANDRIULO, A.E.; TRAGHETTA, D.G. Effects of cultivation on ESR spectra of organic matter from soil size fractions of a Mollisol. Soil Science, v.157, p.365-372, 1994.

MEIKLE， R.W.; YOUNGSON， C.R.; HEDLUND， R.T.; GORING， C.A.I.; HAMAKER, J.W.; ADDINGTON, W.W. Measurement and prediction of picloram disappearance rates from soil. Weed Science, v.2, p.549-555, 1973.

MERVOSH, T.L; SIMS, G.K.; STOLLER, E.W. Clomazone fate in soil as affected by microbial activity, temperature, and soil moisture. Journal of Agricultural and Food Chemistry, v.43, p.537-543, 1995.

MILORI, D.M.B.P.; MARTIN-NETO, L.; BAYER, C. Fluorescência induzida por laser para análise da matéria orgânica de solos intactos. São Carlos: EMBRAPA, 2002a. 18 p. (Boletim de Pesquisa e Desenvolvimento, 03). 
MILORI， D.M.B.P.; MARTIN-NETO， L.; BAYER， C.; MIELNICZUK， J.; BAGNATO, V.S. Humification degree of soil humic acids determined by fluorescence spectroscopy. Soil Science, v.167, p.739-749, 2002b.

MONROZIER, L.J.; LADD, J.N.; FITZPATRICK, R.W.; FOSTER, R.C.; RAUPACH, M. Components and microbial biomass content of size fractions in soils of contrasting aggregation. Geoderma, v.50, p.37-62, 1991.

MUSUMECI, M.R.; NAKAGAWA, L.E.; LUCHINI, L.C.; MATALLO, M.B.; ANDREA, M.M. de Degradação do diuron ${ }^{14} \mathrm{C}$ em solo e em plantas de canade-açúcar (Saccharum spp.). Pesquisa Agropecuária Brasileira, v.30, p.775$778,1995$.

NKEDI-KIZZA, P.; RAO, P.S.C.; JOHNSON, J.W. Adsorption of diuron and 2,4,5-T on soil particle-size separates. Journal of Environmental Quality, v.12, p.195-197, 1983.

OADES, J.M. Soil organic matter and structural stability: mechanisms and implications for management. Plant and Soil, v.76, p.319-337, 1984.

OLIVEIRA, J.B.; PRADO, H. Levantamento pedológico semi-detalhado do Estado de São Paulo: quadrícula de Ribeirão Preto. II. Memorial descritivo. Campinas:IAC, 1987. 133p.(IAC. Boletim Científico, 7).

PRESTON, C.M. Applications of NMR to soil organic matter analysis: history and prospects. Soil Science, v.161, p.144-166, 1996. 
PRADO, A.G.S.; VIEIRA, E.M.; REZENDE, M.O.D. Monitoring of the harmful concentrations of 2,4-dichlorophenoxyacetic acid (2,4-d) in soils with and without organic matter. Journal of the Brazilian Chemical Society, v.12, p.485-488, 2001.

RAIJ, B. van Fertilidade do solo e adubação. Campinas:Editora Agronômica Ceres/Potafos, 1991. 343p.

RAIJ, B. van; SILVA, N.M.; BATAGLIA, O.C.; QUAGGIO, J.A.; HIROCE，R.; CANTARELLA, H.; JUNIOR, R.B.; DECHEN, A.R.; TRANI, P.E. Recomendações de adubação e calagem para o Estado de São Paulo. Campinas: IAC, 1985. 107p. (IAC. Boletim Técnico, 100).

RATNER-ZOHAR, Y.; BANIN, A.; CHEN, Y. Oven drying as a pretreatment for surface-area determinations of soils and clays. Soil Science Society of America Journal, v.47, p.1056-1058, 1983.

REGITANO, J.B.; BISCHOFF, M.; LEE, L.S.; REICHERT, J.M.; TURCO, R.F. Retention of imazaquin in soil. Environmental Toxicology and Chemistry, v.16, p.397-404, 1997.

RISTORI, G.G.; SPARVOLI, E.; NOBILI, M. de; D’ACQUI, L.P. Characterization of organic matter in particle-size fractions of Vertisols. Geoderma, v.54, p.295-305, 1992.

ROCHA, W.S.D. da. Sorção de imazaquin em Latossolos ácricos. Piracicaba, 1999. 59p. Dissertação (Mestrado) - Escola Superior de Agricultura "Luiz de Queiroz", Universidade de São Paulo. 
ROCHA, W.S.D.; ALLEONI, L.R.F.; REGITANO, J.B.; CASAGRANDE, J.C.; TORNISIELLO, V.L. Influência do $\mathrm{pH}$ na sorção de imazaquin em um Latossolo Vermelho acriférrico. Revista Brasileira de Ciência do Solo, v. 24, p.649-655, 2000.

ROCHA, W.S.D.; REGITANO, J.B.; ALLEONI, L.R.F.; TORNISIELO, V.L. Sorption of imazaquin in soils with positive balance of charges. Chemosphere, v.49, p.263-270, 2002.

RODRIGUES, B.N.; ALMEIDA, F.S. de Guia de herbicidas. 3.ed. Londrina, 1995. 675p.

ROY, C.; GAILLARDON, P.; MONTFORT, F. The effect of soil moisture content on the sorption of five sterol biosynthesis inhibiting fungicides as a function of their physicochemical properties. Pest Management Science, v.56, p.795-803, 2000.

SAKURAI, K.; OHDATE, Y.; KYUMA, K. Factors affecting zero point of charge (ZPC) of variable charge soils. Soil Science and Plant Nutrition, v.35, p.21-31, 1989.

SCHULTEN, H.R.; LEINWEBER, P. New insights into organic-mineral particles: composition, properties and models of molecular structure. Biology and Fertility of Soils, v.30, p.399-432, 2000.

SCHUZ, N. Comparison of spray drift and runoff related input of azinphosmethyl and endosulfan from fruit orchards into the Lourens river, South Afric. Chemosphere, v.45, p.543-551, 2001. 
SENESI, N. Application of electron spin resonance (ESR) spectroscopy in soil chemistry. Advances in Soil Science, v.14, p.77-130, 1990.

SHEETS, T.J. Review of disappearance of substituted urea herbicides from soil. Journal of Agricultural and Food Chemistry, v.12, p.30-33, 1964.

SPARLING, G.P.; CHESHIRE, M.V. Effect of periodate oxidation on the polysacaccharide content and microaggregate stability of rhizosphere and nonrhizosphere soils. Plant and Soil, v.88, p.113-122, 1985.

STOUT, J.D.; GOH, K.M.; RAFTER, T.A. Chemistry and turnover of naturally occurring resistant organic compounds in soil. In: PAUL, E.A.; LADD, J.N. (Ed.). Soil biochemistry. New York: Marcel Dekker, 1985. p.1-73.

TARCHITZKY, J.; HATCHER, P.G.; CHEN, Y. Properties and distribution of humic substances and inorganic structure-stabilizing components in particlesize fractions of cultivated mediterranean soils. Soil Science, v.165, p.328-342, 2000.

THIRUNARAYANAN， K.; ZIMDAHL， R.L.; SMIKA， D.E. Chlorsulfuron adsorption and degradation in soil. Weed Science, v.33, p.558-563, 1985.

TISDALE, S.L.; NELSON, W.L.; BEATON, J.D.; HAVLIN, J.L. Soil fertility and fertilizers . New York: Macmillan Publishing Company, 1993.

TISDALL, J.M.; OADES, J.M. Organic matter and water-stable aggregates in soils. Journal of Soil Science, v.33, p.141-163, 1982. 
TURCHENEK, L.W.; OADES, J.M. Fractionation of organo-mineral complexes by sedimentation and density techniques. Geoderma, v.21, p.311-343, 1979.

UEHARA, G. Acric properties and their significance to soil classification. In: INTERNATIONAL SOIL CLASSIFICATION WORKSHOP， 8., Rio de Janeiro, 1986. Proceedings. Rio de Janeiro: Embrapa, SNLCS, 1988. p.19-22.

VEEH, R.H.; INSKEEP, W.P.; CAMPER, A.K. Soil depth and temperature effects on microbial degradation of 2,4-D. Journal of Environmental Quality, v.25, p.5-12, 1996.

YU, T.R. Chemistry of variable charge soil. New York: Oxford University Press, 1997. 505p.

ZIMDAHL, R.L.; GWYNN, S.M. Soil degradation of three dinitroanilines. Weed Science, v.25, p.247-251, 1977.

ZSOLNAY, A.; HAIGAR, F.; JIMENEZ, M.; STEINWEG, B.; SACCOMANDI, F. Differentiating with fluorescence spectroscopy the sources of dissolved organic matter in soils subjected to drying. Chemosphere, v.38, p.45-50, 1999. 